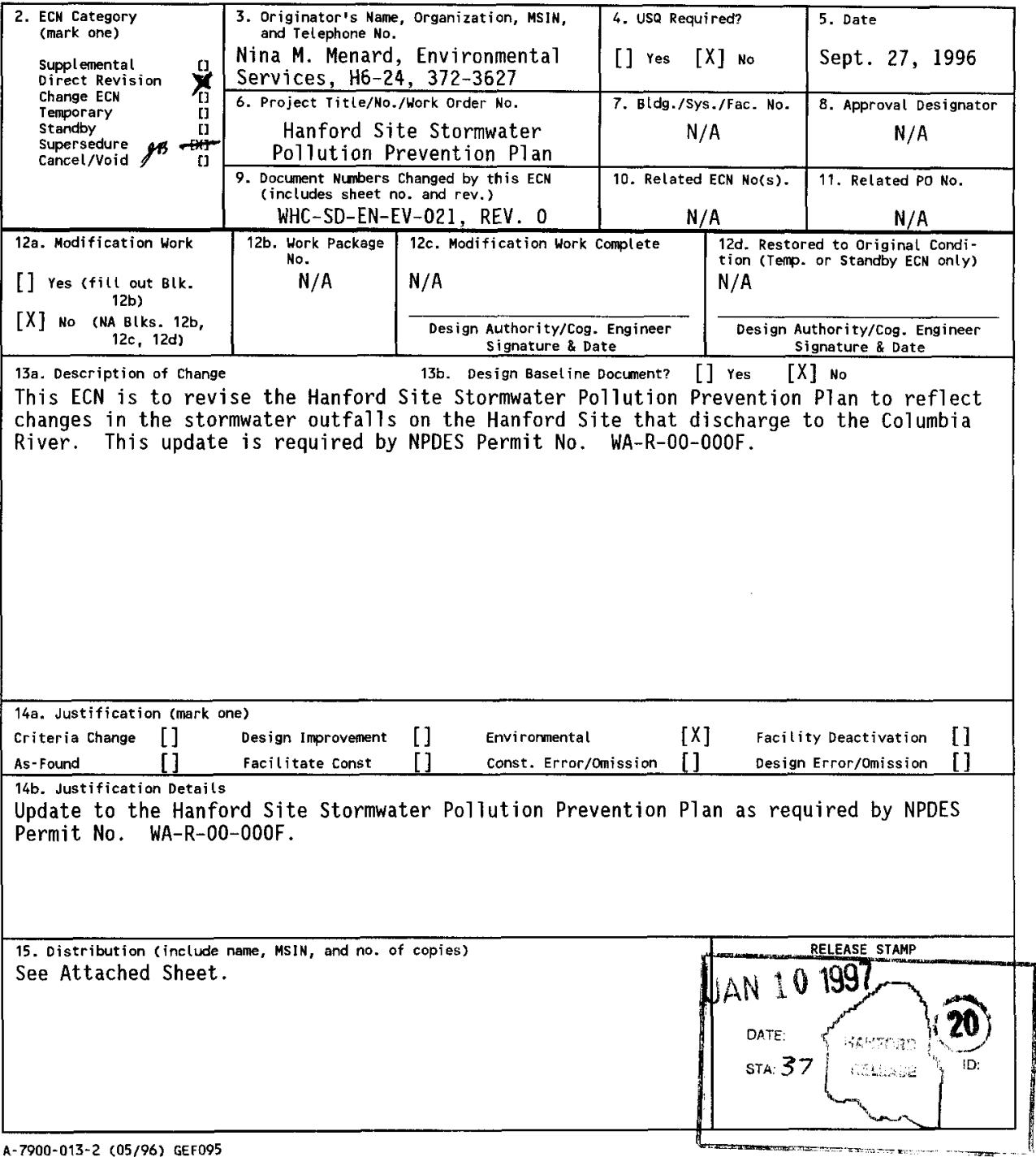




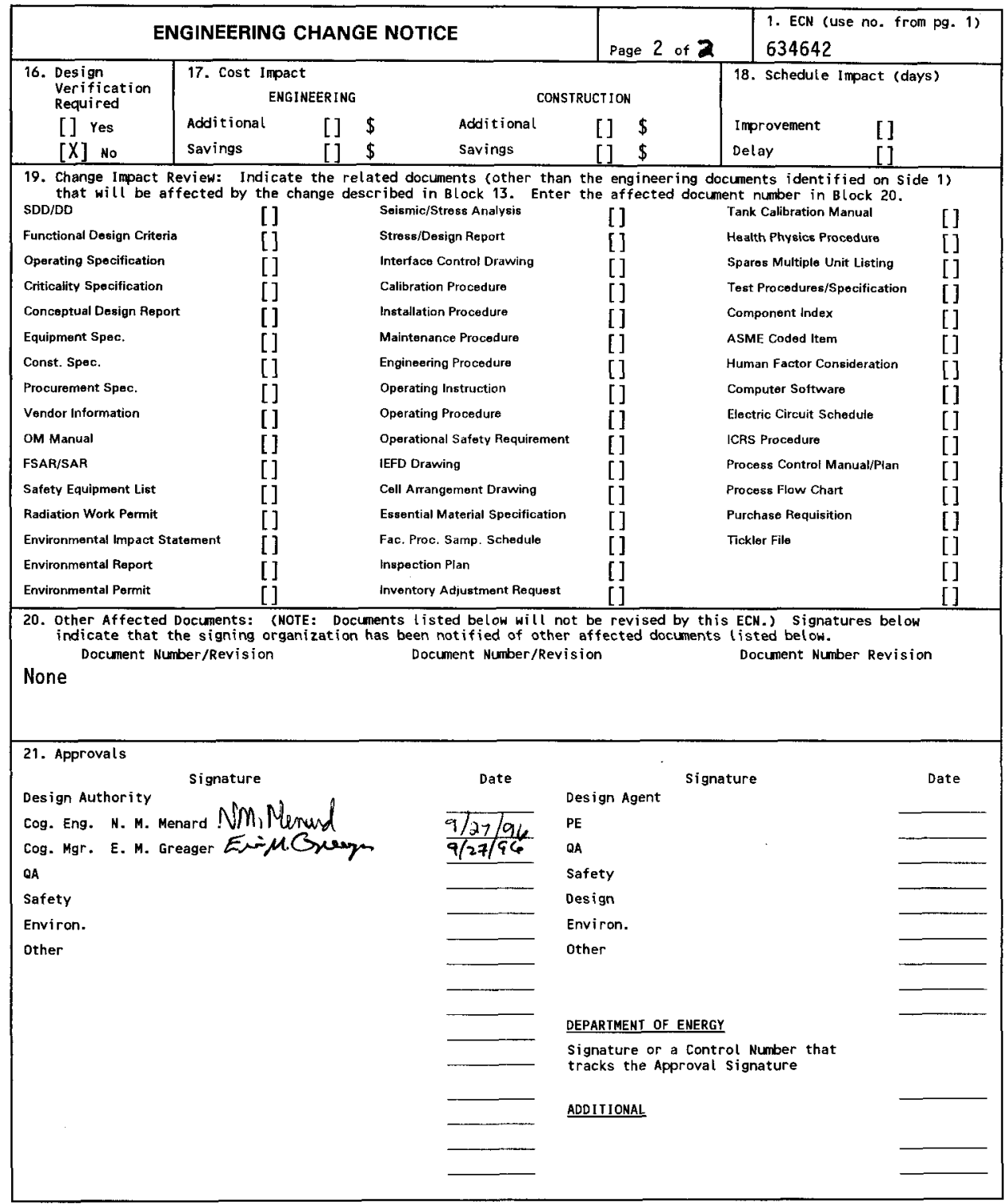




\title{
Hanford Site Stormwater Pollution Prevention Plan
}

\author{
Nina M. Menard
}

Westinghouse Hanford Company, Richland, WA 99352

U.S. Department of Energy Contract DE-AC06-87RL10930

$\begin{array}{lll}\text { EDT/ECN: } 634642 & \text { UC: } 7000 \\ \text { Org Code: } 01842 & \text { Charge Code: R1015 } \\ \text { B\&R Code: } & \text { EW } 3110010 \text { Total Pages: }-136-135\end{array}$

Key Words: Stormwater, Stormwater Pollution Prevention Plan, Hanford Site Stormwater Pollution Prevention Plan, Storm Water, SWPPP, NPDES, Outfalls, Stormwater Outfalls.

Abstract: This ECN is to replace and update the Hanford Site Stormwater Pollution Prevention Plan as required by NPDES Permit No. WA-R-10-000F.

TRADEMARK DISCLAIMER. Reference herein to any specific commercial product, process, or service by trade name, trademark, manufacturer, or otherwise, does not necessarily constitute or imply its endorsenent, recommendation, or favoring by the United States Government or any agency thereof or its contractors or subcontractors.

Printed in the United States of America. To obtain copies of this document, contact: WHC/BCS Document Control Services, P.O. Box 1970, Mailstop H6-08, Richland WA 99352, Phone (509) 372-2420; Fax (509) 376-4989.
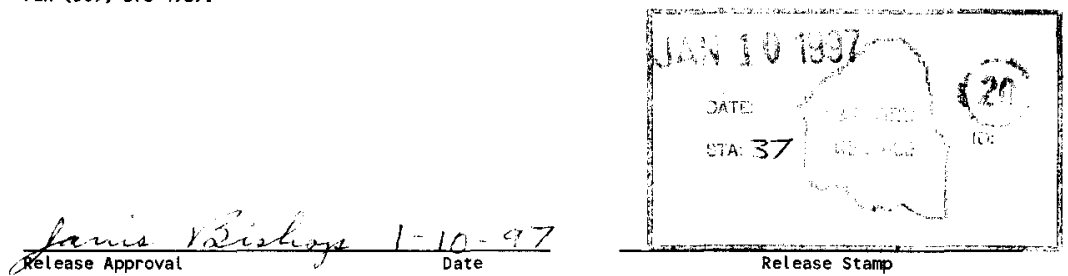

\section{Approved for Public Release}


RECORD OF REVISION

(1) Document Number

WHC-SD-EN-EV-021

Page 1

(2) Title

Hanford Site Stormwater Pollution Prevention Plan

CHANGE CONTROL RECORD

(3) Revision (4) Description of Change - Replace, Add, and Delete Pages O EDT-142539,8/70/93

1 RS (7) Replace entire document. ECN No. 634642

Authorized for Release

(5) Cog. Engr. (6) Cog. Mgr. Date

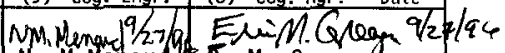

N. M. Menard E. M. Greaget

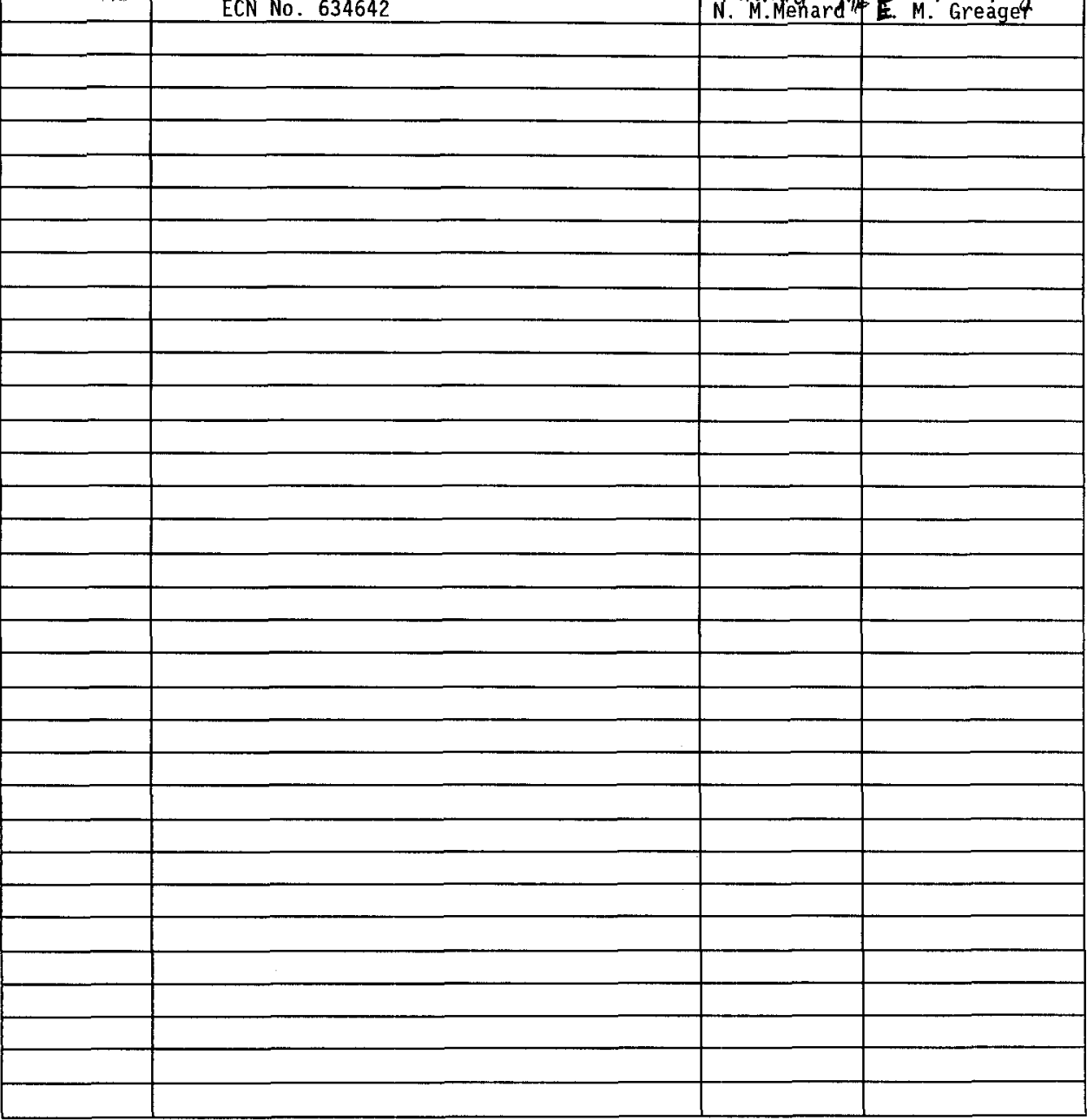


WHC-SD-EN-EV-021

Revision 1

\section{Hanford Site Stormwater Pollution Prevention Plan}




\section{WHC-SD-EN-EV-021, ReV. 1 \\ HANFORD SITE STORMWATER POLLUTION PREVENTION PLAN \\ Certification}

I certify under penalty of law that this document and all attachments were prepared under my direction or supervision in accordance with a system designed to assure that qualified personnel properly gather and evaluate the information submitted. Based on my inquiry of the person or persons who manage the system, or those persons directly responsible for gathering information, the information submitted is, to the best of my knowledge and belief, true, accurate, and complete. I am aware that there are significant penalties for submitting false information, including the possibility of fine and imprisonment for knowing violations.

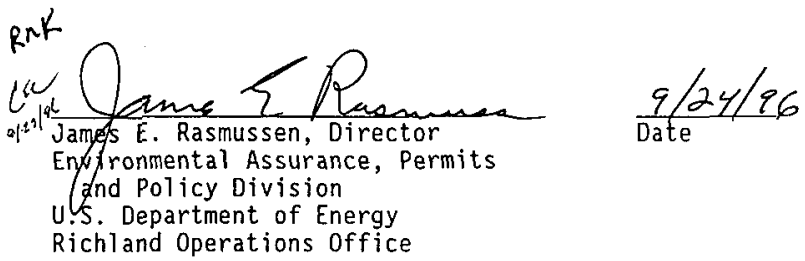


WHC-SD-EN-EV-021, Rev. 1

CONTENTS

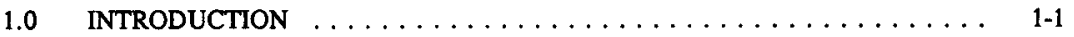

1.1 PURPOSE OF THE STORMWATER POLLUTION PREVENTION PLAN 1-1

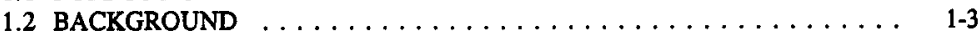

1.2.1 Historical Overview of Hanford Site Industrial Activities . . . . . 1-3

1.2.2 Regulatory Background of Stormwater Discharge .......... 1-3

1.3 ORGANIZATION OF DOCUMENT $\ldots \ldots \ldots \ldots \ldots \ldots \ldots \ldots \ldots \ldots$

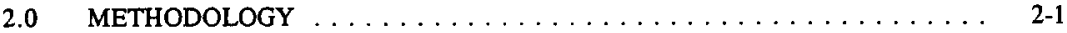

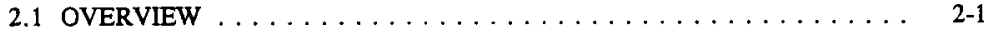

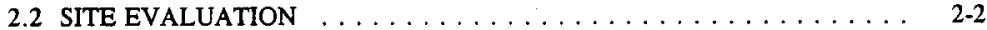

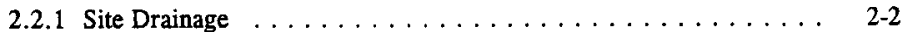

2.2.2 General Field Survey Findings . . . . . . . . . . . . . 2 2-3

$2.2 .3100-\mathrm{B}$ and $100-\mathrm{C}$ Area Field Survey Findings $\ldots \ldots \ldots . \ldots . . \ldots 2-4$

2.2.4 100-D and 100-DR Area Field Survey Findings . . . . . . . . . 2-4

2.2.5 100-F Area Field Survey Findings . . . . . . . . . . . . 2-4

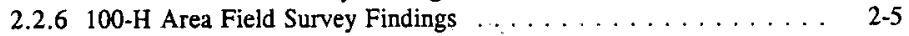

2.2.7 100-K Area Field Survey Findings $\ldots \ldots \ldots \ldots \ldots . \ldots \ldots$

$2.2 .8100-\mathrm{N}$ Area Field Survey Findings $\ldots \ldots \ldots \ldots . \ldots \ldots$

2.2 .9300 Area Field Survey Findings $\ldots \ldots \ldots \ldots$ 2-7 . . . . . . .

3.0 STORMWATER POLLUTION PREVENTION PLAN DESCRIPTION . . . . . 3-1

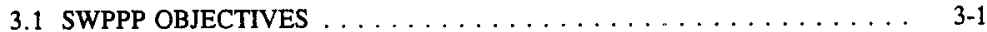

3.2 STORMWATER POLLUTION PREVENTION TEAM . . . . . . . . . $3-1$

3.3 SITE MAPS ... . . . . . . . . . . . . . . . . . 3-2

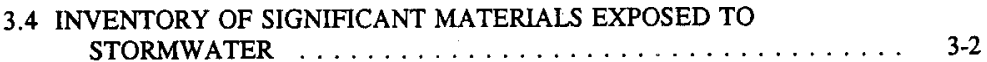

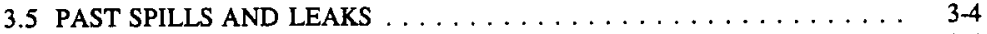

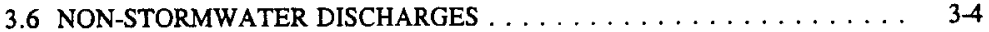

3.7 STORMWATER MONITORING DATA $\ldots \ldots \ldots \ldots \ldots \ldots \ldots \ldots$

3.8 SUMMARY OF POTENTIAL POLLUTANT SOURCES AND RISKS $\ldots$. 3-5

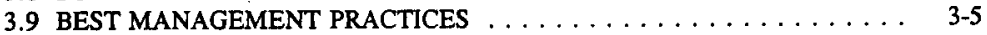

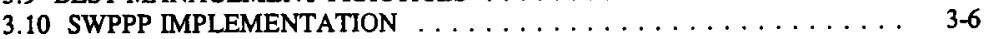

3.11 COMPREHENSIVE SITE COMPLIANCE EVALUATIONS $\ldots \ldots \ldots \ldots$. $\ldots$ 3-8

$4.0 \quad$ REFERENCES $\ldots \ldots \ldots \ldots \ldots \ldots \ldots \ldots \ldots \ldots \ldots \ldots \ldots \ldots$

\section{APPENDICES:}

A - Stormwater Outfall Maps

B - Outfall Description Tables

C - Hanford Site List of Significant Spills and Leaks

D - Status Report on Implementation of Hanford Site SWPPP

E - Justifications for Outfall Elimination from the SWPPP

F - Stormwater General Permit Coverage Notice

G - EPCRA Certification 


\section{WHC-SD-EN-EV-021, Rev. 1}

\section{CONTENTS (Cont.)}

\section{FIGURES}

1. Hanford Site Drainage Map . . . . . . . . . . (See Figure Pocket)

\section{TABLES}

3-1. Existing Stormwater Runoff Related BMP's . . . . . . . . . . . . . 3-7 
WHC-SD-EN-EV-021，Rev. 1

\section{ACRONYMS}

$\begin{array}{ll}\text { BMP } & \text { best management practice } \\ \text { CERCLA } & \text { Comprehensive Environmental Response, Compensation, and Liability Act of } \\ 1980 & \\ \text { CFR } & \text { Code of Federal Regulations } \\ \text { CWA } & \text { Clean Water Act } \\ \text { DOE } & \text { U.S. Department of Energy } \\ \text { DOE-RL } & \text { U.S. Department of Energy-Richland Operations Office } \\ \text { EPA } & \text { U.S. Environmental Protection Agency } \\ \text { ERDA } & \text { Energy Research and Development Agency } \\ \text { FR } & \text { Federal Register } \\ \text { FWPCA } & \text { Federal Water Pollution Control Act } \\ \text { ICF KH } & \text { ICF Kaiser Hanford Company } \\ \text { NOI } & \text { Notice of Intent } \\ \text { NPDES } & \text { National Pollutant Discharge Elimination System } \\ \text { PPT } & \text { Pollution Prevention Team } \\ \text { PNL } & \text { Pacific Northwest Laboratories } \\ \text { RCRA } & \text { Resource Conservation and Recovery Act of 1976 } \\ \text { SIC } & \text { Standard Industrial Classification } \\ \text { SWCSCE } & \text { Storm Water Comprehensive Site Compliance Evaluations } \\ \text { SWPPP } & \text { Storm Water Pollution Prevention Plan } \\ \text { WHC } & \text { Westinghouse Hanford Company }\end{array}$


WHC-SD-EN-EV-021, Rev. 1

\subsection{INTRODUCTION}

\subsection{PURPOSE OF THE STORMWATER POLLUTION PREVENTION PLAN}

The Hanford Site has numerous facility areas within its boundary which conduct certain industrial activities subject to federal National Pollutant Discharge Elimination System (NPDES) industrial stormwater discharge permit regulations under the jurisdiction of the U.S.

Environmental Protection Agency (EPA) [Federal Register (FR) 1990 and 1992; Code of Federal Regulations (CFR) 1991]. The regulations govern the control of pollutants in "stormwater associated with industrial activity." As defined in the regulations (CFR 1991), "stormwater associated with industrial activity" means the point source discharge of stormwater runoff from any conveyance which is used for collecting and conveying stormwater and which is directly related to manufacturing, processing, or raw materials storage areas at an industrial facility. Categories of industrial facilities within the Hanford Site subject to the NPDES industrial stormwater regulations include:

- $\quad$ Facilities with Standard Industrial Classification (SIC) code 28 for chemical and allied products; SIC code 37 for transportation equipment; and SIC code 41 for local and suburban transit and interurban highway and passenger transportation;

- Hazardous waste treatment, storage, or disposal facilities, including those that are operating under interim status or a permit under Subtitle $C$ of RCRA;

- Landfills, land application sites, and open dumps (active, inactive, or closed) that receive or have received industrial wastes and that are subject to regulation under Subtitle D of RCRA;

- Steam electrical power generating facilities, including coal handling sites;

- Certain transportation facilities which have vehicle maintenance shops and equipment cleaning operations; and

- Construction activities including clearing, grading, and excavation activities involving five acres or more in land area.

To initiate compliance with the NPDES industrial stormwater discharge permit regulations, the DOE initiated actions to obtain site coverage under an NPDES General Permit, which involved the following steps:

- $\quad$ Filing a Notice of Intent (NOI) application to obtain coverage under an NPDES general permit for stormwater discharges associated with industrial activity. NPDES industrial stormwater discharge permit regulations have stipulated that an industrial facility subject to regulation and commencing operations prior to October 1, 1992, must submit an NOI application to the EPA on or before October 1, 1992. The DOE filed a NOI application with the EPA on October 1, 1992 to obtain coverage under NPDES General Permit No. WA-R-00-000F. This general permit was issued by EPA on September 9, 1992 for owners and operators of federal facilities in Washington State engaged in discharging 
stormwater associated with industrial activities (FR 1992). September 9, 1992 is considered the effective issuance date of NPDES General Permit No. WA-R-00-000F. This general permit expires on September 9, 1997. On February 14, 1994, EPA issued coverage notice and assigned WA-R00-A17F as the Hanford Site's NPDES stormwater permit number. The Stormwater General Permit Coverage Notice for the Hanford Site is included in Appendix F.

- Development and implementation of an industrial stormwater pollution prevention plan (SWPPP). NPDES industrial stormwater discharge permit regulations (CFR 1991 and FR 1992) have stipulated that an industrial facility subject to regulation and in operation on or before October 1, 1992 must develop a SWPPP by April 1, 1993, and provide for implementation and compliance with the terms of the SWPPP on or before October 1, 1993.

The Hanford Site Stormwater Pollution Prevention Plan (SWPPP) (WHC, 1993) was certified by J.D. Wagoner, Manager, DOE-RL, on April 1, 1993, in compliance with the general permit. After April 1, 1993 the SWPPP was reviewed and evaluated by a site wide pollution prevention team to implement the SWPPP by October 1, 1993 (see Sections 3.2, 3.10, and 3.11). As required by General Permit No. WA-R-00-000F (WA-R-00-A17F) Section IV, Part D, Section 4.c, an annual report must be developed by RL and retained on site to verify that requirements listed in General Permit WA-R-00-000F (WA-R-00-A17F) are being implemented. The Hanford Site Stormwater Comprehensive Site Compliance Evaluation Report (WHC 1994, 1995) fulfills this requirement and contains the results of inspections of the storm water outfalls listed in the SWPPP (WHC 1993). If an industrial facility located within a Hanford Site facility area uses and/or stores federal Emergency Planning and Community Right-to-Know Act (EPCRA) Section 313 water priority chemicals after April 1, 1993, then the SWPPP for such a facility must be reviewed, evaluated and certified by a Registered Professional Engineer in order to incorporate SWPPP modifications addressing special NPDES General Permit requirements for monitoring, reporting, training, and preventive maintenance practices at EPCRA 313 facilities. (EPCRA Recertification must take place every three years thereafter, or as soon as possible after significant modifications are made to a facility or facilities within the Hanford Site.) An EPCRA review has been completed (see Section 3.4). As required, copies of this SWPPP are maintained on-site, and are available for review by the EPA.

A Hanford Site SWPPP for construction activities has not been included in this document since these activities are addressed separately from industrial activities under NPDES industrial stormwater discharge permit regulations. Separate and specific guidance for developing and implementing SWPPPs for construction activities has been prepared by EPA.

This revision of the SWPPP addresses all potential pollution to the Columbia and Yakima Rivers that might occur as a result of stormwater runoff, as identified during initial site field surveys conducted in February and March of 1993 and the annual surveys conducted in 1994 and 1995. The annual surveys referred to as Storm Water Comprehensive Site Compliance Evaluations (SWCSCEs) are documented in WHC $(1994,1995)$ and were used to update this revision of the SWPPP. Continued operation of the Hanford Site will require periodic revisions to the SWPPP by the site pollution prevention team(s). The SWPPP must be updated and modified periodically in order for the Hanford Site to remain current and in compliance with the regulatory requirements. 
WHC-SD-EN-EV-021, Rev. 1

\subsection{BACKGROUND}

\subsubsection{Historical Overview of Hanford Site Industrial Activities}

In 1943, the U.S. Department of the Army, Corps of Engineers constructed the world's first plutonium production nuclear reactor (the 100-B reactor) on the Hanford Site, an area of about 560 square miles of arid, desert land in southeastern Washington State (Figure 1). By April 1945, the Hanford Site began to diversify its industrial activities by housing three more single-purpose (plutonium production) nuclear reactors (the 100 Areas), and other facilities for the entire nuclear cycle, including nuclear fuel fabrication facilities (the 300 Area), three chemical processing plants (the 200 Areas), five coal-fired electrical powerplants, and other support facilities. By the 1950's, eight single-purpose, nuclear reactors had been built in the 100 Areas, and were producing plutonium. N-Reactor began weapon materials production in 1963 . By 1964 , a total of nine nuclear reactors were operating at the Hanford Site. The eight singlepurpose, plutonium production reactors were shut down between 1964 and 1971. The production of new plutonium stopped at the Hanford Site in 1987 when the dual-purpose, 100-N reactor was shut down (DOE 1991).

By 1975 , energy research had become the major focus at the Hanford Site. The future use of such energy sources as nuclear, solar, geothermal, fossil, wind, and organic waste were investigated. In the early 1980 's, the role of the Hanford Site re-emphasized defense chemical processing and waste management activities. Since 1989, the focus of the Hanford Site has shifted again to address the cleanup and remediation of its nuclear and chemical wastes. In May 1989, DOE, EPA, and the Washington State Department of Ecology (Ecology) signed the Hanford Federal Facility Agreement and Consent Order (Ecology et al. 1991), the Site's cleanup blueprint. The Agreement as subsequently revised lays out a 30-year timetable to achieve one of the largest environmental restoration projects in history. The Environmental Restoration and Waste Management Site-Specific Plan for the Richland Operations Office - Hanford Site Five-Year Plan Fiscal Years 1993-1997 (DOE-RL 1991) supports and goes beyond the Agreement. The plan outlines waste cleanup activities proposed for the Hanford Site through the 1997 fiscal year and is updated annually.

The Hanford Site facilities were operated by the U.S. Atomic Energy Commission from 1947 to 1974 and by its successors, the U.S. Energy Research and Development Administration (ERDA) from 1974 to 1977, and the DOE since 1977 (DOE 1991).

\subsubsection{Regulatory Background of Stormwater Discharge}

The 1972 amendments to the federal Water Pollution Control Act (FWPCA) prohibit the point source discharge of any pollutant to a surface water body unless the discharge is authorized by an NPDES permit. An NPDES permit specifies monitoring, reporting and control requirements, including control on limits of pollutants in discharges. In 40 CFR Part 122.2 (CFR 1991), a point source is defined as any discernible, confined, and discrete conveyance, including but not limited to, any pipe, ditch, channel, tunnel, conduit, well, discrete fissure, container, rolling stock, concentrated animal feeding operation, landfill leachate collection system, vessel, or other floating craft from which pollutants are or may be discharged. The term does not include return flows from irrigated agriculture or agricultural stormwater runoff.

Historically, NPDES permits have focused on regulating point source discharges of:

- Industrial process and municipal wastewater treatment plant effluent, and 
- Stormwater runoff from certain industrial categories with stormwater effluent limitations identified in 40 CFR, Parts 400-471 (Subchapter N).

However, as pollution control measures were installed for these types of discharges, it was becoming more evident that more non-point, diffuse sources (occurring over a wide area) of water pollution were also major causes of water quality problems. Historically, stormwater runoff (rainfall and snow melt runoff) has been considered only to be diffuse, or non-point source pollution (Berman et al. 1991). Nevertheless, as stormwater runoff drains from streets, parking lots, industrial and construction sites, and mining, logging, and agricultural areas, pollutants are discharged by gravity flow through a variety of natural or man-made conveyances, which have been considered point sources under the CWA. As stormwater runoff discharges into a variety of drainage facilities, i.e., detention/retention basins, it may scour accumulated pollutants along its path. The polluted runoff often ends up in surface water bodies such as creeks, streams, rivers, lakes, estuaries, bays, and oceans.

In 1987, the CWA was amended [by adding Section 402(p)] to establish phased NPDES industrial stormwater discharge permit application requirements. A 1990 National Water Quality Inventory Report to Congress, based on biennial reports submitted by the States under Section 305(b) of the CWA, indicated that roughly 30 percent of identified cases of water quality impairment to waters are attributed to point source discharges of stormwater runoff. Moreover, studies have shown that stormwater runoff from urban and industrial areas typically contains significant quantities of the same general types of pollutants that are found in industrial process and wastewater treatment plant effluent, causing similar adverse impacts to both the ecological and human health environments. Thus, recognizing the adverse impacts of point source discharges of stormwater runoff into our nation's surface water bodies, the EPA issued regulations on November 16, 1990 (FR 1990 and CFR 1991) establishing initial NPDES permit application requirements for stormwater discharges associated with certain industrial activities, and municipal separate storm sewer systems serving populations of 100,000 or more.

Important updates for NPDES industrial stormwater discharge permitting regulations were issued by EPA on September 9, 1992, whereby NPDES General Permits for industrial activities were promulgated for 12 states and 6 territories without authorized NPDES permit programs (FR 1992). As mentioned in Section 1.1, NPDES General Permit No. WA-R-00-000F was issued by EPA on September 9, 1992 for federal facilities located in Washington State. In order to have the Hanford Site comply with and obtain coverage under this NPDES General Permit, the DOE was required to file an NOI application, and develop and implement a SWPPP, as previously discussed in Section 1.1. 
WHC-SD-EN-EV-021, Rev. 1

\subsection{ORGANIZATION OF DOCUMENT}

This SWPPP is divided into 3 primary sections with supplementary appendices:

- Section 1.0, "Introduction," describes the purpose and regulatory background for the SWPPP.

- Section 2.0, "Methodology," presents the approach to developing the SWPPP, including a description of the site drainage evaluation and site surveys.

- Section 3.0, "Stormwater Pollution Prevention Plan Description, " presents the various sitewide components of the SWPPP.

- Section 4.0, "References," lists the references cited in this SWPPP.

- Appendix A includes the Stormwater Outfall Maps.

- Appendix B contains the Individual Outfall Descriptions and Current Status.

- Appendix C contains the Hanford Site List of Significant Spills and Leaks.

- Appendix D contains the "Status Report on Implementation of Hanford Site SWPPP".

- Appendix E contains Justifications for Outfall Elimination from the SWPPP.

- Appendix F contains the Stormwater General Permit Coverage Notice. 
WHC-SD-EN-EV-021, Rev. 1

\subsection{METHODOLOGY}

\subsection{OV.ERVIEW}

The methodology employed to develop the baseline site-wide SWPPP (WHC 1993) first required the identification of industrial facilities within the Hanford Site that could potentially discharge pollution to the Columbia or Yakima Rivers via stormwater runoff. This initial phase included an evaluation of site-wide and area-specific topographic maps to determine regional drainage patterns and identify those industrial facilities within the Hanford Site from which surface drainage could reach the Columbia or Yakima Rivers. Once these facilities were identified, field surveys were initiated for each facility.

The field surveys were conducted initially to identify all potential discharge points or outfalls to the Columbia River. The Yakima River was excluded from further consideration since industrial stormwater runoff cannot reach it (see Section 2.2.1). The potential discharge points and/or outfalls included point source conveyances such as drainpipes, culverts, exposed ditches, and industrially-related topographic depressions. Once the conveyances were identified, additional "walkdowns" were conducted to determine the potential surface drainage area to those conveyances and to identify any potential pollution sources or high-risk waste generating areas or activities that could potentially come into contact with stormwater runoff.

If potential pollution sources were identified, the site was further assessed to determine if any existing structural Best Management Practices (BMPs) were in place, such as flow diversion structures, retention/detention ponds, vegetative swales, berms, or sediment traps. The individual sites were further assessed for evidence of spills or leaks, the degree to which the pollution sources were exposed to the elements, compatibility of existing storage or containment, potential for exposure to runoff, and general housekeeping. Photographs were taken for documentation purposes, and all data were recorded on field survey sheets. Wherever possible, engineering and topographic data were checked to verify field observations. The data were then used to develop area-specific data packages, and BMPs.

In conjunction with the field surveys, a database and literature search was conducted to develop supporting background data required for the SWPPP. This supporting data included materials inventories, spill control plans, records of previous spills and leaks, and any existing stormwater discharge sampling data for the facilities of concern. The quality and quantity of available data varied, depending on the type of data and the facility. Wherever appropriate data were available, they were incorporated into the data package for each respective facility. Representative data sources for both site-wide and facility-specific data include the 1991 Tier Two Emergency and Hazardous Chemical Inventory (DOE-RL 1992), the WHC Effluent Report for 300, 400, and 1100 Area Operations for Calendar Year 1989 (WHC 1990), the Environmenta! Compliance Manual (WHC 1991), and various chemical spill control plans for the 300 Area (Duffield 1991), the 100 Areas (Chien 1989), the 400 Area (McKarns 1991), the 700 Area (Haggard 1992a), the 1100 Area (Haggard 1991), and the 300 Area (Haggard 1992b). 
WHC-SI)-EN-EV-021, Rev. 1

\subsection{SITE EVALUATION}

The following sections describe the process by which those sites with the potential to discharge pollution to the Columbia River via stormwater runoff were identified and evaluated in the baseline SWPPP (WHC 1993) and it describes changes in status of individual outfalls for each area based upon annual SWCSCEs that were conducted in 1994 and 1995 and for this revision to the SWPPP.

\subsubsection{Site Drainage}

The primary goal of the SWPPP, as described earlier in Section 1, is to identify potential sources of pollution at each industrial facility within the Hanford Site that could be conveyed to the Columbia or Yakima Rivers by stormwater runoff and associated conveyance systems, and to determine BMPs to prevent this pollution from entering a river. To accomplish this, it was first necessary to define the surface drainage of the site in order to identify areas with the potential to convey stormwater runoff to the Columbia or Yakima Rivers.

Figure 1 (see pocket) is a site-wide topographic map with a 6-m (20-ft) contour interval. This figure illustrates the primary features which control regional surface drainage on the Hanford Site. These primary features include the Rattlesnake Hills, the Cold Creek Valley, and Gable Mountain. The Hanford Site 200 Areas are located on a central plateau located between the Rattlesnake Hills and Gable Mountain, just northeast of the Cold Creek Valley. Regional surface drainage from the 200 Areas is to the Cold Creek Valley to the southwest (indicated by the dark line on the eastern margin of the Cold Creek Valley), and to the west and southeast from Gable Mountain. North of the drainage boundary formed by Gable Mountain (also indicated by a dark line), all regional surface drainage is northwest to northeast towards the Columbia River. However, there are no industrial facilities situated between the 100 Areas and Gable Mountain. All regional surface drainage along the eastern margin of the site is generally towards the Columbia River.

Facilities within the 200 Areas are either below grade, terraced and surrounded by berms and ditches, or a combination of these features. Both 200 Areas were observed to have perimeter roads that have substantial ditches on either side of the roads. These ditches, combined with the below grade and bermed features prevent stormwater runoff from exiting the areas and entering the Cold Creek floodplain boundary to the southwest, even in the event of the 100 year flood (DOE 1987). Since the Cold Creek Valley would be the most direct drainage pathway to the Yakima River, it is therefore unlikely that stormwater run-off would ever reach this river. As a result, the Yakima River was excluded from further consideration in the baseline SWPPP (WHC 1993).

The Hanford Site 400 Area is located on a large plain with broken terrain features and localized low spots such that runoff from an extreme precipitation event would be locally retained where it would infiltrate, and could not be conveyed far from the 400 Area perimeter.

Washington Public Power Supply System (WPPSS) facilities have been excluded from consideration, since they are currently permitted under WNP-2 NPDES Permit No. WA-0025151, which was renewed on September 10, 1990 for five years. NPDES Permit No. WA-0025151 was issued on October 9, 1995 by the Energy Facility Site Evaluation Council. Stormwater considerations for WPPSS facilities are addressed under this permit. 
The Hanford Site 1100 and 3000 Areas were studied using the 1:500 and 1:50 scale "Topographic maps of the 1100-EM-1 Operable Unit", prepared by Degross Aerial Mapping (1189). The topographic maps indicated that Stevens Drive is 3 to 4 feet higher in elevation than the 1100 Area and general drainage occurring from a maximum precipitation event would be contained between the railroad track berm and Stevens Drive. The drainage for the 1100 Area would be to the natural depression features just north and just south of the site, where it would be effectively contained within the 1100 Area. The 3000 Area drainage is generally to the north where a ditch intercepts and routes the flow to the east to a large depression east of the site. This feature drains to natural depressions to the south where run-off would be contained from further conveyance. Field checks also verified that no potential pollution sources or conveyances could be found along the Columbia River behind areas such as the Battelle Sigma V building. Access to Port of Benton facilities was not possible during the time the initial site surveys were conducted.

Finally, previous water balance studies (PNL 1989, 1990) at the Hanford Site have suggested that surface runoff is negligible and that surface conveyance for any significant distance does not occur. Even under an extreme precipitation event such as a heavy snow fall followed by a rapid melt on frozen soil, significant conveyance would be likely only on terrain with moderate slope. Since the majority of the facilities at the Hanford Site are all on flat, terraced, or very gentle sloped plateaus, no runoff would be expected to reach the Columbia River from these areas, except for those facilities adjacent to the Columbia River.

The results of this evaluation indicate that the only industrial facility areas on the Hanford Site with the potential for stormwater run-off to reach either river are the seven facility areas adjacent to the Columbia River. These include 100-B and 100-C, 100-K, 100-N, 100-D and 100$\mathrm{DR}, 100-\mathrm{H}, 100-\mathrm{F}$ and the 300 Areas. The following sections provide general overviews of each area based on the initial site surveys and status changes in each area due to the Pollution Prevention Team's SWCSCEs and this update to the SWPPP. Specific status changes include elimination of NPDES process outfalls previously included in the SWPPP because they are nonstormwater discharges (Appendix E). Currently, two industrial process NPDES Permits exist for industrial type discharges from the Hanford Site. NPDES Permit No. WA-000374-3 was issued in 1981 and remains in effect. This permit authorizes discharges from eight outfalls located in the 100 and 300 Areas. NPDES Permit WA-002591-7 authorizes discharges from the 300 Area Treated Effluent Disposal Facility and was issued in October 1994. Additional detailed data for each area is provided in Appendices A and B. For each area, individual discharge locations have letters assigned to them and each potential point source conveyance has a specific number assigned to it. These letter/number distinctions are referenced in Appendices A and B.

\subsubsection{General Field Survey Findings}

Initial field surveys of Hanford Site facility areas were conducted during February-March, 1993, with several trips made to each area. The surveys covered the shorelines, embankments, and terraces at each area to determine if a potential to convey stormwater runoff existed. These surveys were designed to determine general discharge locations to the river, potential point source conveyances, drainage basins, and pollutant sources associated with those basins at each of the areas identified in the previous section.

In general, the ground cover in each area can be characterized according to four categories. These are gravel, riprap, river rock, and natural vegetation. In virtually all cases, the gravel appeared to have been brought in and levelled over an area. In several cases, it was apparent that riprap had been brought in and placed in channels leading to the river. Generally, 
river rock covered the upper portion of the river embankment and natural vegetation covered the lower portion. The natural vegetation consisted of desert grasses, sagebrush, and small bushes. As noted, small trees were present at some outfall locations.

General topographic characteristics along the riverbank were consistent between the areas. The ground near the river's edge was typically flat (estimated 0 to $5 \%$ grade). The lower portion of the embankment was usually gently sloped (estimated 5 to $20 \%$ grade) to moderately sloped ( 20 to $35 \%$ grade). The upper portion of the embankment was usually moderately sloped to steeply sloped ( $>35 \%$ grade). A terrace above the embankment was usually sloped gently toward the river.

As discussed in Section 1.1 a storm water Pollution Prevention Team (PPT) was organized as required by the Permit to study the identified outfalls and determine their appropriate disposition under storm water rules. The PPT performed the SWCSCEs which included researching the potential outfalls, identifying those that could actually be outfalls and inspecting them in the field annually. This information is incorporated into the following site specific sections.

\subsubsection{0-B and 100-C Area Field Survey Findings}

Five potential point source conveyances to the river were noted during the initial walkdown assessment. These conveyances include three runoff areas, a flume, and a pipe.

The PPT annual SWCSCEs indicate the pipe listed above was previously used for discharge of unused process wastewater, and does not receive stormwater. This point source conveyance will be eliminated from future SWCSCEs. None of the conveyances in the 100-B and 100-C Areas are permitted under NPDES Permit No. WA-000374-3. The location of the point source conveyances are identified in the outfall location maps in Appendix A with additional details and status provided in the description tables in Appendix B.

\subsubsection{0-D and 100-DR Area Field Survey Findings}

Three potential point source conveyances were noted during the initial walkdown assessment. These conveyances include two flumes and a runoff area near Building 181-D, which were further described in Appendix A of the baseline SWPPP (WHC 1993). None of the conveyances in the 100-D and 100-DR Areas are permitted under NPDES Permit No. WA000374-3.

These discharge locations will continue to be monitored on an annual basis by the PPT. The location of the point source conveyances are identified in the outfall location maps in Appendix A with additional details and status provided in the description tables in Appendix $\mathbf{B}$.

\subsubsection{0-F Area Field Survey Findings}

Fifteen potential point source conveyances were identified during the initial site surveys. These conveyances included five pipes and two flumes. The remaining conveyances were identified based on the presence of four areas with drums, a burial mound, trench, storage area with drums, miscellaneous concrete blocks, and piping materials. These conveyances are described in more detail in Appendix A of the baseline SWPPP (WHC 1993). None of the conveyances in the 100-F Area are permitted under NPDE: Permit No. WA-000374-3. 
Four of the fifteen point source conveyances that were identified during the initial field survey have been eliminated from the SWPPP. All four were determined by the PPT to not conduct stormwater to the Columbia River. Appendix E contains the justifications for their elimination from the SWPPP. The location of the point source conveyances are identified in the outfall location maps in Appendix A with additional details and status provided in the description tables in Appendix B.

\subsubsection{0-H Area Field Survey Findings}

Thirteen potential point source conveyances were identified during the initial field surveys. These conveyances included nine pipes and two areas of runoff over riprap. The remaining conveyances were an erosion area around a concrete headwall, and the slope below some miscellaneous wood and rusty metal rubble on the riverbank. These conveyances are described in more detail in Appendix A of the baseline SWPPP (WHC 1993). None of the conveyances in the 100-H Area are permitted under NPDES Permit No. WA-000374-3.

Three of the thirteen point source conveyances that were identified during the initial field survey have been eliminated from the SWPPP. Two are river stage recorders and do not conduct storm water runoff and one is a pipe leading from a monitoring well. The location of the point source conveyances are identified in the outfall location maps in Appendix A with additional details and status provided in the description tables in Appendix B.

\subsubsection{0-K Area Field Survey Findings}

Walkdowns covered areas west of the 100-K Area and access roads adjacent to the $107-\mathrm{K}$ retention basins and $181-\mathrm{K}$ pump houses. Additional walkdowns reassessed potential outfalls near the $107-\mathrm{K}$ and $181-\mathrm{K}$ structures.

Terrain in the $100-\mathrm{K}$ areas consisted of several identifiable areas:

- Floodplains were identified from west of the $181-\mathrm{KW}$ pumphouse to east of the 181-KE pumphouse. This area consisted of sand, gravel, and cobbles. The area generally consisted of terraces parallel to the river which ran the length of the 100-K Area except where they were broken by the two $181-\mathrm{K}$ access roads. The terraces were each approximately 50 $\mathrm{m}$ (164 ft) wide (perpendicular to the river) and were separated by steep transitions of approximately $3 \mathrm{~m}(10 \mathrm{ft})$. The overall width of this area ranged from $120 \mathrm{~m}$ ( $394 \mathrm{ft})$ west of $181-\mathrm{KW}$ to $200 \mathrm{~m}(656 \mathrm{ft})$ east of 181-KE.

- Access roads separated the floodplains into three sections. The roads included a major east-to-west road that separated the floodplain area from the 107-K water retention basin runoff areas, and two access roads that ran north-south to the end of the 181-K pumphouses. The access roads were all raised above adjacent natural elevations and consist of asphalt or compacted sand and gravel.

- Process areas were present in the 100-K Area including 107-K retention basins, adjacent runoff retention areas near the basins, and the remaining area between the 107-K structures. These areas generally consist of sand, gravel and cobbles and were slightly sloped towards the river, except for the runoff retention areas surrounding the $107-\mathrm{K}$ basins. These areas 
would drain to the floodplains by culverts passing under the adjacent access roads.

Except for the access roads, the floodplain immediately west of $100-\mathrm{KW}$, the shoreline within about $5 \mathrm{~m}(15 \mathrm{ft})$ of the river, and areas west of $107-\mathrm{KW}$, all areas discussed here were under radiological control and posted as surface contamination areas. Housekeeping throughout the 100-K Area appeared adequate. The 100-K reactors are retired; however, the fuel storage basins within the reactor buildings continue to operate for fuel storage purposes.

Fourteen potential point source conveyances were identified during the initial 100-K Area field surveys. All pipes and culverts (capped and uncapped), and any major erosion points that drained directly to the river or to any portion of the riverbank, were considered as potential outfalls. These conveyances, their current operational status and possible pollution sources are described in Appendix A of the baseline SWPPP (WHC 1993). Six of the 14 conveyances drained to floodplains at $90 \mathrm{~m}(300 \mathrm{ft})$ or greater distance from the river. One conveyance drained to the shoreline approximately $12 \mathrm{~m}(40 \mathrm{ft})$ from the river. Three conveyances drained through pipes directly to the river. The remaining four conveyances were pipes that were located on the 181-K pumphouse access roads. One conveyance (labeled outfall 003 ) is permitted under NPDES Permit No. WA-000374-3.

Of the initial fourteen potential point source conveyances identified, six were determined by the stormwater PPT to either not convey stormwater discharges or permitted under a separate NPDES permit and they have been eliminated from the SWPPP. The location of the point source conveyances are identified in the outfall location maps in Appendix A with additional details and status provided in the description tables in Appendix B.

\subsubsection{0-N Area Field Survey Findings}

Initial field survey areas included the main 100-N complex (excluding reactor exclusion areas), roads east of the complex towards the river, and the shoreline east of building 181-N. Depending upon the slope of the terrain and characteristics of the ground cover, the assessment included structures, facilities, and materials adjacent to the river.

The ground cover in the $100-\mathrm{N}$ Area can be characterized according to five categories. These are concrete/asphalt, gravel, riprap, river rock and natural vegetation. In virtually all cases, the gravel appeared to have been brought in and levelled over an area. In several cases, it was apparent that riprap had been brought in and placed in channels leading to the river. Generally, river rock covered the upper portion of the river embankment and natural vegetation covered the lower portion. The natural vegetation consisted of desert grasses, sagebrush, and small bushes. Small trees were present at some outfall locations.

The $100-\mathrm{N}$ site is graded with multiple terraces. The gentle slopes of each terrace are flat (estimated 0 to $5 \%$ grade) and are separated by steeper slopes (estimated 30 to $45 \%$ grade) at the transitions between terraces. This terrace system achieves good containment of potential runoff for most of the 100-N Area. The transition portions of the terrain, however, allow for rapid runoff and potential transport of potential contamination sources. All of the potential contamination sources identified in the walkdown were located on or adjacent to a transition slope.

Twenty-seven potential point source conveyances were identified during the initial $100-\mathrm{N}$ field surveys. All pipes and culverts (capped and uncapped), and all major $\epsilon$ :osion points which drained directly to the river or to any portion of the riverbank were considared as potential 
WHC-SD-EN-EV-021, Rev. 1

conveyances. Additionally, the ditch north of 181-N (identified in WHC-S-0437 as the "Diesel Oil Interceptor Trench") was included as a conveyance since there is a potential for concentration from undefined runoff sources above the trench with subsequent leaching to the river. One of these conveyances (labeled outfall 007) is permitted under NPDES Permit No. WA-000374-3.

Historical and current engineering and topographic drawings of the $100-\mathrm{N}$ complex were reviewed in an attempt to identify all pipes found in the survey. Twenty of the twenty-seven conveyances were identified. All twenty-seven conveyances and their status, including potential pollutant sources, were described in Appendix A of the baseline SWPPP (WHC 1993).

The stormwater PPT made significant progress at N-Area. By plant walk-downs, data searches and data confirmation all twenty-seven potential point source conveyances identified in the baseline SWPPP (WHC 1993) were determined not to be discharging to the river. Some point source from pipes were identified as non-operational and groundwater run-off was identified as not capable of reaching the river. Supporting documentation can be found in the Storm Water Pollution Prevention Plan for N Reactor Plant (Appendix D, Enclosure 3).

Although none of the point sources were determined to be discharging to the Columbia River, they had the potential to discharge in the future. Best Management Practices (BMPs) were applied where indicated in the baseline SWPPP (WHC 1993). In seven of the initial twenty-seven potential point source conveyances in the baseline SWPPP, BMPs were not identified. For these seven it was suggested that the source end conveyance should be identified to assess potential stormwater contamination and determination of applicable BMPs and monitoring requirements. All seven of these potential point source conveyances were determined to be pipes that were nonoperational.

Eight of the original twenty-seven potential point source conveyances have been eliminated from the SWPPP. Justifications for their removal are included in Appendix E. The location of the point source conveyances are identified in the outfall location maps in Appendix A with additional details and status provided in the description tables in Appendix B.

\subsubsection{Area Field Survey Findings}

Ten potential point source conveyances were noted during the walkdown assessment. These conveyances included three areas of runoff, three pipes, two culverts, a half-pipe, and an area of erosion, which are described in more detail in Appendix A of the baseline SWPPP (WHC 1993). Two of the conveyances (outfalls 001 and 013) in the 300 Area are permitted under NPDES Permit Numbers WA-002591-7 and WA-000374-3, respectively.

Two of the ten potential point source conveyances initially identified have been eliminated from the SWPPP. One outfall was intended to be is permitted by an NPDES permit, which has since been canceled and the outfall is scheduled for removal in FY96. The other was determined by the PPT to not be a stormwater discharge location. Appendix E contains the justifications for their elimination from the SWPPP. The status for the remaining eight potential point source conveyances are shown in the outfall location maps in Appendix $A$ and are described in more detail in the outfall description tables in Appendix B 
WHC-SD-EN-EV-021, Rev. 1

\subsection{STORMWATER POLLUTION PREVENTION PLAN DESCRIPTION}

\subsection{SWPPP OBJECTIVES}

As stated previously, the Hanford Site SWPPP focuses on two major objectives to ensure compliance of each facility area within the Hanford Site with the terms and conditions of the NPDES General Permit.

- Identifying the sources of pollutants with the potential to affect the quality of point source discharges of stormwater runoff associated with industrial areas within the Hanford Site to the Columbia River, and

- Identifying BMPs that will be implemented to minimize and control pollutants in potential point source discharges of stormwater runoff associated with industrial areas within the Hanford Site.

Implementation of the Hanford Site SWPPP has and will continue to ensure that stormwater runoff discharged from a facility area to the surface environment does not contain contaminants that would be detrimental to the Columbia River. The Hanford Site SWPPP is comprised of area-specific data packages (Appendices A, B and C) for each industrial area that has the potential to introduce pollution to the river via stormwater runoff. The elements of the SWPPP are discussed in more detail in the following sections.

\subsection{STORMWATER POLLUTION PREVENTION TEAM}

The baseline SWPPP was reviewed and evaluated by a sitewide stormwater Pollution Prevention Team (PPT) prior to the October 1, 1993 deadline for implementation of the SWPPP. This PPT includes representatives of all affected operations contractors on site. As required by General Permit No. WA-R-00-000F (WA-R-00-A17F) Section IV, Part D, Section 4.c, an annual report must be developed by DOE-RL and retained on site to verify that the requirements listed in General Permit No. WA-R-00-000F (WA-R-00-A17F) are being implemented. The PPT has produced two annual reports to satisfy this requirement which contains the results of inspections of the stormwater outfalls listed in the baseline SWPPP (WHC 1993). These reports are titled Hanford Site Storm Water Comprehensive Site Compliance Evaluation Report (WHC 1994, 1995). The PPT has met regularly since May 1994 to conduct the SWCSCE as discussed previously in Section 1.1. PPT members in each area surveyed the storm water outfalls to determine the discharge status and provided an updated status of each outfall. The inspections (SWCSCEs) consisted of a visual inspection of each outfall and the surrounding area that drains to the outfalls for any sign of changes and/or erosion. Additional responsibilities of the PPT include maintaining, and revising the SWPPP, as necessary and identifying BMPs to control potential sources of pollution. The PPT is also responsible for identifying appropriate staff and providing training in areas of spill control, BMP implementation, record keeping, and inspection procedures. The PPT members are listed by name, facility area title/position, telephone number, and their particular responsibilities in each annual Hanford Site Storm Water Comprehensive Site Compliance Evaluation Report (WHC 1994, 1995). The list of team members is displayed or posted within each facility area so that other area personnel are aware who is responsible for stormwater management within the facility area.

The PPT is also responsible for insuring that spill prevention and response procedurer are incorportate into each affect facility's spill control plan. Such procedures have already been 
developed and presented in the various spill control plans developed for each of the areas on the Hanford Site. These plans can be modified, if necessary, to address stormwater pollution prevention.

Training guidelines are currently being developed that will facilitate the PPT's management of the SWPPP. Additional PPT responsibilities are discussed further in Sections 3.10 and 3.11 .

\subsection{SITE MAPS}

Appendix A contains maps showing the following:

- Outline of drainage areas for each point-source conveyance documenting the flow direction and their general discharge locations to the Columbia River;

- Locations of potential pollution sources associated with the areas, including, but not limited to: maintenance areas, industrial waste management areas (landfills, waste piles, treatment facilities, disposal areas); outside storage areas for raw materials and by-products, surface contamination areas, and any other industrial areas of concern that could come into contact with stormwater runoff.

\subsection{INVENTORY OF SIGNIFICANT MATERIALS EXPOSED TO STORMWATER}

NPDES industrial stormwater discharge permit regulations (CFR 1991 and FR 1992) require the SWPPP to contain an inventory of the "significant materials" that are handled, stored, or processed on-site, and that have been exposed to stormwater runoff in the past three years from the effective issuance data of the NPDES General Permit. Under 40 CFR 122.26(b)(12), "significant materials" are defined as follows: raw materials; fuels; solvents, detergents, and plastic pellets; finished materials such as metallic products; raw materials used in food processing or production; hazardous substances designated under Section 101(14) of CERCLA; any chemical the facility is required to report pursuant to EPCRA Section 313; fertilizers, pesticides; and waste products such as ashes, slag, and sludge that have the potential to be released with stormwater discharges. Due to the extensive number of industrial facilities on the Hanford Site, inventories of "significant materials" for each facility were not prepared specifically for this SWPPP. Instead a complete site-wide inventory of "significant materials" is found in the 1991 Tier Two Emergency and Hazardous Chemical Inventory (DOE-RL 1992). This document was prepared under Section 312 of EPCRA, also known as Title III of the Superfund Amendments and Reauthorization Act (SARA), which requires operators of certain facilities that manufacture (including import), process, or otherwise use toxic chemicals listed under 40 CFR 372 to provide an inventory of these chemicals over certain specified volume thresholds. Reporting requirements include the chemical name, volumes on site, days on site, storage and location codes, and emergency contacts. In addition to this document, chemical inventories are also provided in the various spill control plans referenced throughout this document.

No "significant materials" were identified during the field surveys that might impact the Columbia River during stormwater runoff. 
Under NPDES General Permit requirements, the following additional SWPPP and monitoring requirements must be implemented for industrial facilities where EPCRA Section 313 "water priority chemicals" are stored, handled, processed, or transferred:

- Appropriate containment, drainage control, and/or diversionary structures must be provided. In addition, in liquid storage areas where stormwater runoff comes into contact with any equipment, tank, container, or other vessel used for Section 313 water priority chemicals, appropriate measures must be taken to minimize discharges of these chemicals.

- Stormwater discharges that come into contact with any equipment, tank, container, or other vessel or area used for storage of a Section 313 water priority chemical, or located at a truck or rail car loading or unloading area where a Section 313 water priority chemical is handled must be monitored semi-annually and reported annually for: oil and grease, biochemical oxygen demand (BOD-5 day), chemical oxygen demand (COD), total suspended solids (TSS), total Kjeldahl nitrogen (TKN), total phosphorus, $\mathrm{pH}$, whole effluent acute toxicity testing, and any other Section 313 water priority chemical for which the facility reports.

On June 7, 1994 five facilities identified by WHC as storing EPCRA Section 313 water priority chemicals were visited by a Registered Professional Engineer from Golder Associates Inc. as part of the process of certifying the SWPPP. The facilities included $183 \mathrm{KE}, 183 \mathrm{~N}$, $283 \mathrm{KE}, 283 \mathrm{~W}$ and 315 where chlorine gas is used as an anti-microbial agent in water treatment facilities for Hanford Site water supplies.

Chlorine gas is delivered to the specified locations as a gas in pressurized steel containers specifically designed for safe storage of chlorine. These containers are generally housed in covered enclosures surrounded by locked fencing. Covered storage of the chlorine containers is the stormwater BMP for chlorine storage.

The failure mode for the chlorine containers would be a leak or break in the piping. In this case, the gas would either be contained within a building or immediately disperse into the atmosphere. Chlorine gas is a hazardous chemical and a chlorine gas release would be a serious safety concern. However, a chlorine gas release would not pose a threat to stormwater.

Chlorine injection occurs within buildings, and is the stormwater BMP for chlorine usage. Floor drains in these areas connect to process or sanitary sewers, and not to stormwater sewers. Thus, a leak of chlorinated water at these points would not have significant potential for direct contact with stormwater or the potential for discharge to stormwater. Chlorine could have an impact to stormwater only under a combination of unlikely events, i.e., chlorine overdosing of the treated water followed by leakage or rupture of the water supply tanks, pumps, or piping. Even in this case, there is negligible potential for significant impact on the receiving water (the Columbia River).

Areas of chlorine usage are subject to routine monitoring and maintenance as part of the Hanford safety program, as well as routine operational monitoring and inspection. In addition, a significant leak of chlorine gas would be immediately obvious. The safety concern is sufficient to ensure prompt maintenance of any dangerous leak. Considering the level of attention to safety at the Hanford Site, and the negligible threat to stormwater from chlorine storage and use, no additional or separate inspection and recordkeeping is necessary. However, these areas shall be 
inspected yearly as part of the update of this SWPPP for any conditions which could reasonably lead to failure or discharge. This inspection shall include, at a minimum:

valves and piping handling chlorine gas
valves, piping, and pumps handling chlorinated water
chlorine storage containers
chlorine storage enclosures
chlorine injection areas
other equipment or conditions which could affect the ability of chlorine to contact
or discharge to stormwater.

\subsection{PAST SPILLS AND LEAKS}

Appendix C contains lists of "significant" spills and leaks of toxic or hazardous substances that have occurred at each facility area, and are based on site records of spills meeting CERCLA and Ecology reporting requirements. These lists include the date, location, description, response (if known) to each spill, as well as measures to be taken to prevent future similar spills. "Significant spills" includes releases in excess of reportable quantities, defined as follows: "A reportable quantity (RQ) discharge occurs when a quantity of a hazardous substance or oil is spilled or released within a 24-hour period of time and exceeds the RQ level assigned to that substance under CERCLA or the CWA. These levels or quantities are defined in terms of gallons or pounds. Regulations listing these quantities are contained in 40 CFR 302.4, 40 CFR 117.21, and 40 CFR 110.10"(CFR 1991).

In addition to the data sources described above, spill records are also maintained by ICF Kaiser Hanford Company (ICF KH) and Battelle Pacific Northwest Laboratories (PNL). PNL maintains spill records in the Environmental Compliance Section, and provides a monthly letter report of spills to DOE-RL. ICF KH maintains (including subcontractors) spill records in their Environmental Programs and Integration Department.

\subsection{NON-STORMWATER DISCHARGES}

The SWPPP requires certification, signed by an authorized individual of the permittee, that the facility area(s) has or have been evaluated or tested for non-stormwater discharges, which would include identification of potential non-stormwater discharge locations, dates, and descriptions of the methods used and results of any test and/or evaluation for such discharges. If certification is not feasible, the source identification section of the SWPPP. shall indicate why the certification was not feasible, along with the identifications of potential significant sources of nonstormwater at the facility. In adrition, any facility within the Hanford Site that is unable to provide non-stormwater certification must notify the EPA Director by October 1,1993 , or 180 days after the date of submitting an NOI application, for any facility which began to discharge stormwater runoff associated with industrial activity after October 1, 1992. Examples of nonstormwater discharges include any process water, air conditioner condensate, non-contact cooling water, vehicle wash water, or sanitary wastewater.

EPA was notified in a letter dated September 24, 1993 (Holt 1993) that the nonstormwater discharge certification would not be completed by October 1, 1993 as required by the general permit. DOE-RL estimated at this time that the outfall certification process should be completed by June 1,1994. DOE-RL has since determined that because the outfall serves a research facility operated by Pacific Northwest Laboratory and because research facilities are not 
WHC-SD-EN-EV-021, Rev. 1

within the scope of federal stormwater rules, the outfall serving the facility would not require certification for non-stormwater discharges. Therefore, unless EPA disagrees with this interpretation, DOE-RL will not be submitting to EPA the general permit certification required (Wisness 1994). Documentation providing the rationale and justification for this interpretation can be found in Wisness (1994).

\subsection{STORMWATER MONITORING DATA}

NPDES industrial stormwater regulations (CFR 1991 and FR 1992) require that a SWPPP must contain a summary of any existing stormwater sampling data, and that it describe the sample collection procedures used. There is currently no stormwater monitoring data for any of the facilities in the Hanford Site areas, as would be expected in a region with an average of only 6 inches of annual precipitation. Therefore, no stormwater monitoring data has been presented in the SWPPP.

\subsection{SUMMARY OF POTENTIAL POLLUTANT SOURCES AND RISKS}

Based on the field surveys discussed in Section 2.1.2, Appendix B contains a summary of each facility's industrial activities with a high risk potential to contaminate stormwater runoff, including those areas and activities associated with materials loading and unloading, outdoor storage, outdoor manufacturing or processing, on-site waste disposal, and significant dust or particulate-generating activities. Any pollutants of concern that may be associated with such activities are also described.

\subsection{BEST MANAGEMENT PRACTICES}

Typically, two broad categories of BMPs are used by industry to control point source, non-routine discharge of pollutants from sources such as stormwater runoff, drainage from raw material storage and waste disposal areas, and areas where spills or leaks have occurred. These categories include non-structural source control BMPs, and structural control/runoff treatment BMPs.

Non-structural source control BMPs are typically used as a first line, low-cost defense against the release of pollutants into stormwater runoff. These types of BMPs include various methods such as good housekeeping, employee training, preventive maintenance (visual inspections and equipment maintenance), spill prevention and response procedures (spill control plans), record keeping and reporting, using mulches and covers on disturbed soils, putting roofs over outside storage areas, and sediment and erosion control measures. In general, source control BMPs are more cost-effective to use than runoff treatment BMPs since it is usually more cost-effective to prevent water quality impacts rather than treat or remove pollutants after the fact.

Structural control/runoff treatment BMPs include facilities that remove pollutants by gravity settling of particulate pollutants (detention facilities - including basins, wet ponds, constructed wetlands), oil/water separators, infiltration (sumps, basins, trenches) and filtration devices (sand filtration), biological uptake (biofiltration swales and vegetative filter strips), and streamside stabilization (vegetative or structural, bioengineering, etc.). These types of BMPs can accomplish pollutant load reductions if properly designed and maintained. However, pollutant loads from urban areas are typically increased such that, even with the use of BMPs, it is unlikely they will be reduced to levels approximating pre-development conditions. Nevertheless, three factors govern the pollutant removal capability of a runoff treatment BMP: the removal 
mechanisms used, the fraction of the annual runoff volume that is effectively treated, and the nature of the pollutant being removed.

Table 3-1 summarizes the existing BMPs that apply to materials exposed to the elements, as identified in the spill control plans prepared for each of the Hanford Site Areas.

BMPs have been completed, or are in progress, for the stormwater outfalls that were determined during inspection to have a potential to discharge pollution to the Columbia River as a result of stormwater runoff. Outfalls that were determined not to be potential sources of pollution to the Columbia River will continue to be inspected annually for changes in permit status. Those outfalls that were identified as being NPDES permitted for industrial process discharge will be removed from future SWCSCE reports and SWPPP updates but will be monitored for changes in permit status (WHC 1994).

The outfalls associated with research facilities (e.g. the research facility operated by Pacific Northwest Laboratory [PNL]) are not required to comply with the federal stormwater regulations. A letter was sent to EPA on June 23, 1994 (Wisness 1994) notifying them of the change in status for these outfalls. However, in keeping with the spirit of the stormwater regulations, PNL will continue to inspect these outfalls on an annual basis to determine compliance with permit requirements. These outfalls are located in the 100-F Area (outfall $\mathrm{J}$ ) and in the 300 Area (outfalls A through D)(WHC 1994).

\subsection{SWPPP IMPLEMENTATION}

As mentioned in Section 1.1, the baseline SWPPP developed for the Hanford Site industrial facilities was implemented before October 1, 1993. In implementing the SWPPP, the following items were accomplished:

- $\quad$ The pollution prevention team was identified and assigned responsibility for implementing the various components of the SWPPP, including BMPs and

- Three training sessions were conducted for the PPT after approval of the baseline SWPPP (WHC 1993) and before October 1, 1993. Additional training of the PPT has occurred prior to the inspections of the outfalls every year.

- Training has been incorporated into the WHC CM-7-5 Manual (WHC 1991) which is used to track all environmental permits and training for the site. Where appropriate, contractor personnel on-site will also be trained in relevant aspects of the SWPPP. Employees and contractor personnel working in facility areas where EPCRA 313 water priority chemicals are used or stored must also be trained, at least once a year, in applicable requitements and regulations, and features and operations of facilities that are designed to minimize discharges of 


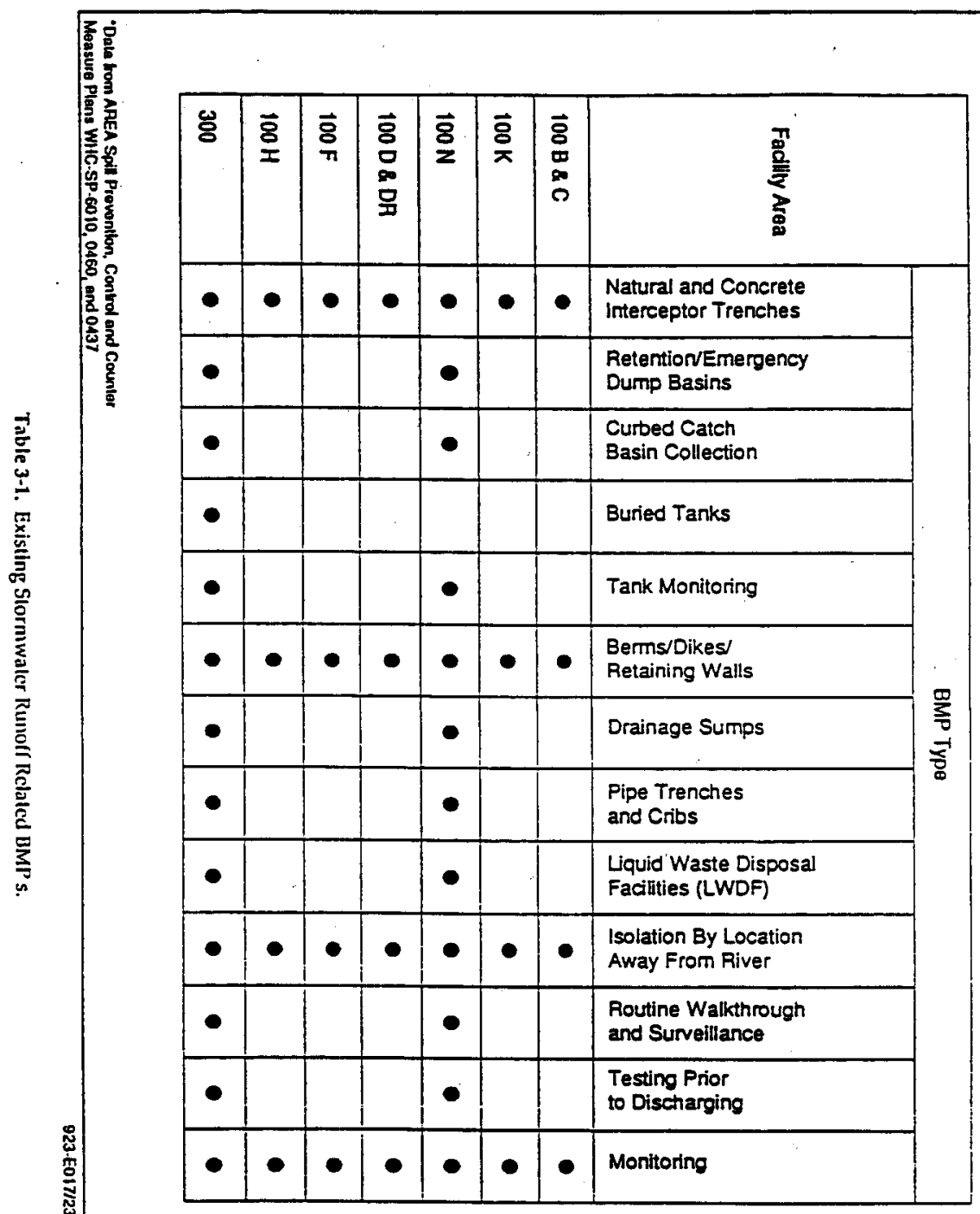


Section 313 water priority chemicals, particularly spill prevention procedures and BMPs. This training is covered as part of the operator certification process for water treatment facilities.

- $\quad$ Regular reporting intervals have been established in the first annual Hanford Site Storm Water Comprehensive Site Compliance Evaluation Report (WHC 1994). Annual reports will cover the period from July to June the following year and the report is to be certified by October 1 of each year.

When pollution prevention activities are conducted at facilities, these activities should be reported to the facility and/or area environmental compliance officer or his/her appointee.

\subsection{COMPREHENSIVE SITE COMPLIANCE EVALUATIONS}

The Hanford Site SWPPP has been implemented since October 1, 1993 and comprehensive site compliance evaluations have been conducted by the PPT on an annual basis (WHC 1994, 1995). These evaluations included:

- Inspection of stormwater drainage areas for evidence of pollutants entering the drainage system

- Evaluation of the effectiveness of BMPs

- Observation of any structural control BMPs, sediment/erosion controls, and other stormwater BMPs to ensure proper operation

- $\quad$ Preparing a report summarizing inspection results and follow up actions, including signing the report and identifying the date of inspection and personnel who conducted the inspection

Additional activities required to maintain compliance include:

- $\quad$ Record keeping and internal reporting of spills, leaks, inspections, and maintenance activities. For spills and leaks, records should include information such as the date and time of the incident, weather conditions, cause, and resulting environmental problems.

- SWPPP revisions resulting from major changes in a facility's design, construction, operation, or maintenance. As mentioned earlier in Section 1.1, if the pollution prevention team subsequently discovers after April 1, 1993, that an industrial facility located within a Hanford Site facility area uses and/or stores federal EPCRA Section 313 water priority chemicals, then the SWPPP for such a facility must be reviewed, evaluated and certified by a Registered Professional Engineer in order to incorporate SWPPP modifications addressing special regulatory requirements for monitoring, reporting, training, and preventive maintenance practices at EPCRA 313 facilities. Recertification must take place every three years thereafter or as soon as practicable after significant modifications are made to the facility. By means of the certification the engineer, having examined the facility and being familiar with the SWPT $P$ must attest that 
WHC-SD-EN-EV-021, Rev. 1

the SWPPP has been prepared in accordance with good engineering practices. Such certification shall in no way relieve the owner or operator of a facility covered by the SWPPP of their duty to prepare and fully implement the SWPPP. 


\subsection{REFERENCES}

Berman, L., C. Hartline, N. Ryan, and J. Throne, May 1991, Water Quality: Urban Runoff Solutions, American Public Works Association Special Report No. 61.

Code of Federal Regulations (CFR), 1991, Parts 122 - 124.

Chien, Y.M., 1989, Chemical Spill Prevention Control and Counter Measures Plan - 100 Areas, WHC-SP-0460, Westinghouse Hanford Company, Richland, Washington.

DOE, 1987, Disposal of Hanford Defense High Level, Transuranic and Tank Wastes, Final Environmental Impact Statement, DOE/EIS-0113 (vol. 1 of 5), U.S. Department of Energy, Washington, D.C.

DOE, 1991, Overview of the Hanford Cleanup Five-Year Plan; U.S. Department of Energy, Richland, Washington.

DOE-RL, 1991, Environmental Restoration and Waste Management Site-Specific Plan for the Richland Operations Office - Hanford Site Five-Year Plan Fiscal Years 1993-1997, $D O E / R L-91-25$, U.S. Department of Energy, Richland, Washington.

DOE-RL, 1992, 199I Tier Two Emergency and Hazardous Chemical Inventory-Emergency Planning and Community Right-To-Know Act, Section 312, U.S. Department of Energy Richland Operations Office, Richland, Washington

Duffield, G.W., 1991, 300 Area Spill Retention Control and Counter Measures Plan, WHC-SP0610, Westinghouse Hanford Company, Richland, Washington.

Ecology et al., 1991, Hanford Federal Facility Agreement and Consent Order, Washington Department of Ecology, U.S. Environmental Protection Agency, and U.S. Department of Energy, Olympia, Washington.

Ecology and USDOE, 1991, Consent Order No. DE 9INM-177, Washington Department of Ecology, U.S. Department of Energy, Olympia, Washington.

EPA, 1992, "Storm Water Management for Industrial Activities, Developing Pollution Prevention Plans and Best Management Practices", EPA 832-R-92-006, U.S. Environmental Protection Agency, Office of Wastewater Enforcement and Compliance, Washington, D.C.

Federal Register (FR), November 16, 1990, Volume 55, No. 222, Page 47990.

Federal-Register (FR), September 9, 1992, Volume 57, No. 175, Pages 41236 and 41344.

Haggard, R.D., 1991, 1100 Area Chemical Spill Control Plan, WHC-SP-xxxx, Westinghouse Hanford Company, Richland, Washington.

Haggard, R.D., 1992a, 700 Area Chemical Spill Control Plan, WHC-SP-0780, Westinghouse Hanford Company, Richland, Washington. 
WHC-SD-EN-EV-021, Rev. 1

Haggard, R.D., 1992b, 300 Area Chemical Spill Control Plan, WHC-SP-0910, Westinghouse Hanford Company, Richland, Washington.

Holt, 1993, Notification to the USEPA Regarding Certification of Storm Water Discharges, Letter to C.E. Findley from Robert G. Holt DOE-RL, \#93-RPS-359, September 24, 1994.

McKarns, 1991, 400 Area Spill Prevention, Control, and Counter Measures Plan, WHC-SP-0634, Westinghouse Hanford Company, Richland, Washington.

PNL, 1989, Status of FY 1988 Soil-Water Balance Studies on the Hanford Site, PNL-6750/UC70, Battelle Pacific Northwest Laboratories, Richland, Washington.

PNL, 1990, Natural Groundwater Recharge and Water Balance at the Hanford Site, PNL7215/UC-802, Battelle Pacific Northwest Laboratories, Richland, Washington.

Rokkan, D.J., 1988, Westinghouse Hanford Company 100 Areas Environmental Releases for 1987, WHC-EP-0165, Westinghouse Hanford Company, Richland, Washington.

Rokkan, D.J., 1989, Westinghouse Hanford Company 100 Areas Environmental Releases for 1988, WHC-EP-0165-1, Westinghouse Hanford Company, Richland, Washington.

Rokkan, D.J., 1990, Westinghouse Hanford Company 100 Areas Environmental Releases for 1989, WHC-EP-0165-2, Westinghouse Hanford Company, Richland, Washington.

WHC, 1990, Westinghouse Hanford Company Effluent Report for 300, 400, and 1100 Area Operations for Calendar Year 1989, WHC-EP-0257-01, Westinghouse Hanford Company, Richland, Washington.

WHC, 1991, Environmental Compliance Manual, WHC-CM-7-5, Westinghouse Hanford Company, Richland, Washington.

WHC, 1993, Hanford Site Storm Water Pollution Prevention Plan, WHC-SD-EN-EV-021, Rev. 0 , Westinghouse Hanford Company, Richland, Washington.

WHC, 1994, Hanford Site Storm Water Comprehensive Site Compliance Evaluation Report, WHC-SD-EN-EE-014, Rev. 1, Westinghouse Hanford Company, Richland, Washington.

WHC, 1995, Hanford Site Storm Water Comprehensive Site Compliance Evaluation Report, WHC-SD-EE-015, Rev. 0, Westinghouse Hanford Company, Richland, Washington.

Wisness, 1994, Non-Storm Water Discharge Certification Under Storm Water General Permit WA-00-A17F, Letter to Joseph Wallace, USEPA from Steven H. Wisness, DOE-RL, \#94-RPS-245, June 23, 1994. 
WHC-SD-EN-EV-021, Rev. 1

APPENDIX A

STORMWATER OUTEALL MAPS

AF-1-i 


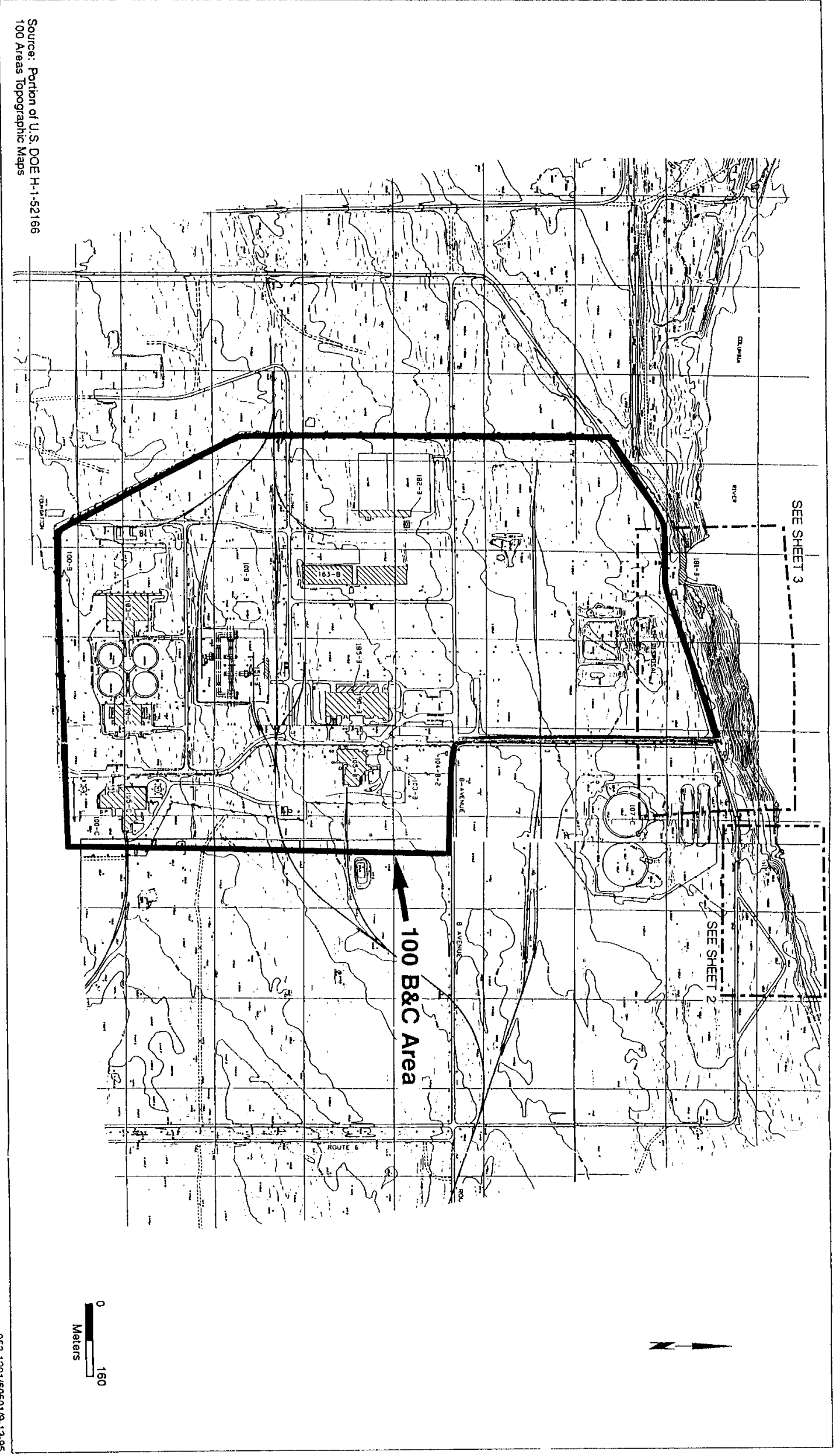




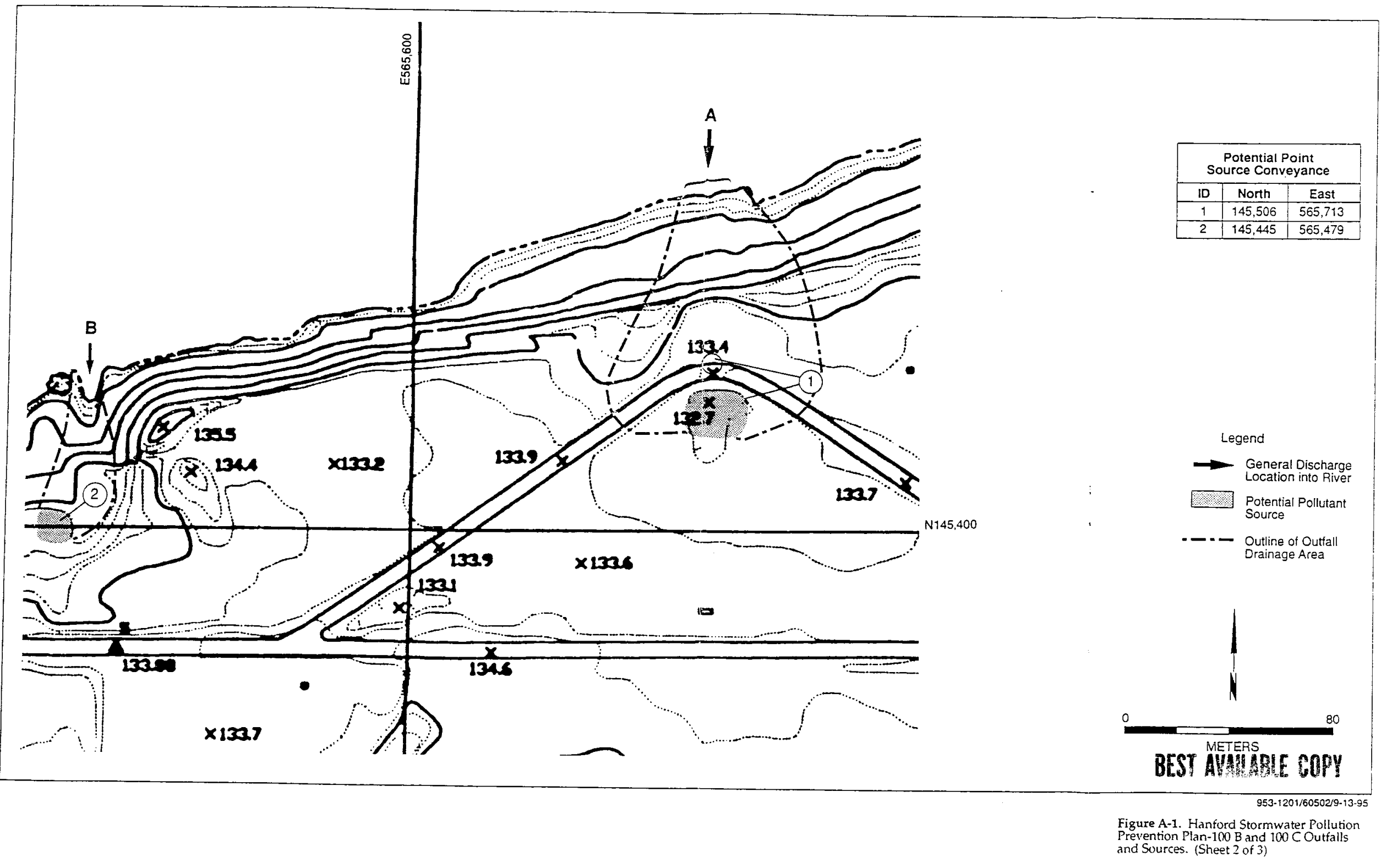




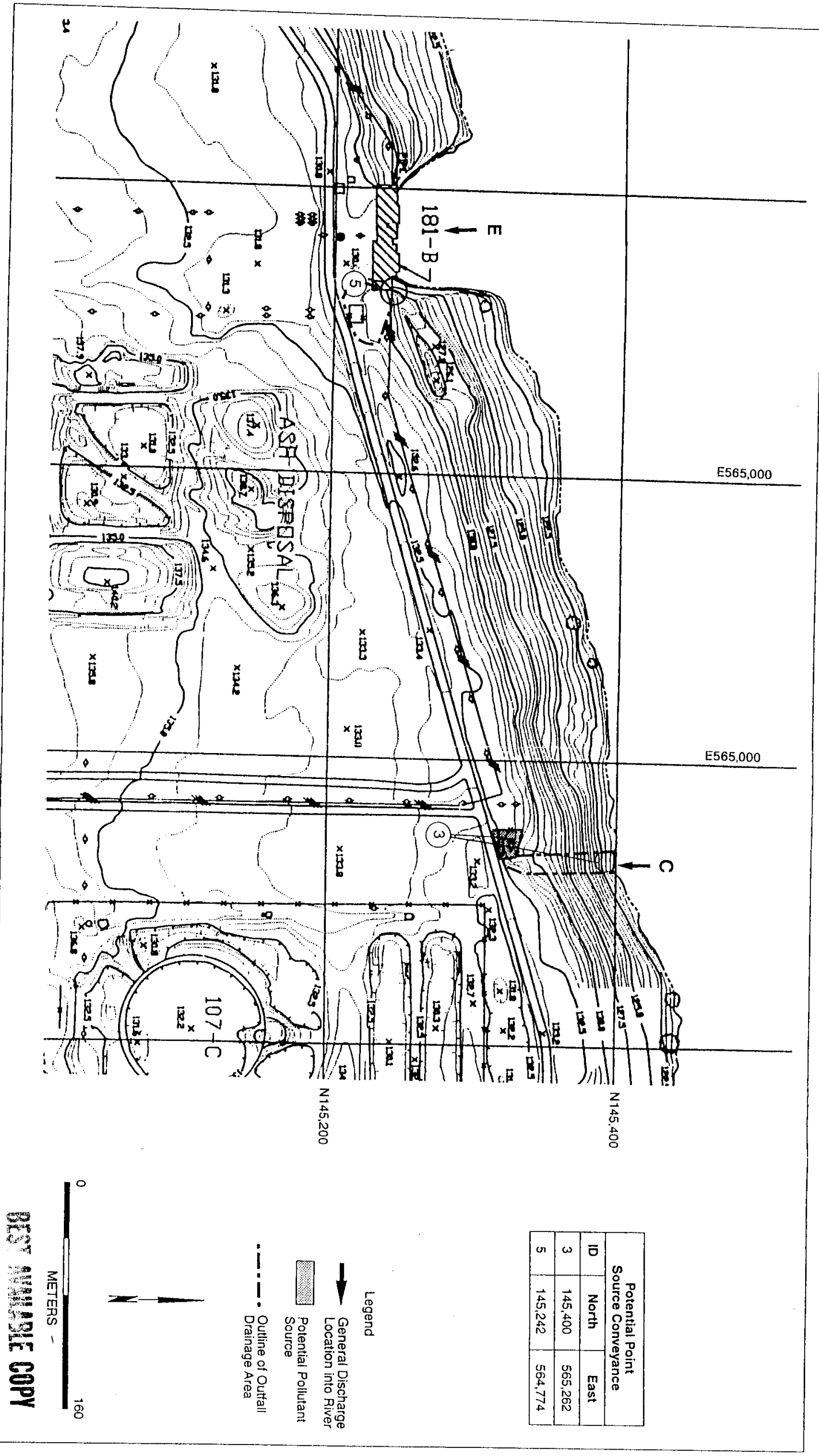

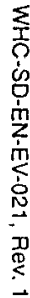




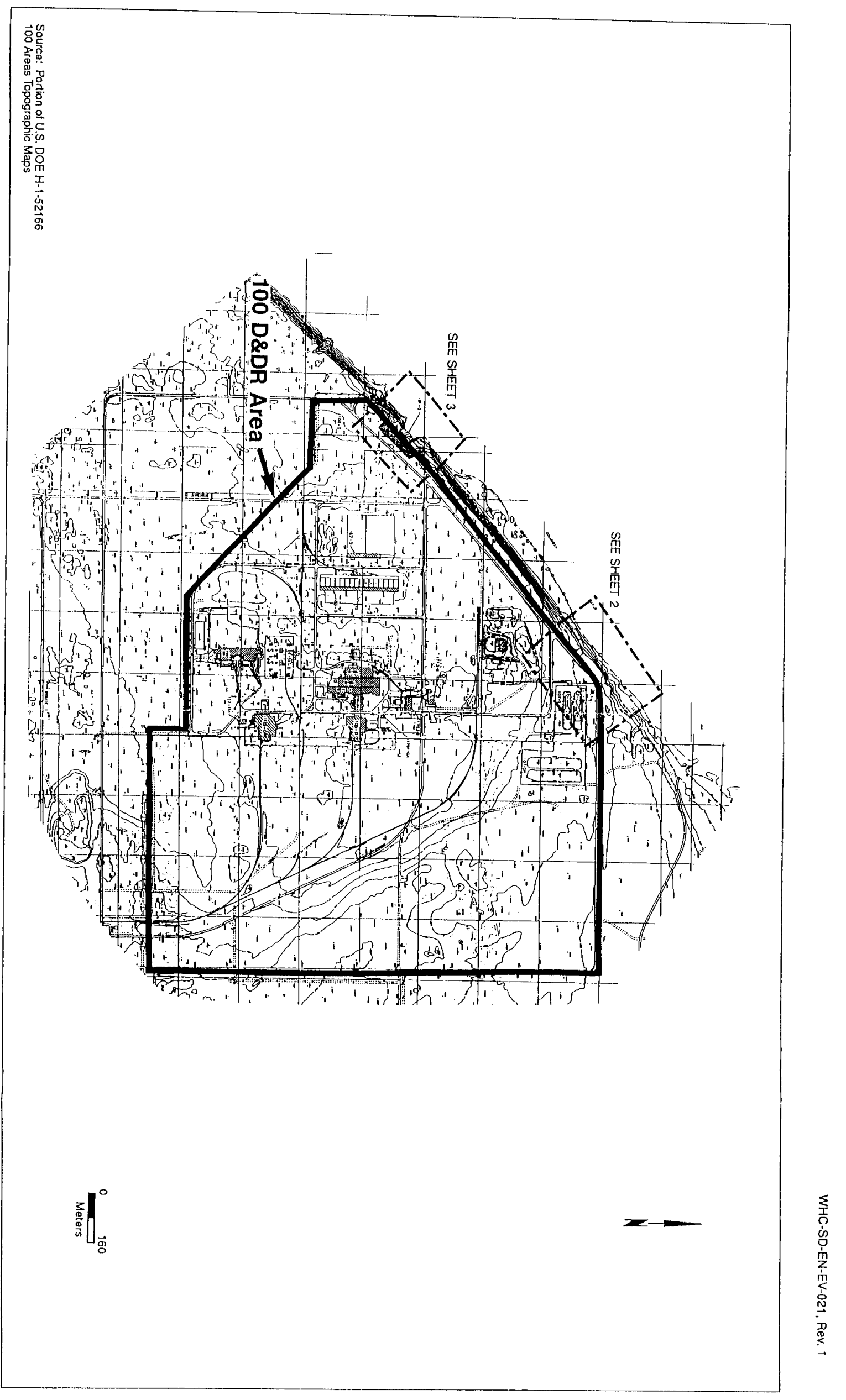



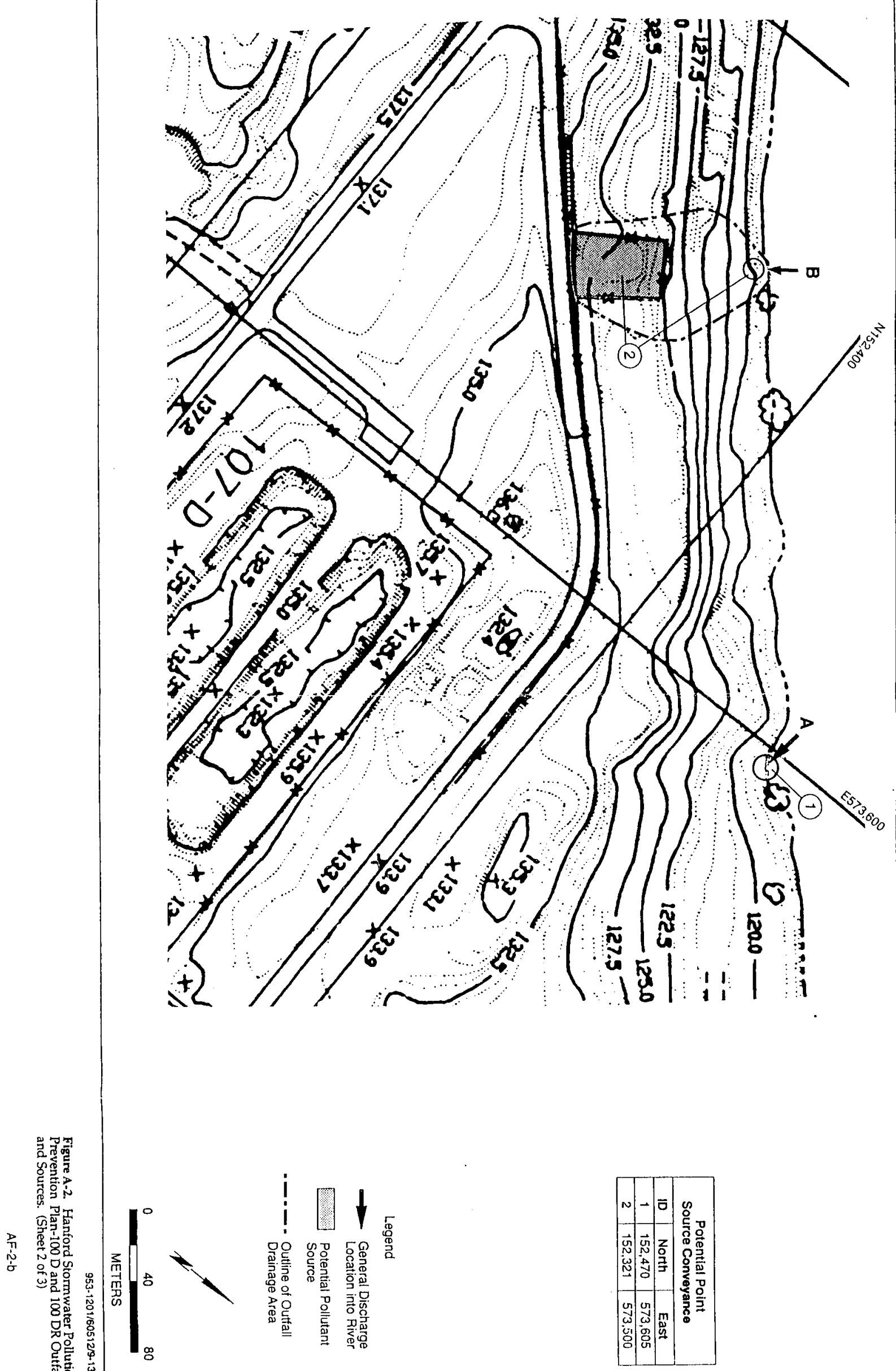

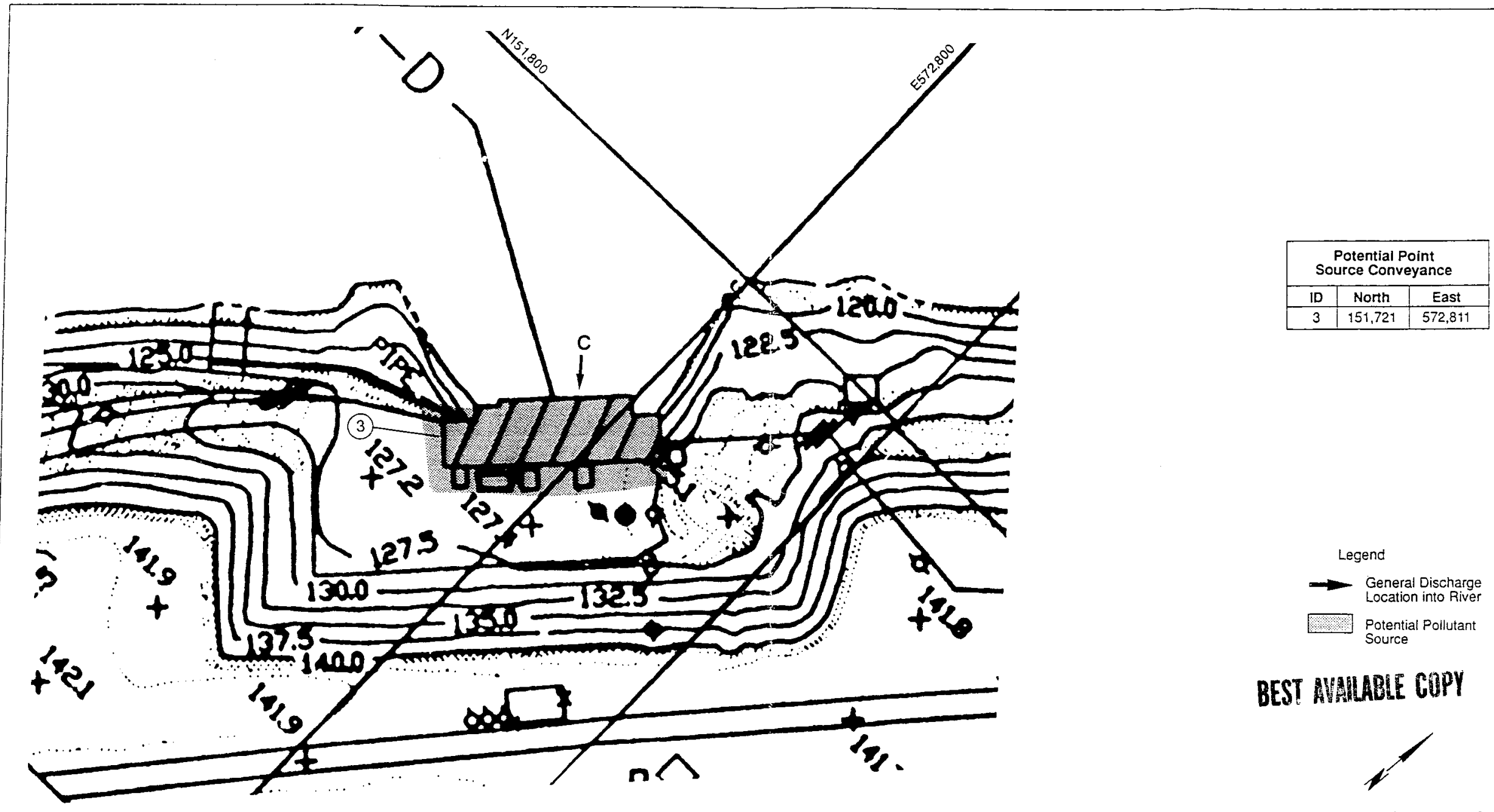

BEST WMLABLE COPY

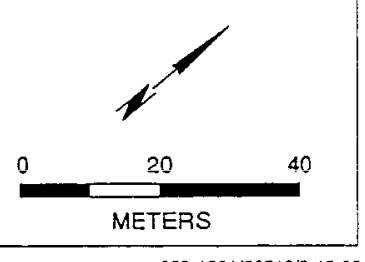

953-1201/605 139-13-95 Figure A-2. Hanford Stormwater Pollution
Prevention Plan-100 D and $100 \mathrm{DR}$ Outfalls
and Sources. (Sheet 3 of 3 ) 


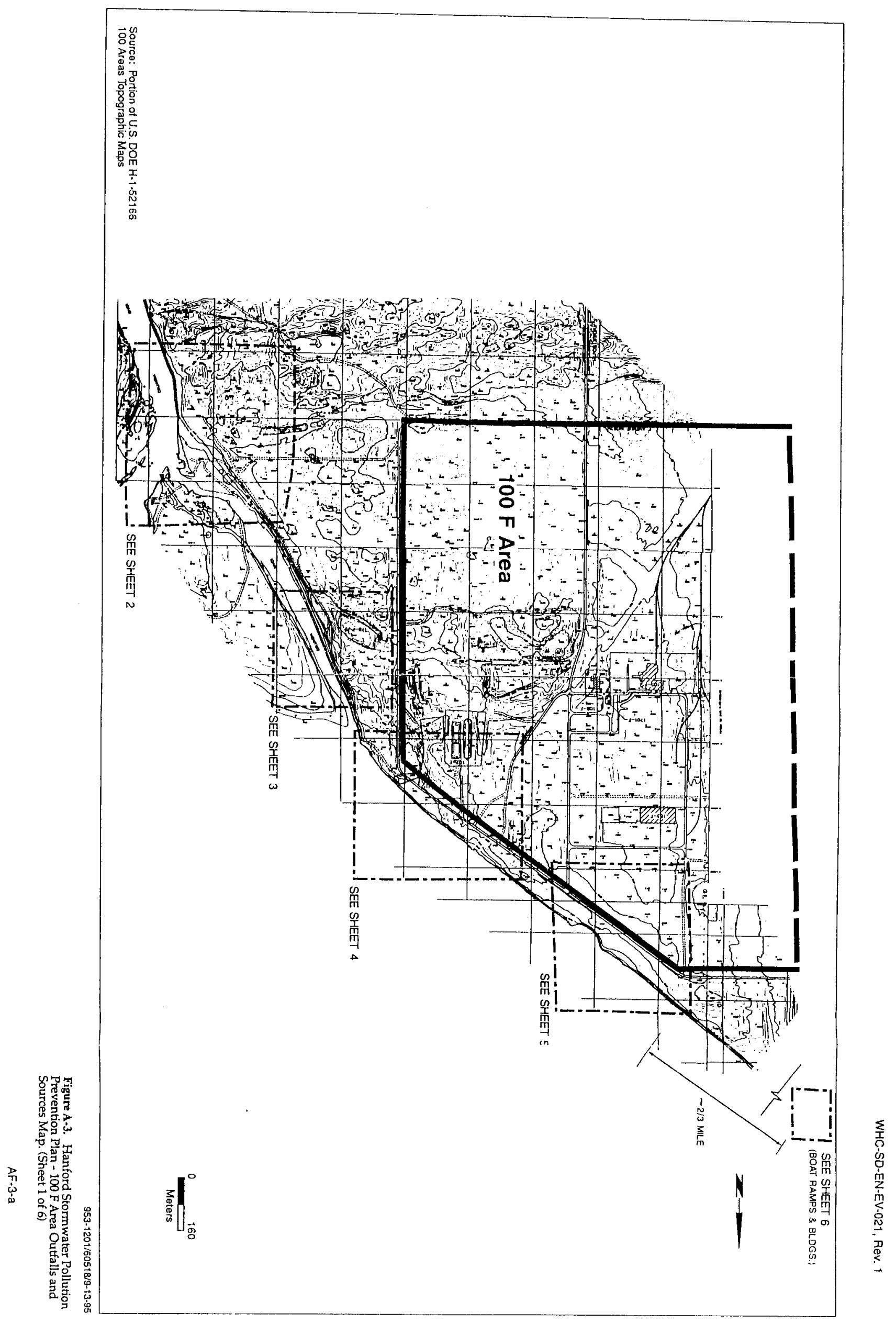




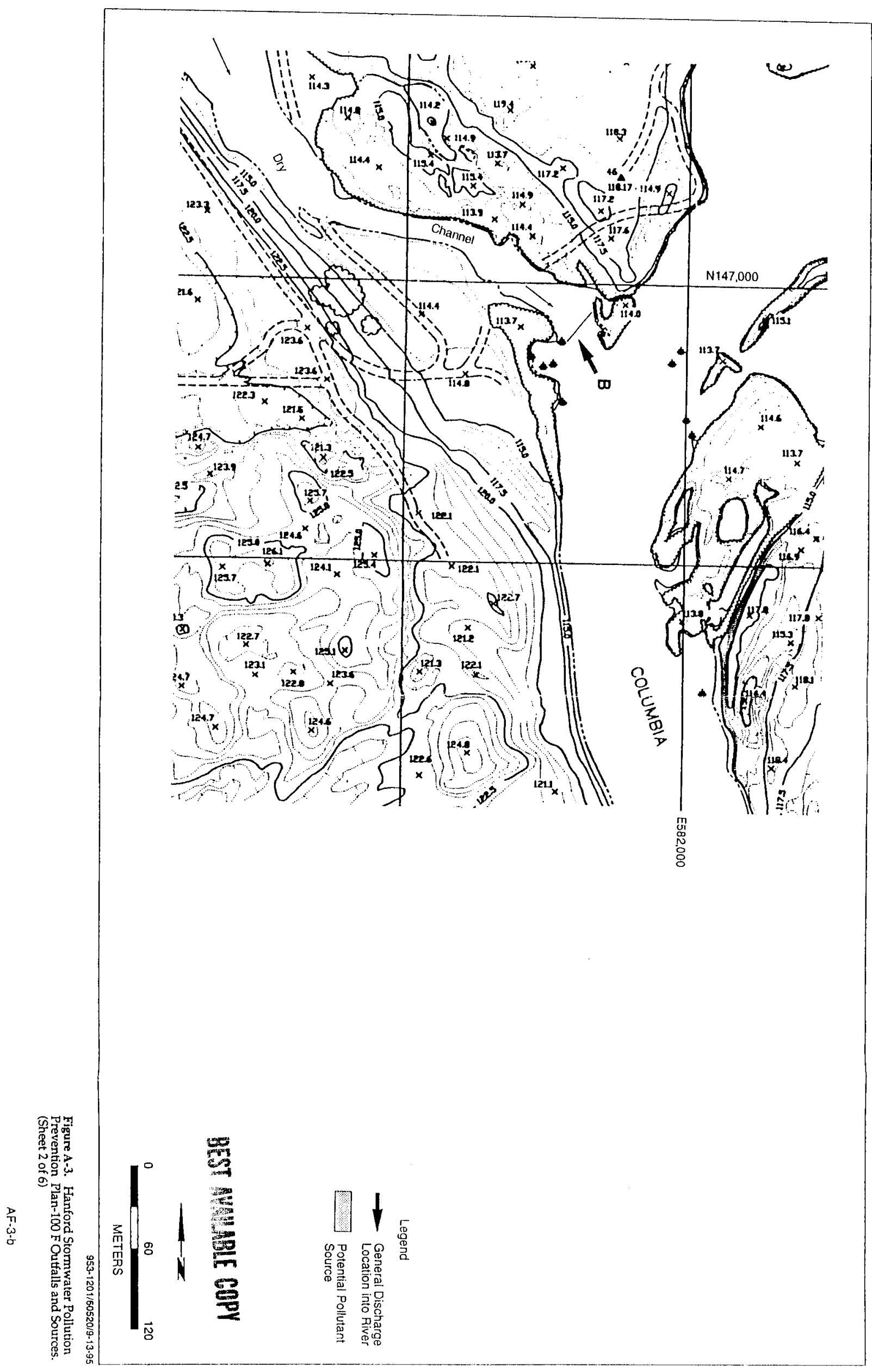




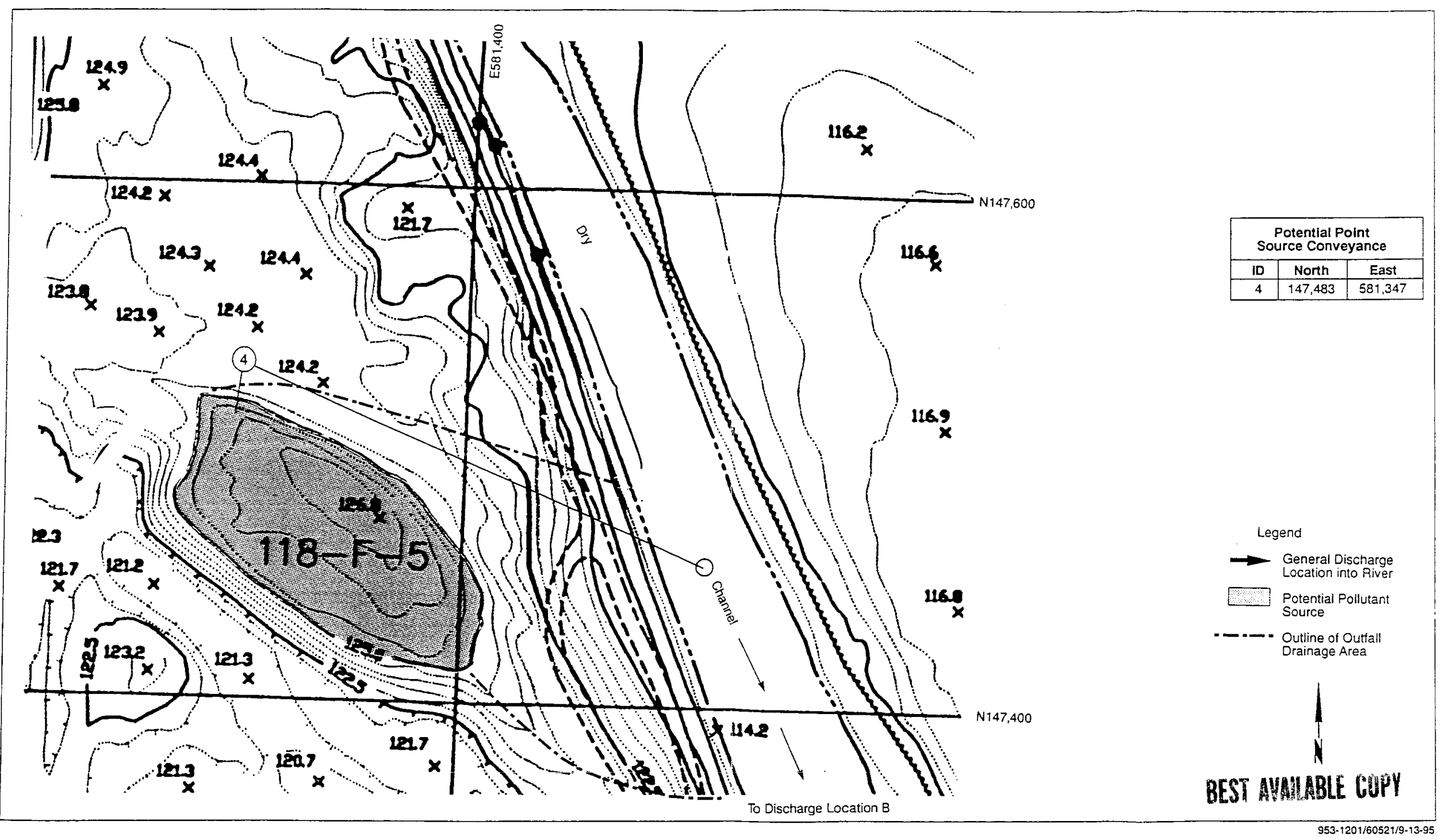

Figure A-3. Hanford Stormwater Tollution Prevention
(Sheet 3 of 6 ) 

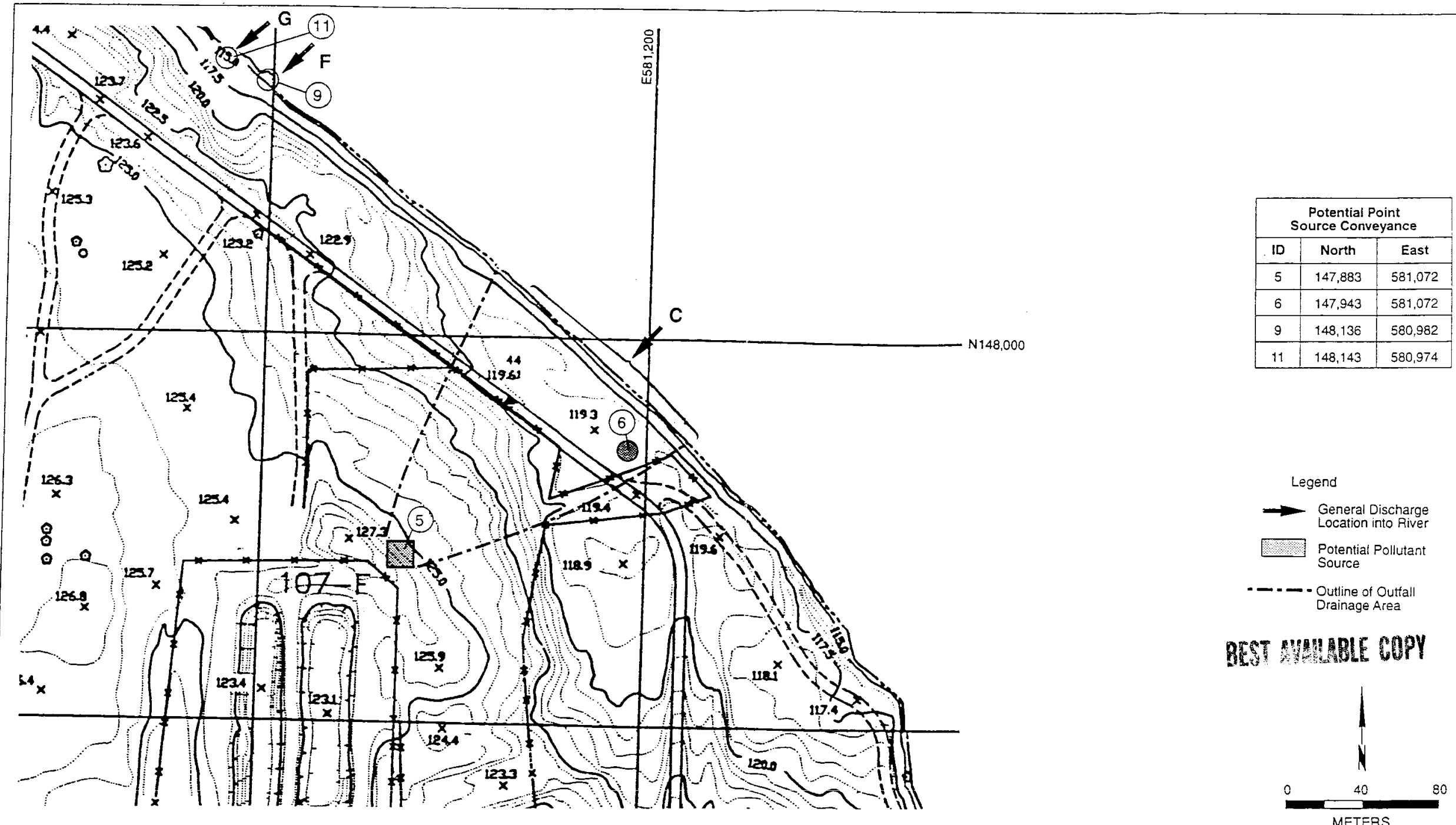

Legend

$\rightarrow$ General Discharge

Potential Pollutant - Outline of Outfall
Orainage Area

BET YHAMBE COPY

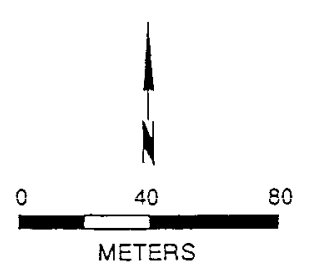
Figure A-3. Hanford Stormwater Pollution (Sheet 4 of 6 ) 


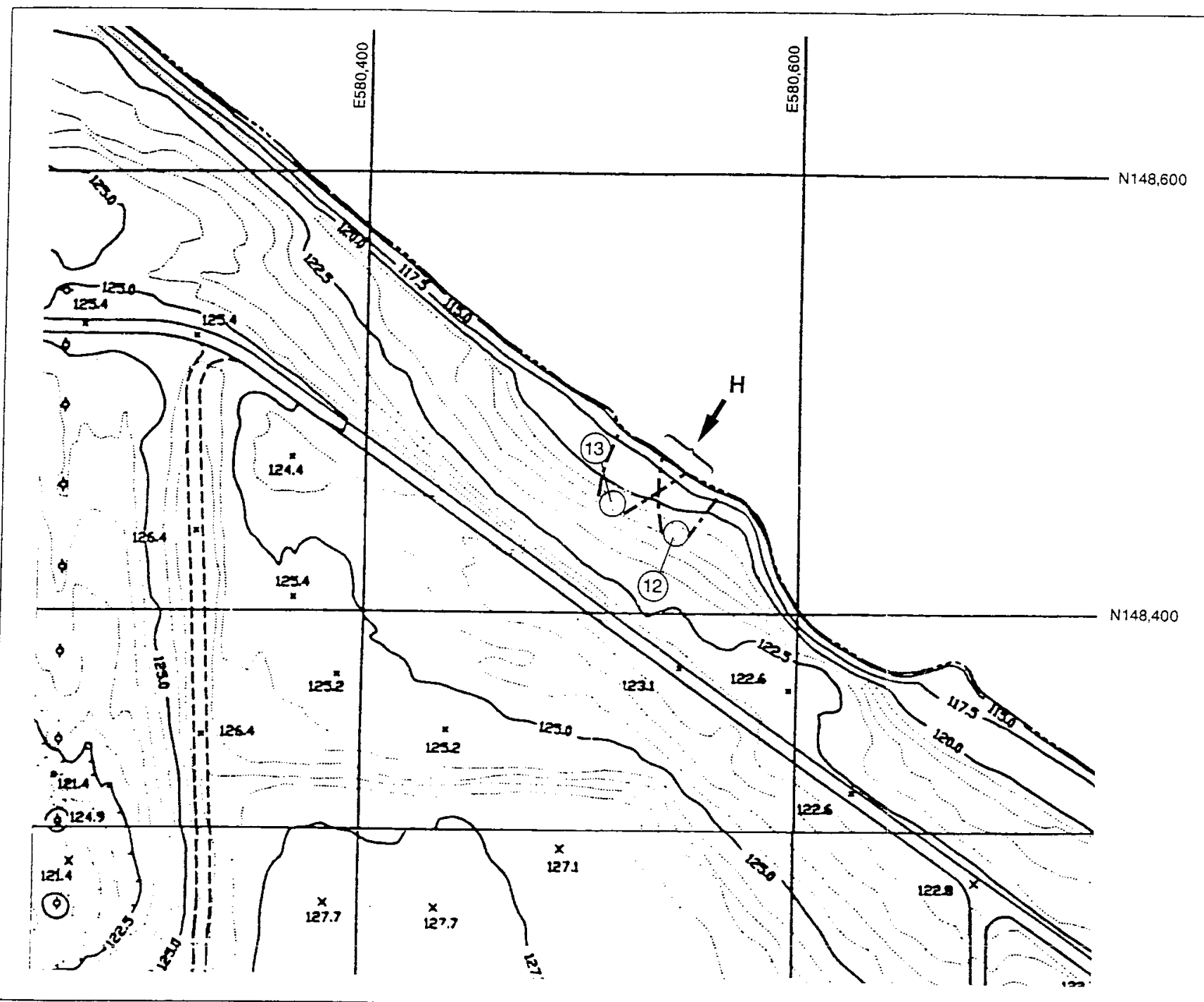

Potential Point Source Conveyance ID North East \begin{tabular}{|c|c|c|}
\hline 12 & 148,442 & 580,532 \\
\hline
\end{tabular} \begin{tabular}{|c|c|c|}
148,442 & 580,532 \\
\hline & 148,460 & 580,506 \\
\hline
\end{tabular}

Legend

$\rightarrow$ General Discharge Potential Polfutant Outline of Outfall
Drainage Area MON SUDBLE COPY

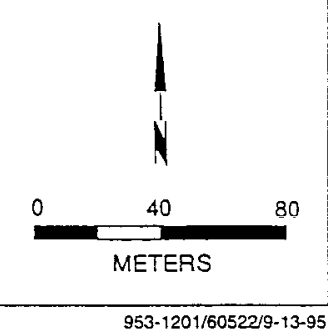




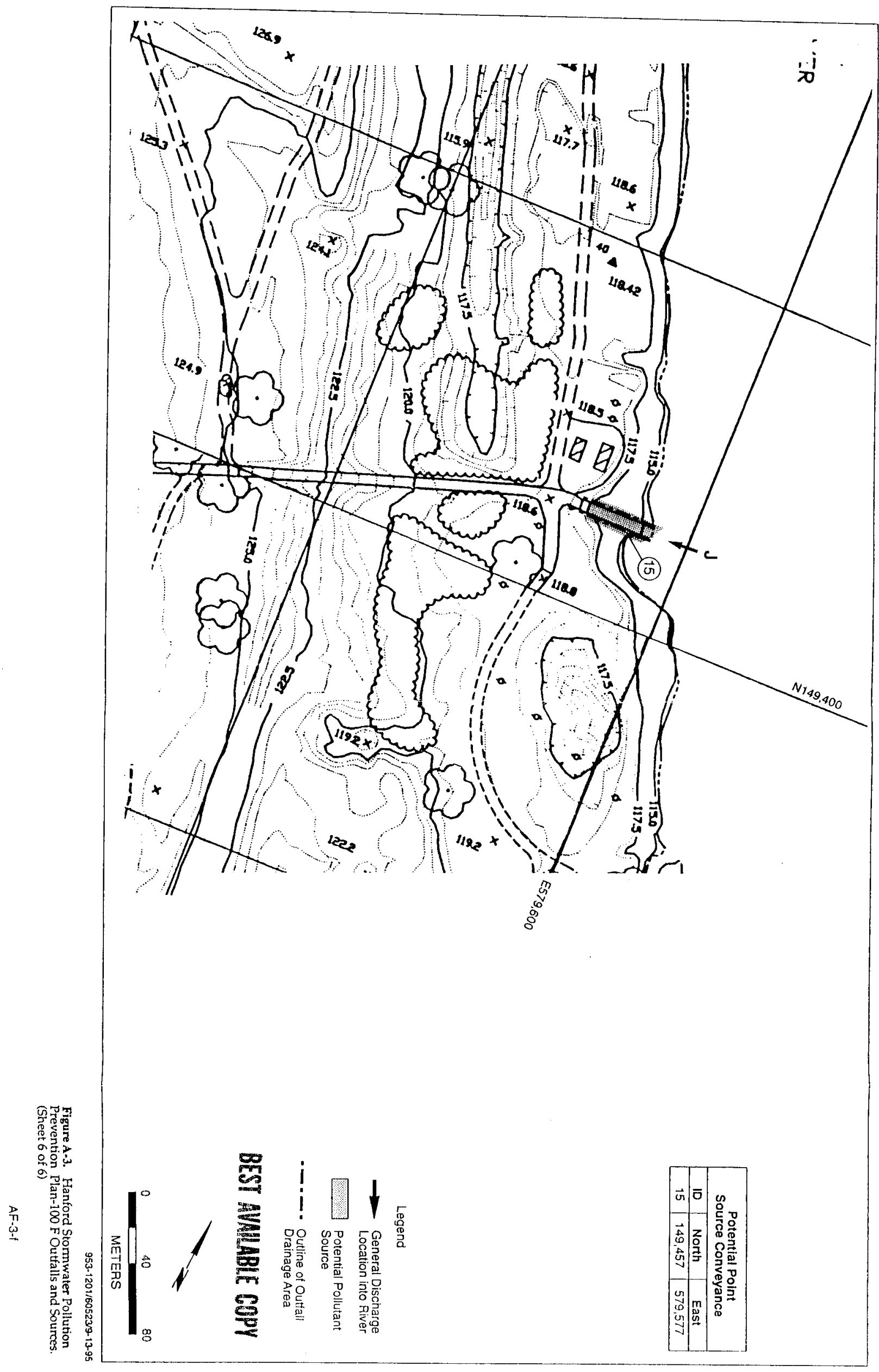

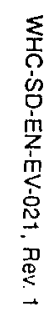




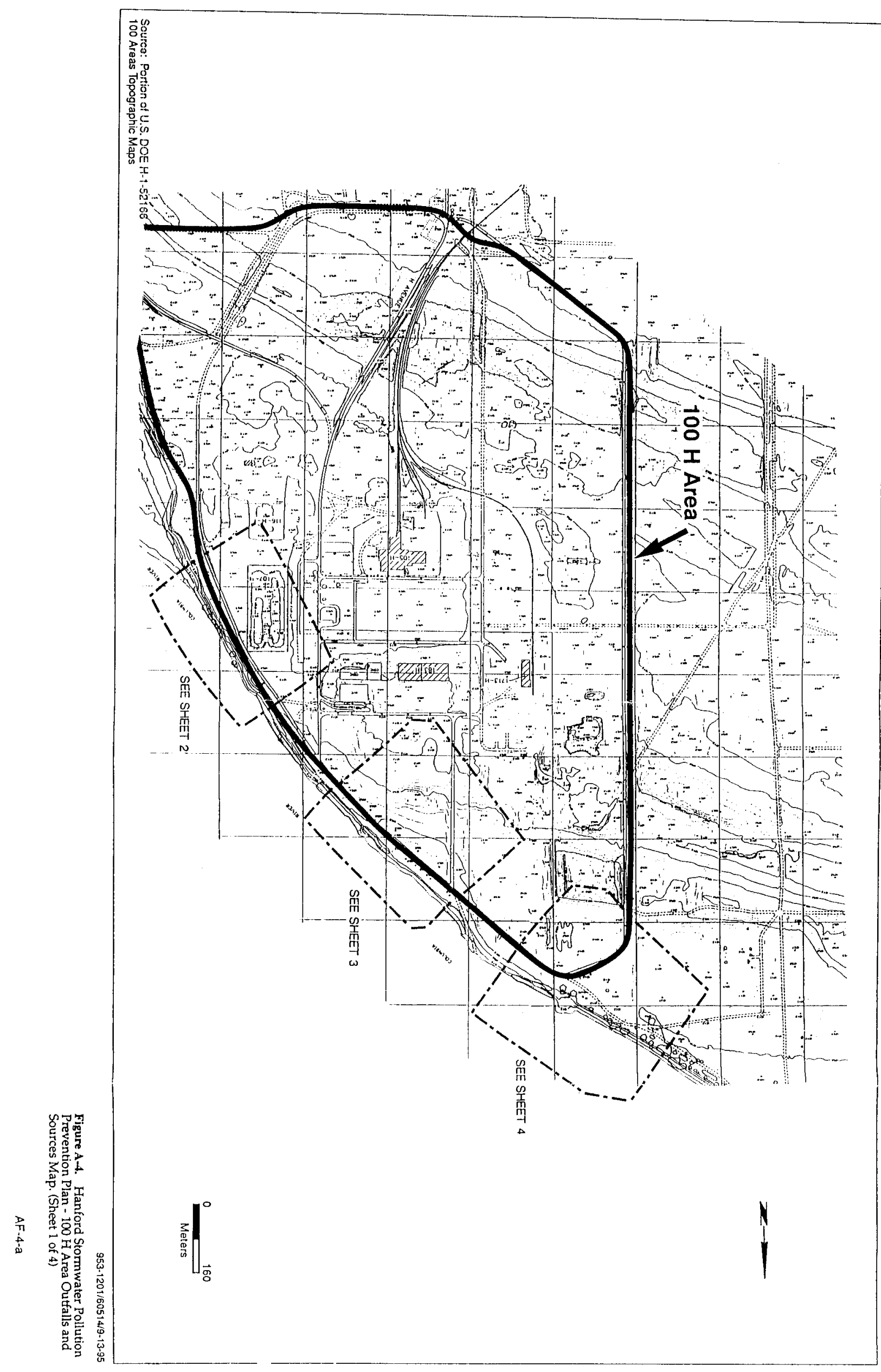




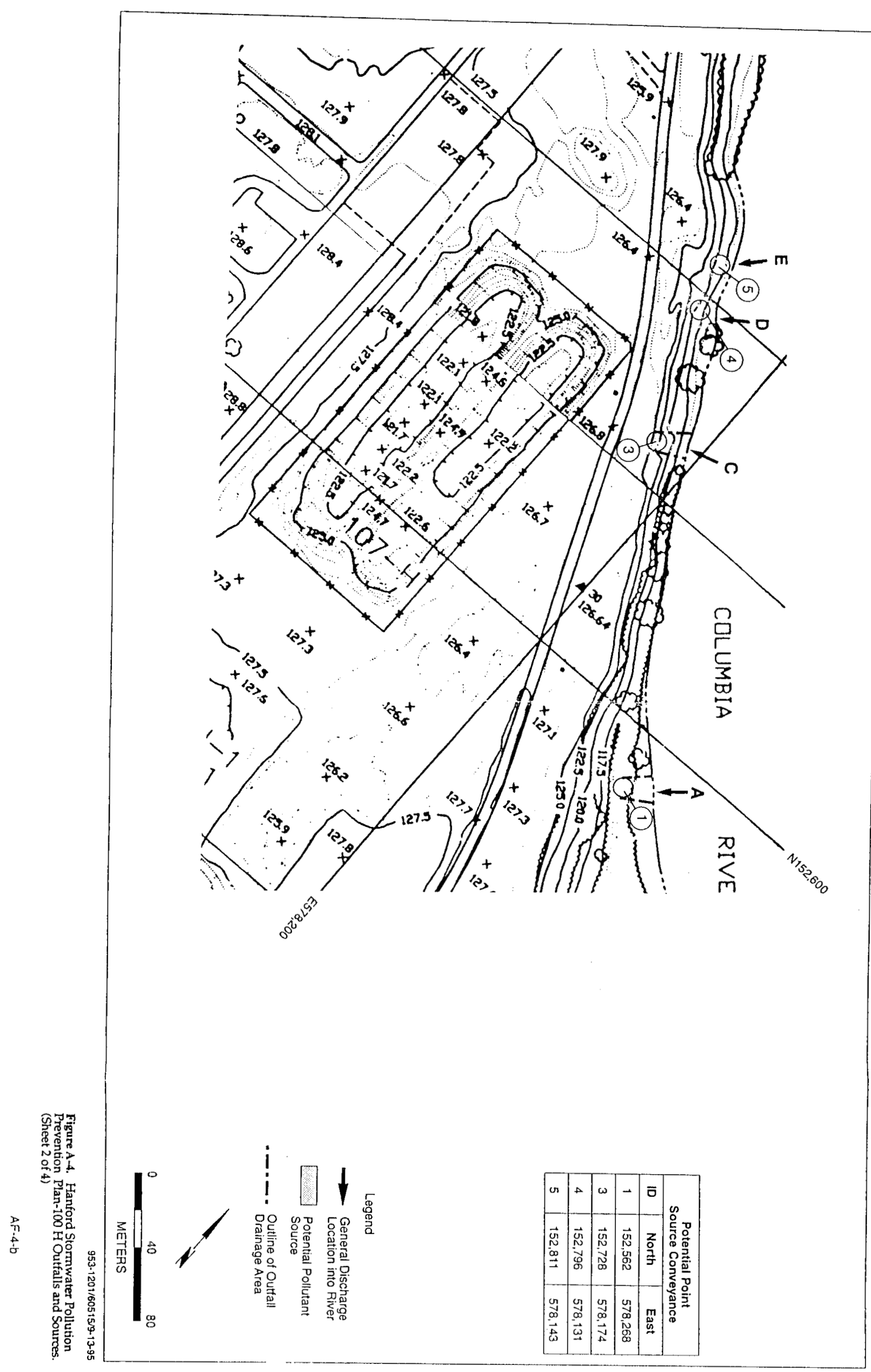

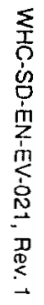




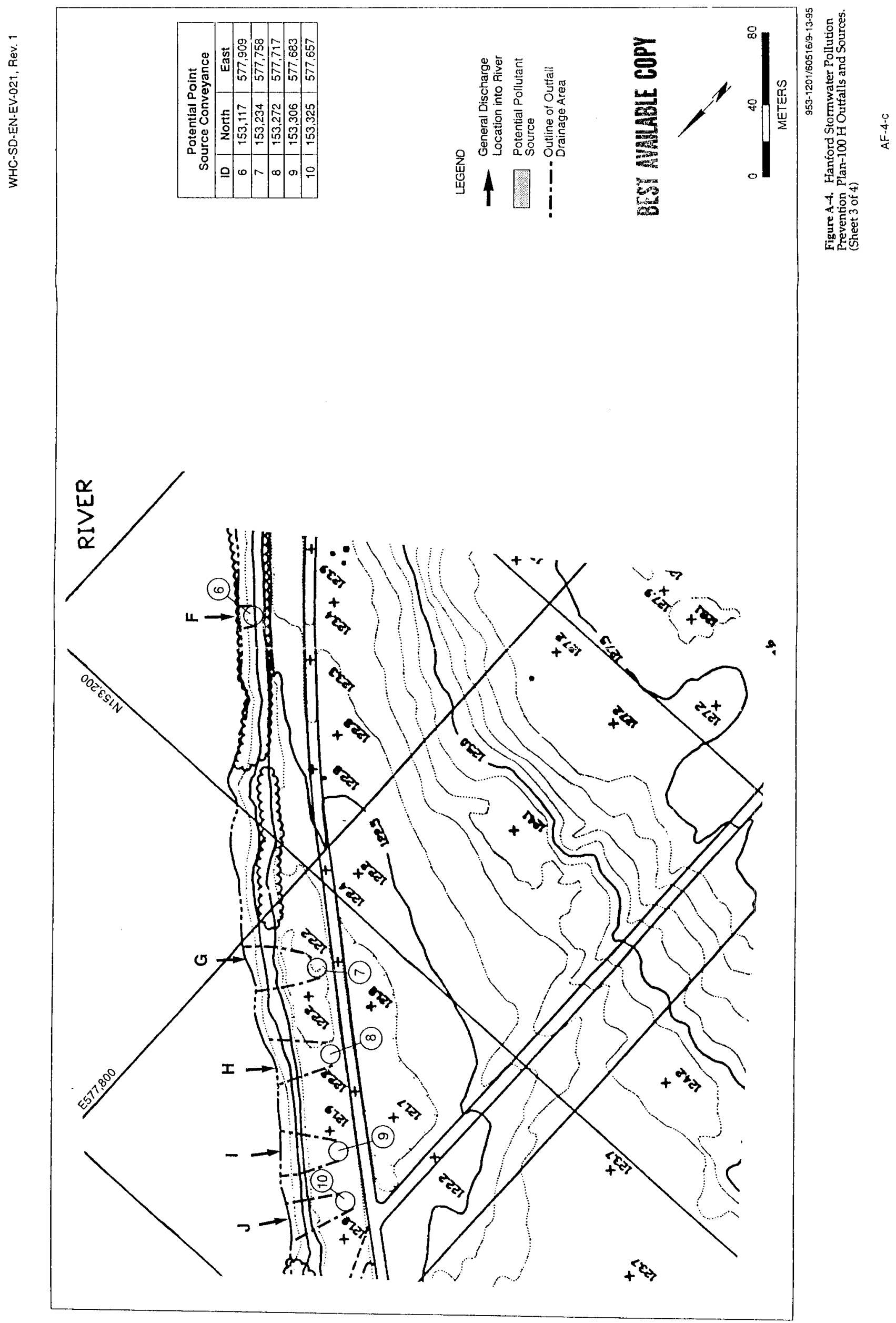




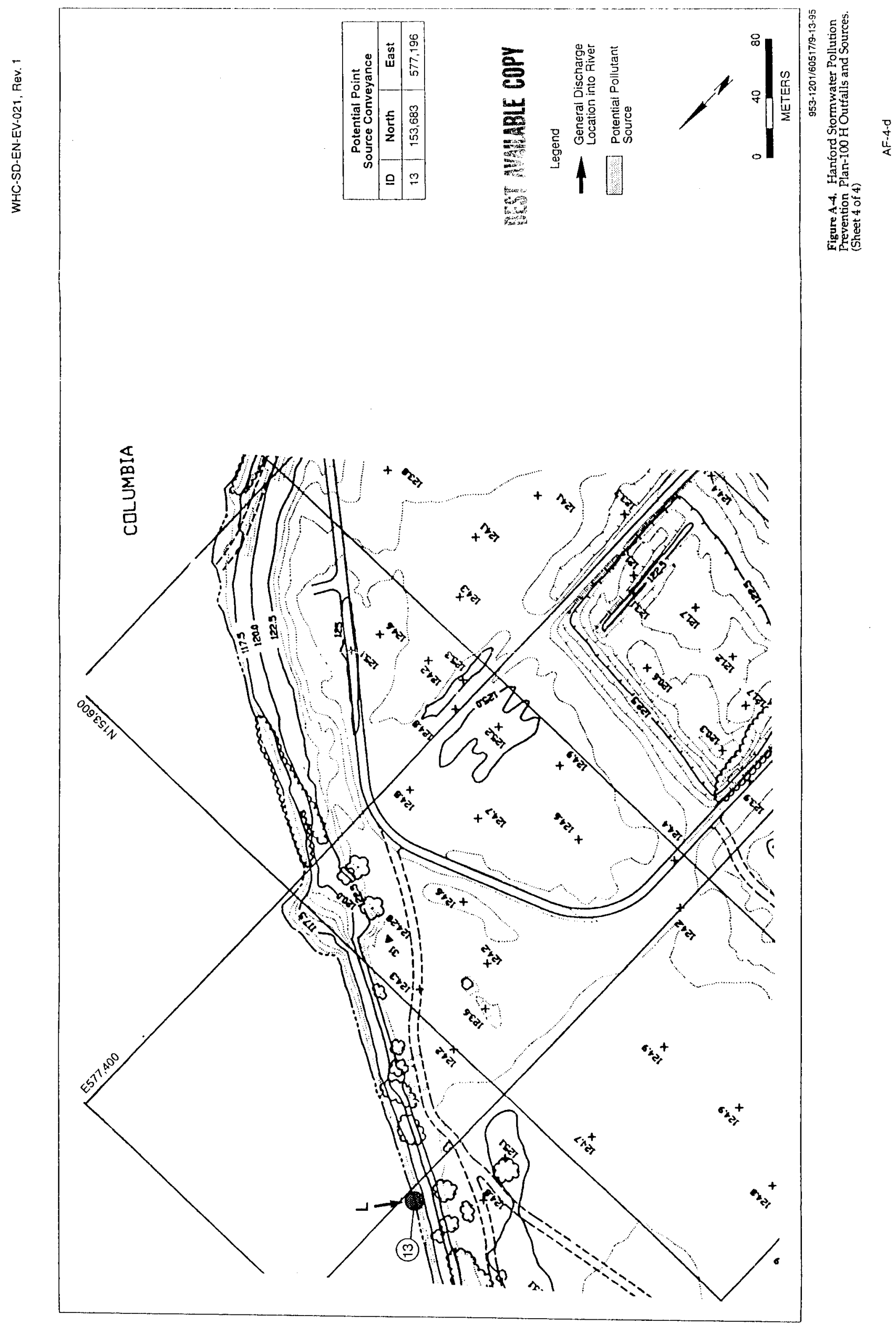




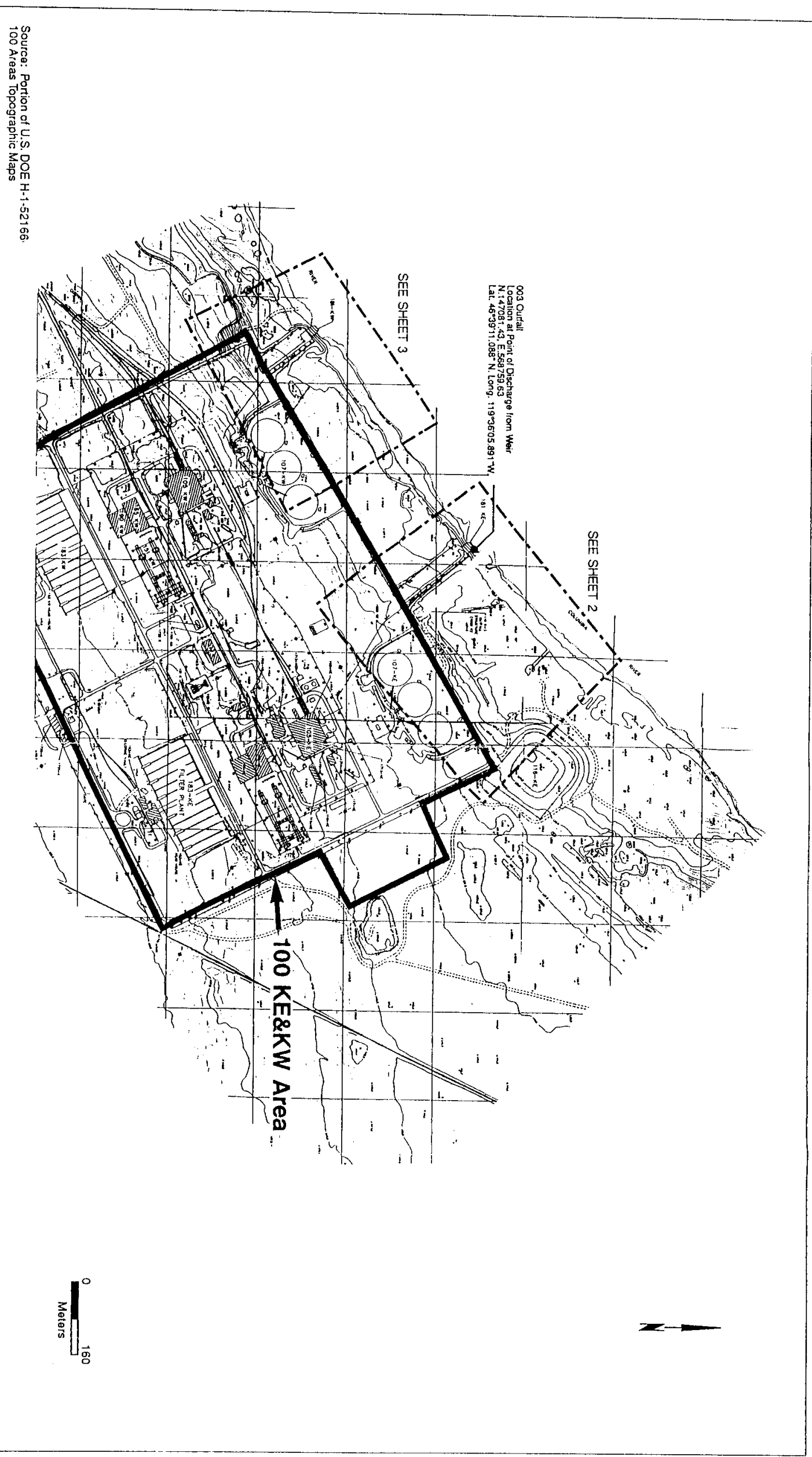




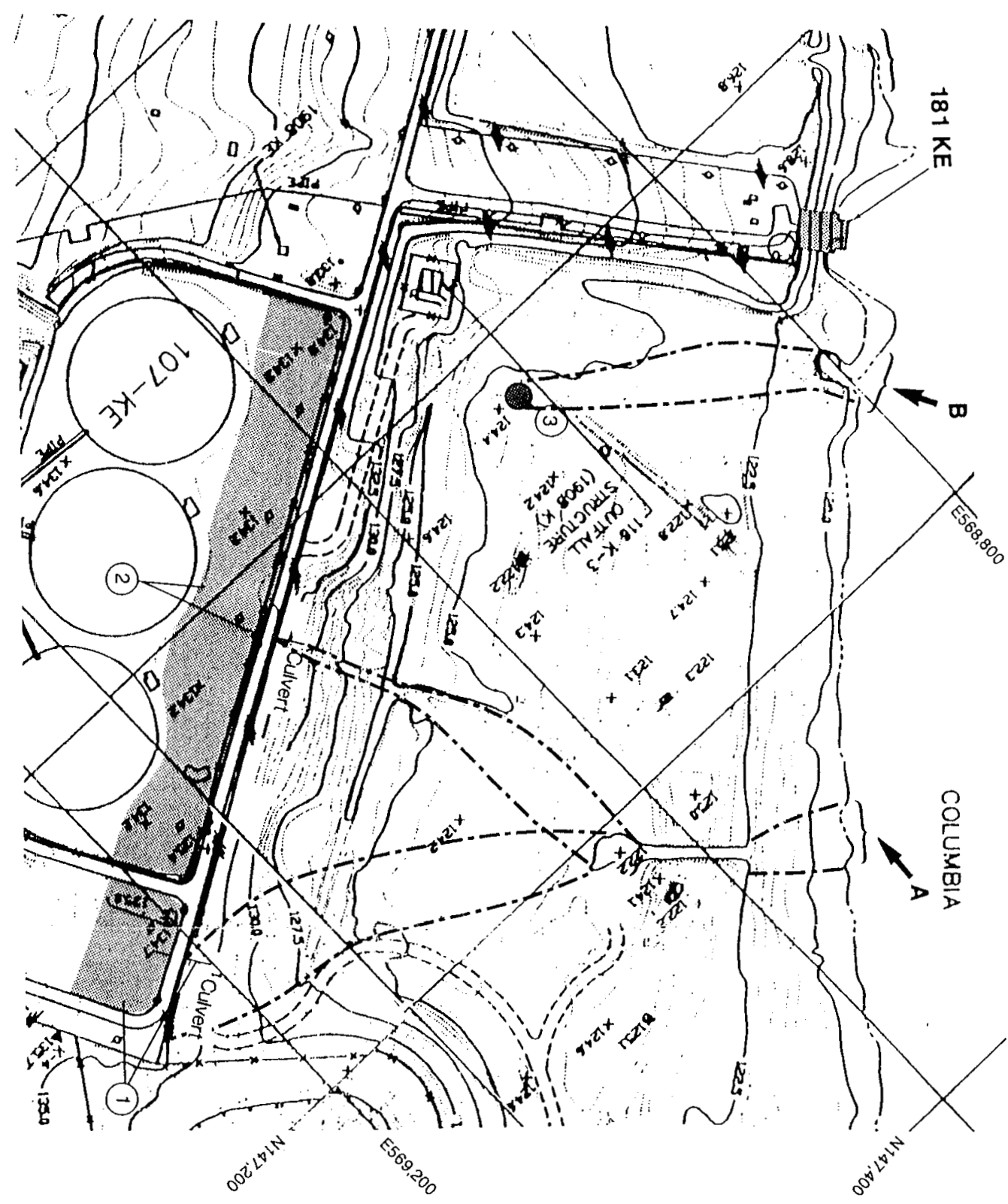

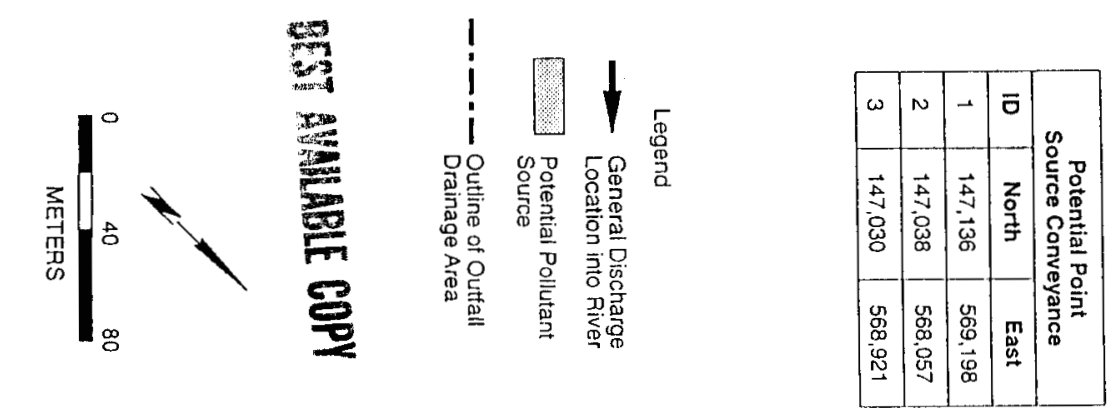



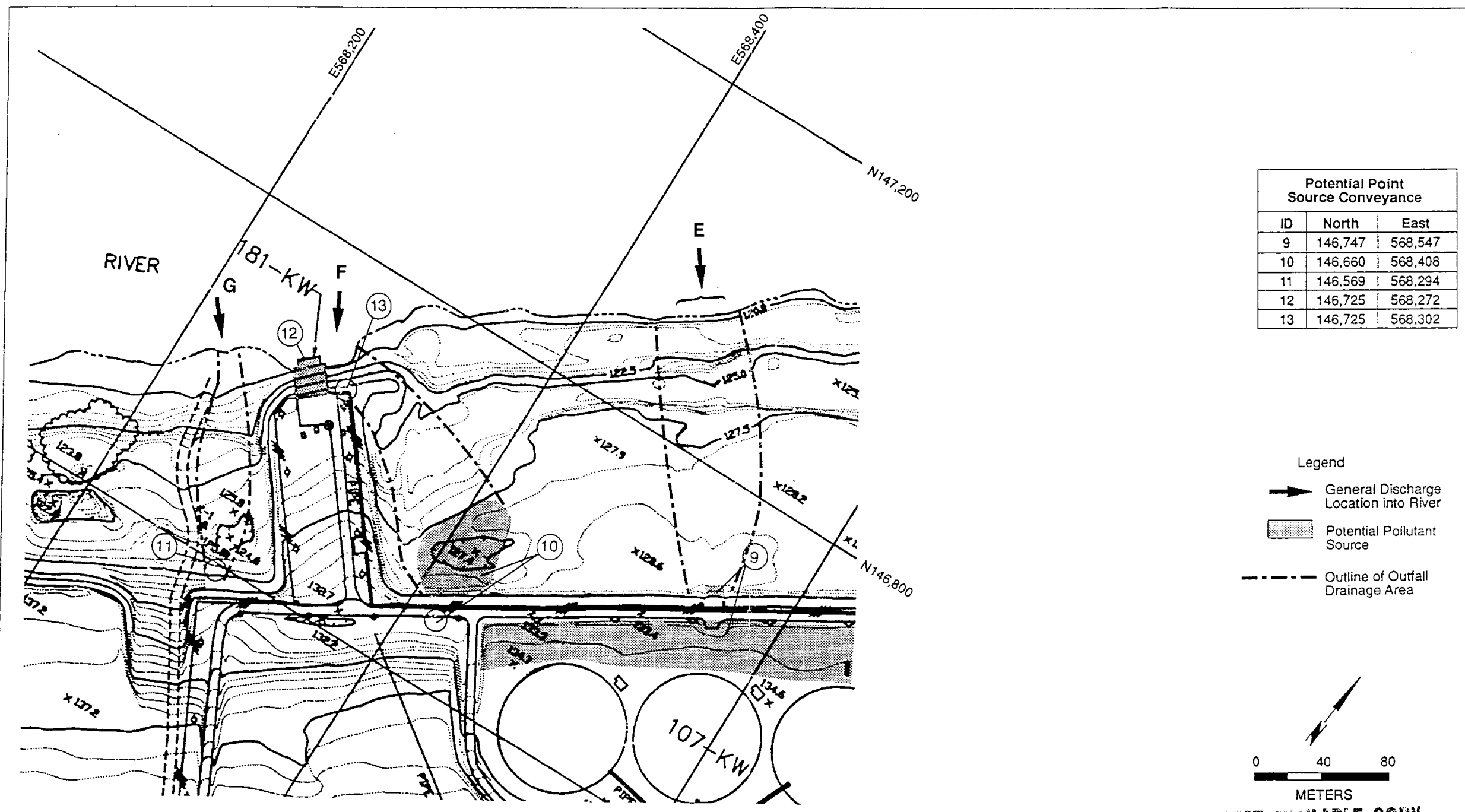

Legend

General Discharge Potential Pollutant Source

- - - - Outline of Outfal WEST EVIMABEE COPY

Figure A-5. Hanford Stormwater Pollution Prevention Plan-100 K West Outfalls and Sources. (Sheet 3 of 3 ) 


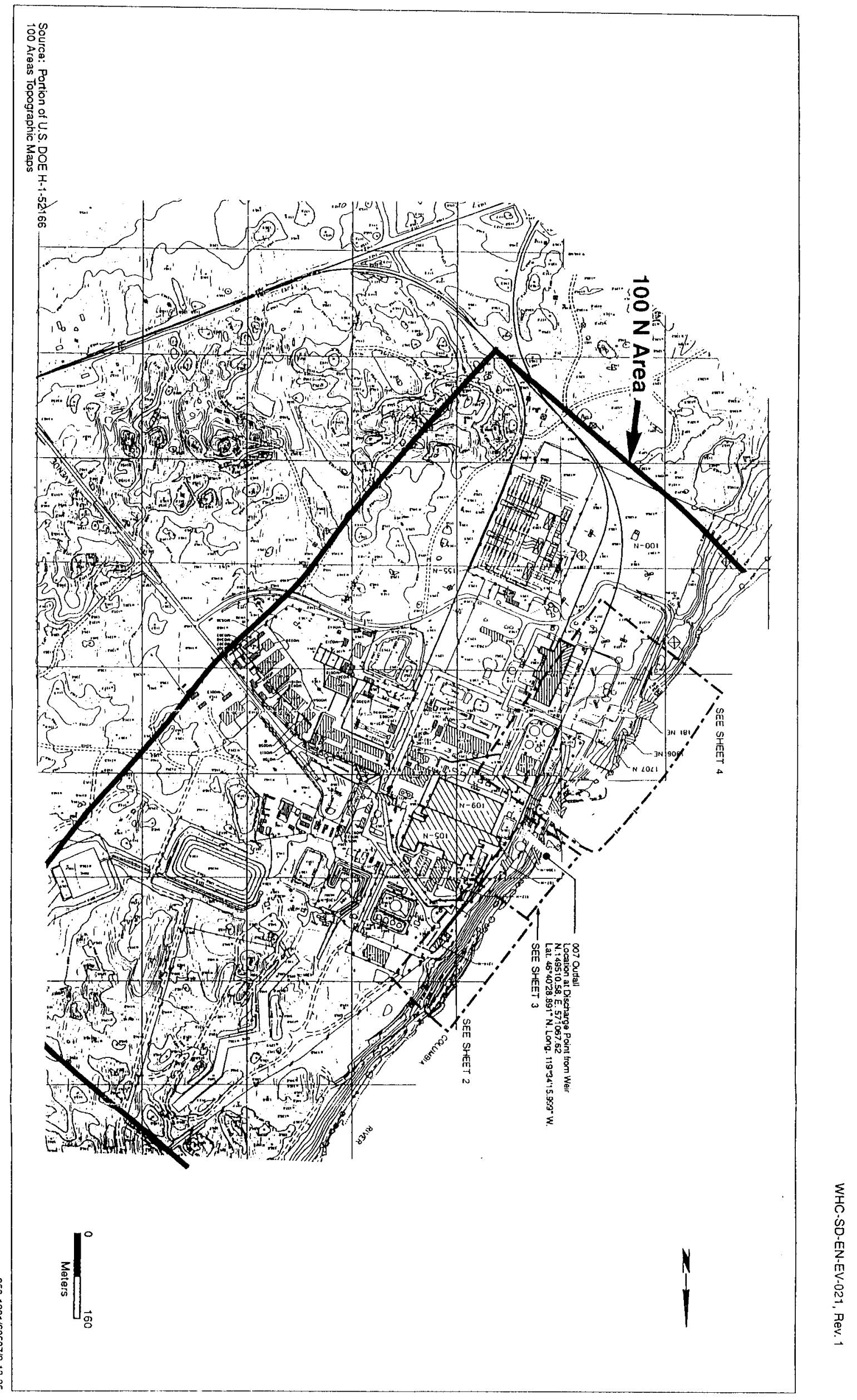




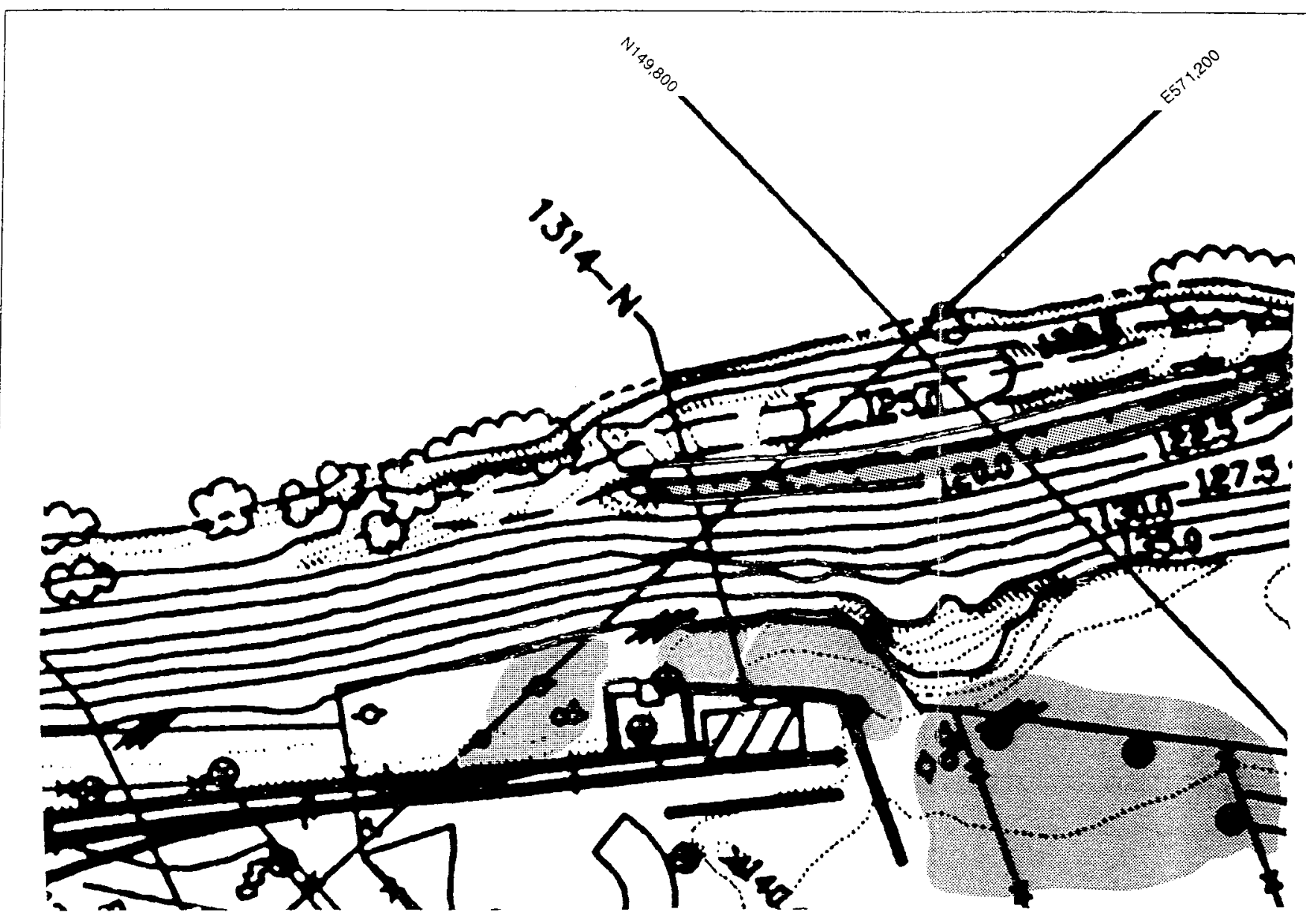

BEST WVALLABLE COPY

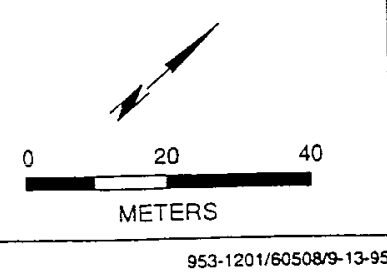




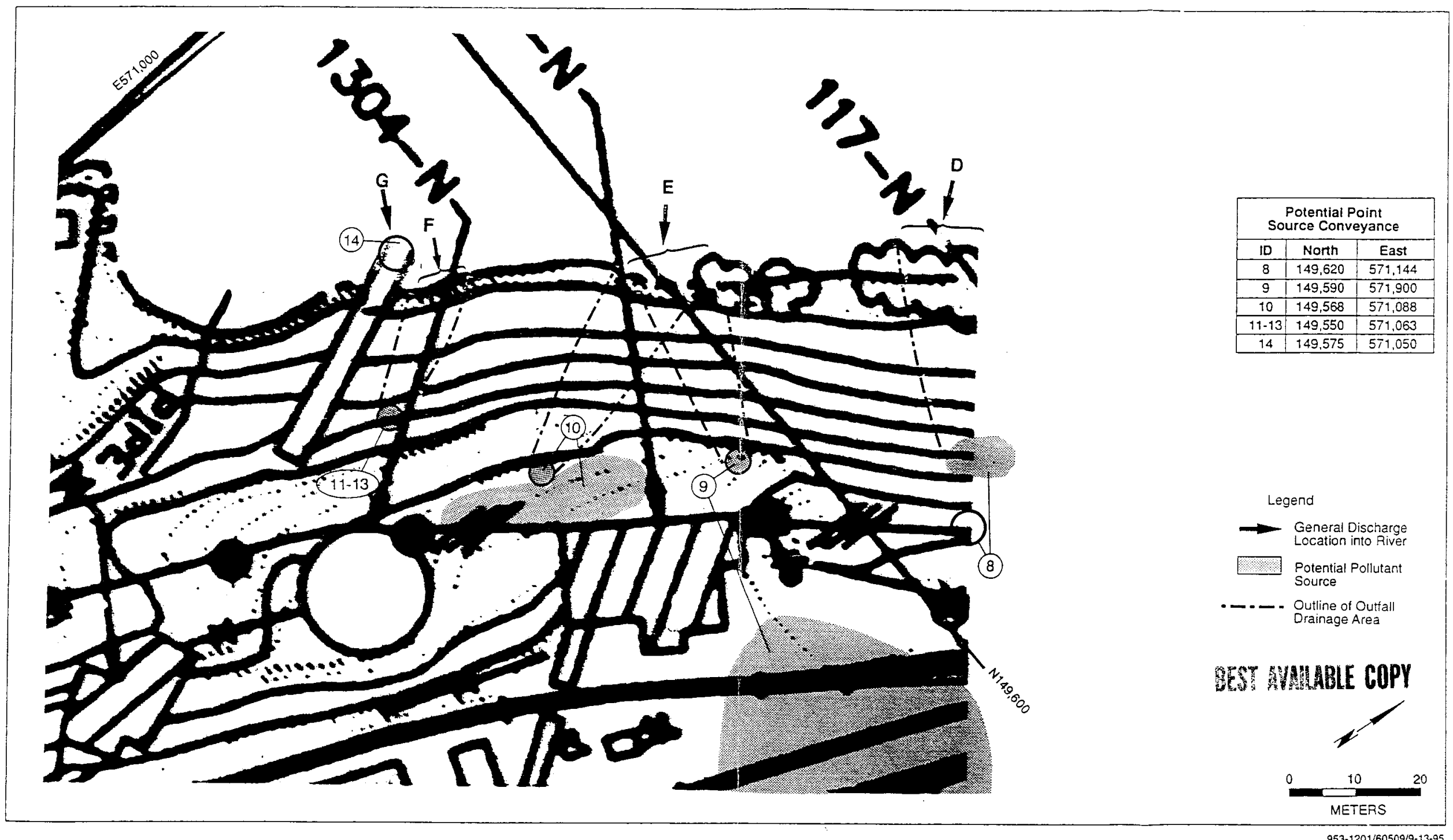

Figure A-6. Hanford Stormwater Pollution 

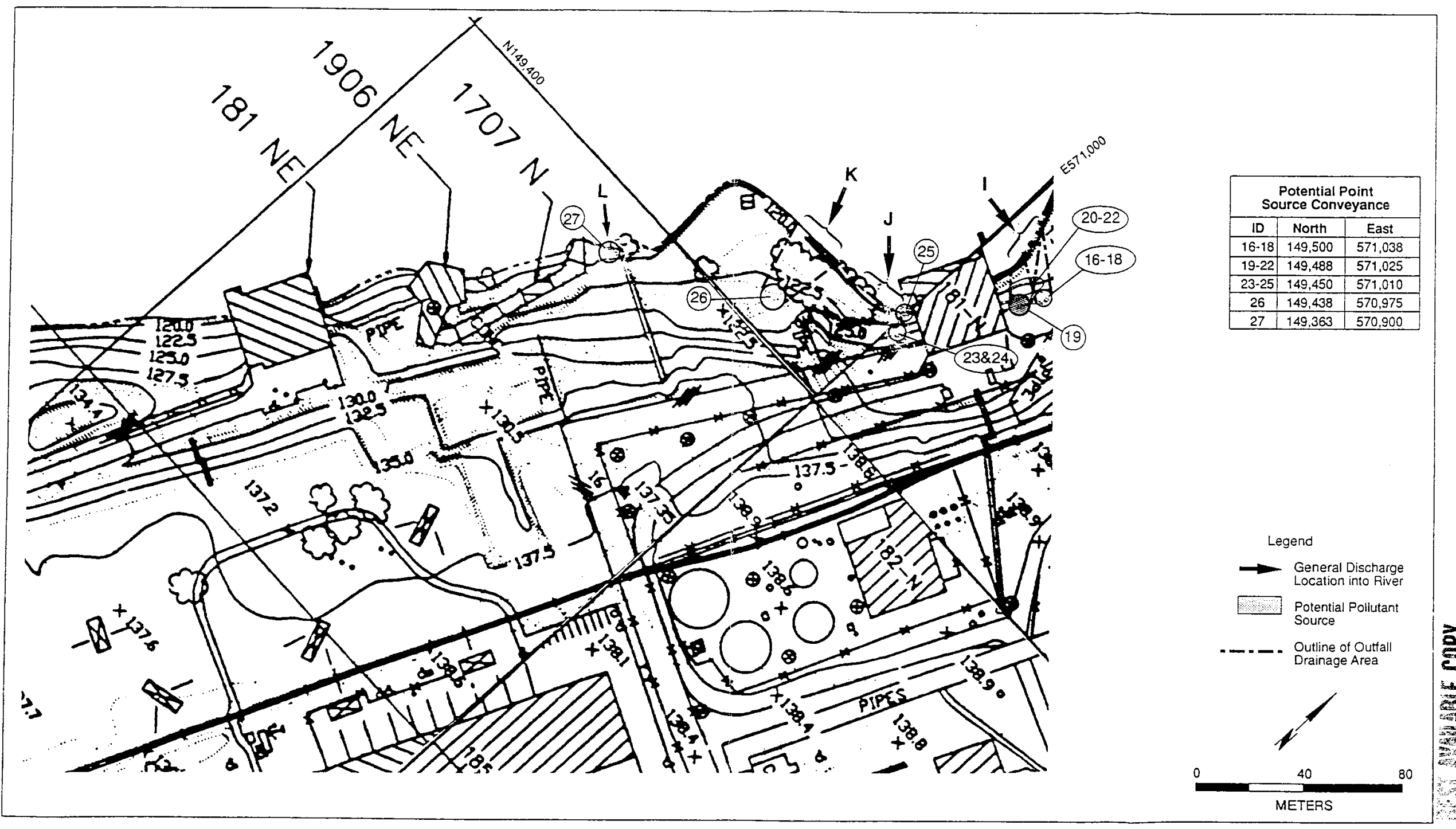

Figure A-6. Hanford Stormwater Pollution 


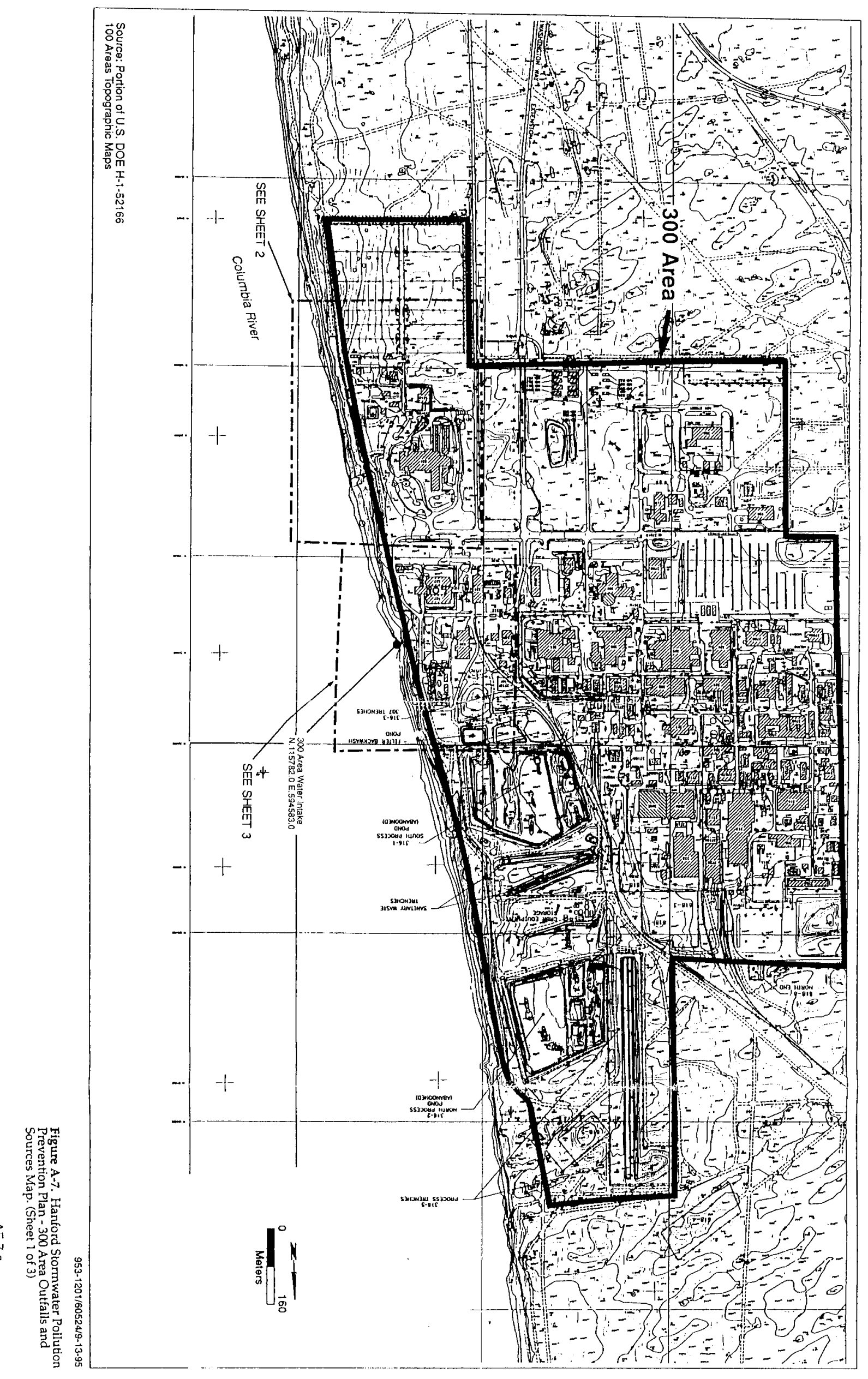




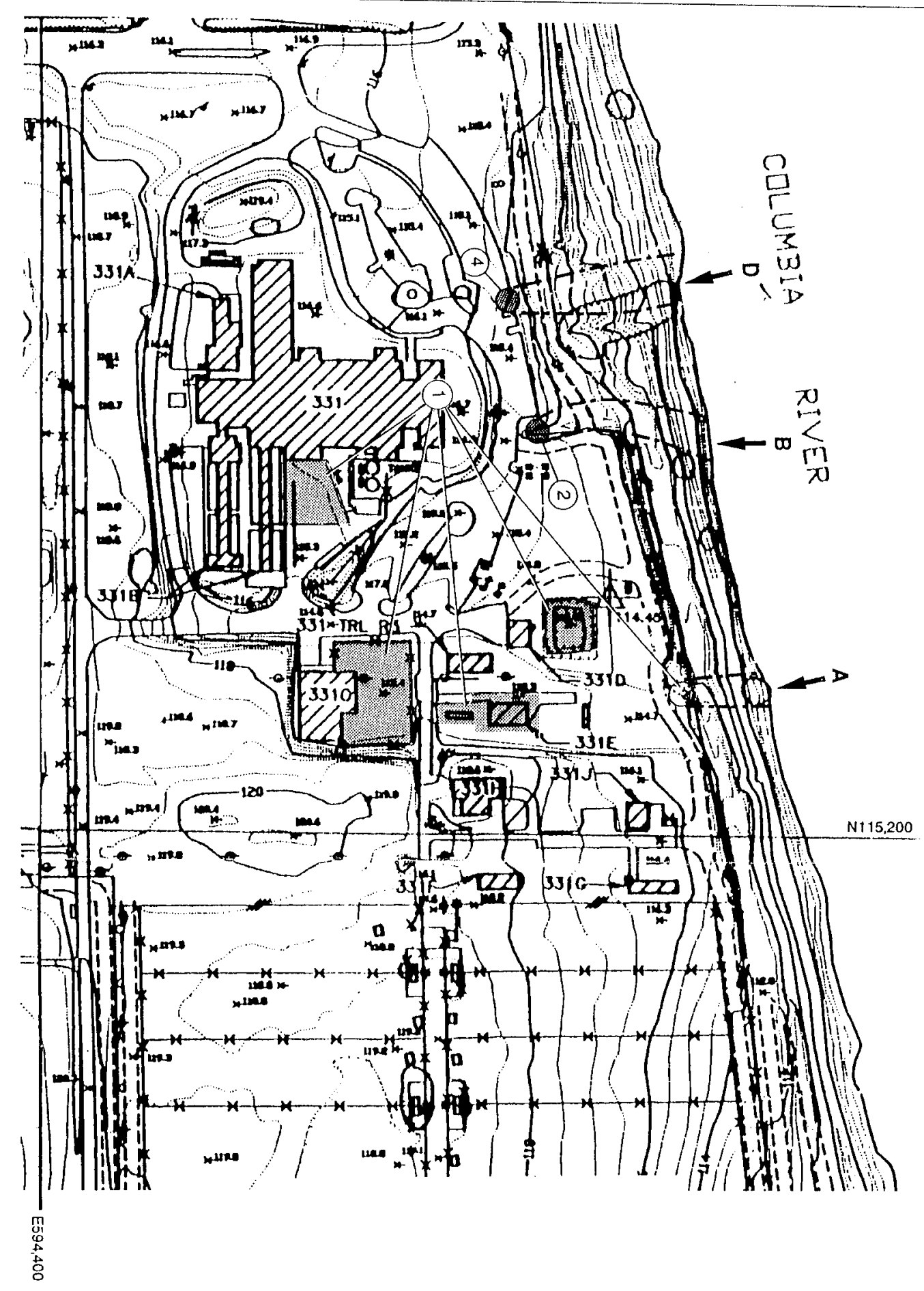

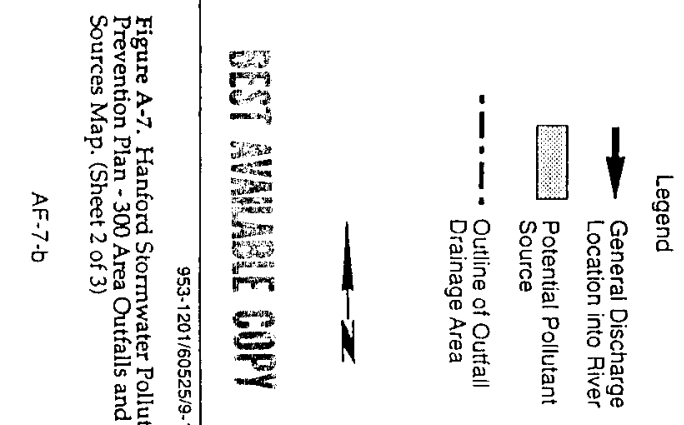

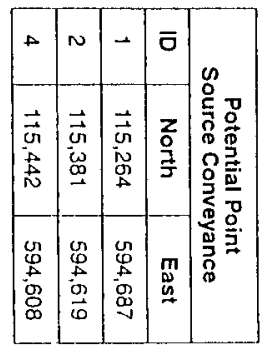



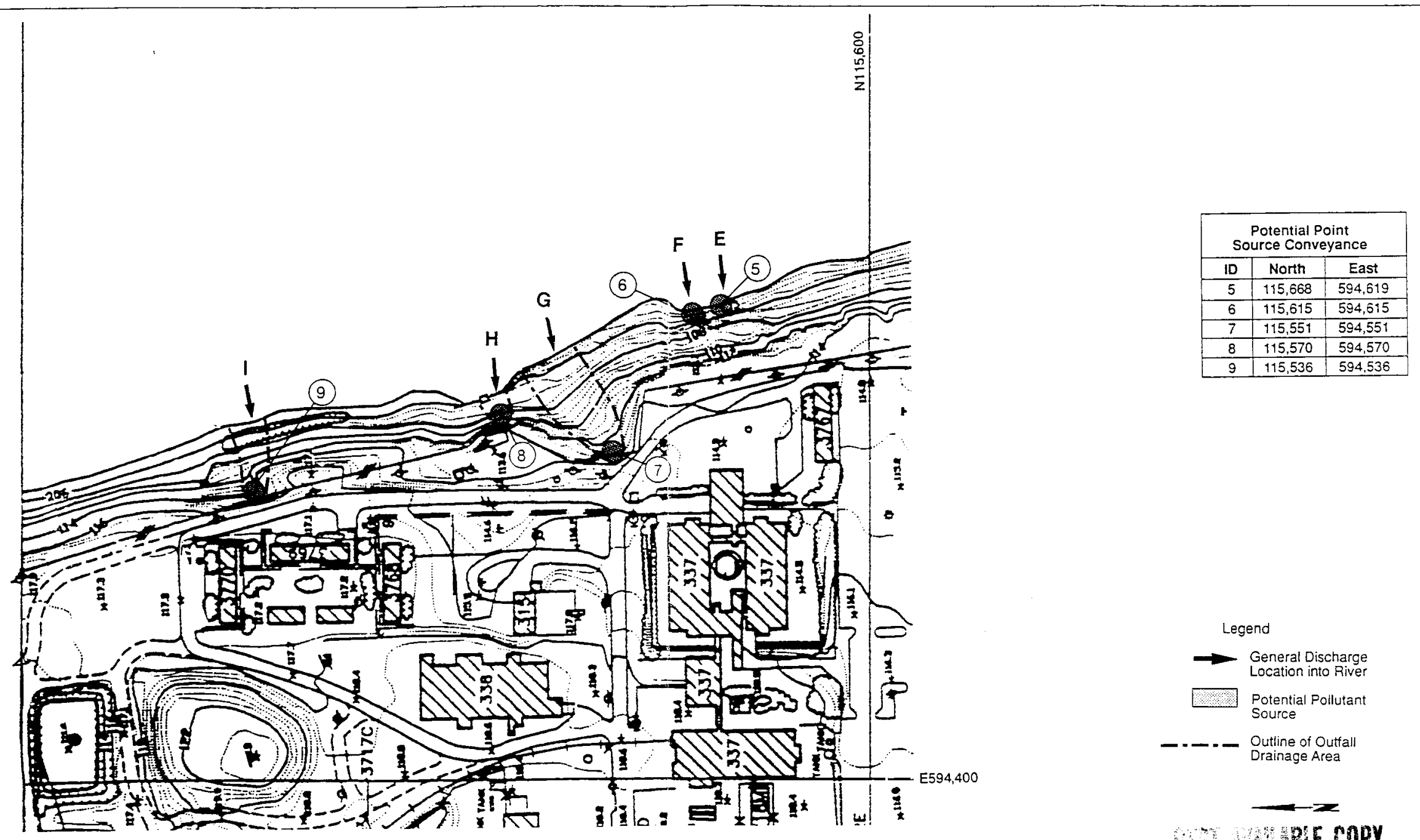

Legend

$\rightarrow$ General Discharge

Potential Poilutant

- - - - Outline of Outfall

Drana Are日

$\longrightarrow$

WW WWU BPIE COPY

953-1201/60527/9-13-95 
WHC-SD-EN-EV-021, Rev. 1

APPENDIX B

OUTFALI DESCRIPTION TABLES

$B T-i$ 


\section{SURVEY SUMMARY FOR THE 100-B AND 100-C AREAS}

\begin{tabular}{|c|c|c|c|c|c|}
\hline $\begin{array}{l}\text { Map } \\
\text { Reference } \\
\text { No. }\end{array}$ & $\begin{array}{l}\text { General } \\
\text { Discharge } \\
\text { Location } \\
\text { to River }\end{array}$ & $\begin{array}{l}\text { Potential } \\
\text { Point } \\
\text { Source } \\
\text { Conveyance }\end{array}$ & $\begin{array}{l}\text { Description/Current Status } \\
\text { Inspection Date: }\end{array}$ & $\begin{array}{l}\text { Potential } \\
\text { Pollutant } \\
\text { Sources }\end{array}$ & $\begin{array}{l}\text { Best Management } \\
\text { Practice(s) }\end{array}$ \\
\hline $\begin{array}{l}\text { Figure A-1, } \\
\text { Sheet } 2\end{array}$ & $A$ & 1 & $\begin{array}{l}\text { Storm water runoff would flow over } \\
\text { riprap to close proximity of the } \\
\text { river. The riprap was located in } \\
\text { the area of the 116-C-4 0utfall. } \\
\text { On the terrace above the riprap was } \\
\text { a roped-off area that was posted } \\
\text { "Danger - Keep Away." The riprap } \\
\text { created a channel toward the river } \\
\text { and was comprised of irregularly } \\
\text { shaped } 0.3 \text { to } 0.9 \text { meter (one to } \\
\text { three feet) diameter rocks. The } \\
\text { riprap was approximately six meters } \\
\text { (20 feet) wide and was moderately } \\
\text { sloped to the river. }\end{array}$ & None identified. & $\begin{array}{l}\text { It was determined no } \\
\text { pollutant source } \\
\text { exists, so no action } \\
\text { is necessary. }\end{array}$ \\
\hline
\end{tabular}


SURVEY SUMMARY FOR THE 100-B AND 100-C AREAS

\begin{tabular}{|c|c|c|c|c|c|}
\hline $\begin{array}{l}\text { Map } \\
\text { Reference } \\
\text { No. }\end{array}$ & $\begin{array}{l}\text { General } \\
\text { Discharge } \\
\text { Location } \\
\text { to River }\end{array}$ & $\begin{array}{c}\text { Potential } \\
\text { Point } \\
\text { Source } \\
\text { Conveyance }\end{array}$ & $\begin{array}{l}\text { Description/Current Status } \\
\text { Inspection Date: }\end{array}$ & $\begin{array}{l}\text { Potential } \\
\text { Pollutant } \\
\text { Sources }\end{array}$ & $\begin{array}{l}\text { Best Management } \\
\text { Practice(s) }\end{array}$ \\
\hline $\begin{array}{l}\text { Figure } A-1, \\
\text { Sheet } 2\end{array}$ & B & 2 & $\begin{array}{l}\text { Storm water runoff would flow over } \\
\text { riprap to within meters of the } \\
\text { river. The riprap is in the area } \\
\text { of the } 116-\mathrm{B}-8 \text { Outfall which has } \\
\text { been demolished and covered with } \\
\text { dirt. Formerly known as } 1904-\mathrm{B} \text {. On } \\
\text { the terrace above the riprap was a } \\
9 \times 9 \text { meter ( } 30 \times 30 \text { foot) roped- } \\
\text { off area that is posted "Surface } \\
\text { Contamination." This site is } \\
\text { identified in the Quarterly } \\
\text { Environmental Radiological Survey } \\
\text { Summary (WHC-SP-0665-11). The } \\
\text { riprap is comprised of irregularly } \\
\text { shaped 0.3 to } 0.9 \text { meter (one to } \\
\text { three feet) diameter rocks. The } \\
\text { riprap and extensions of the bank } \\
\text { created several channels that came } \\
\text { together half-way down the bank to } \\
\text { form a single riprap channel } \\
\text { approximately } 12 \text { meters (40 feet) } \\
\text { wide that led to the river. }\end{array}$ & $\begin{array}{l}\text { Radiological } \\
\text { surface } \\
\text { contamination } \\
\text { area. }\end{array}$ & $\begin{array}{l}\text { This outfall has } \\
\text { been demolished and } \\
\text { covered with dirt. } \\
\text { There is no access } \\
\text { to the river. No } \\
\text { further action is } \\
\text { planned at this } \\
\text { time. }\end{array}$ \\
\hline
\end{tabular}


SURVEY SUMMARY FOR THE 100-B AND 100-C AREAS

\begin{tabular}{|c|c|c|c|c|c|}
\hline $\begin{array}{c}\text { Map } \\
\text { Reference } \\
\text { No. }\end{array}$ & $\begin{array}{l}\text { General } \\
\text { Discharge } \\
\text { Location } \\
\text { to River }\end{array}$ & $\begin{array}{l}\text { Potential } \\
\text { Point } \\
\text { Source } \\
\text { Conveyance } \\
\end{array}$ & $\begin{array}{l}\text { Description/Current Status } \\
\text { Inspection Date: }\end{array}$ & $\begin{array}{l}\text { Potential } \\
\text { Pollutant } \\
\text { Sources }\end{array}$ & $\begin{array}{l}\text { Best Management } \\
\text { Practice(s) }\end{array}$ \\
\hline $\begin{array}{l}\text { Figure } A-1, \\
\text { Sheet } 3\end{array}$ & c & 3 & $\begin{array}{l}\text { At the top of the gently-to- } \\
\text { moderate sloped bank, above the } \\
\text { flume, is the concrete outfall } \\
\text { structure. This area is labelled } \\
\text { on selected maps as the "116-B-7 } \\
\text { Outfall." It is fenced and posted } \\
\text { as "Surface Contamination". This } \\
\text { site is identified in the Quarterly } \\
\text { Environmental Radiological Survey } \\
\text { Summary (WHC-SP-0665-11). The } \\
\text { configuration of the outfall } \\
\text { structure is such that storm water } \\
\text { coming in contact with the interior } \\
\text { of the structure would not overflow } \\
\text { to the bank and reach the river. }\end{array}$ & $\begin{array}{l}\text { Radiological } \\
\text { surface } \\
\text { contamination } \\
\text { area. }\end{array}$ & $\begin{array}{l}\text { There is no pathway } \\
\text { for the surface } \\
\text { contamination to } \\
\text { reach the river, so } \\
\text { no immediate action } \\
\text { is planned. }\end{array}$ \\
\hline $\begin{array}{l}\text { Figure } A-1 \text {, } \\
\text { Sheet } 3\end{array}$ & $\mathrm{E}$ & 5 & $\begin{array}{l}\text { Stormwater runoff would come in } \\
\text { contact with Building 181-B and } \\
\text { surrounding materials. The north } \\
\text { side of the facility is in direct } \\
\text { contact with the river. A } \\
\text { gravel/asphalt parking lot is } \\
\text { located on the south side of the } \\
\text { facility. Stormwater could drain to } \\
\text { the river from this parking lot } \\
\text { thru a hole in a concrete retaining } \\
\text { wall which extends from the east } \\
\text { side of the 181-B Building. } \\
\text { Transformers located to the } \\
\text { southeast of Building 181-B have } \\
\text { secondary containment that drains } \\
\text { to a septic tank. }\end{array}$ & None identified. & $\begin{array}{l}\text { No action is } \\
\text { required. }\end{array}$ \\
\hline
\end{tabular}




\section{SURVEY SUMMARY OF 100-D AND 100-DR AREAS}

\begin{tabular}{|c|c|c|c|c|c|}
\hline $\begin{array}{c}\text { Map } \\
\text { Reference } \\
\text { No. }\end{array}$ & $\begin{array}{c}\text { General } \\
\text { Discharge } \\
\text { Location } \\
\text { to River } \\
\end{array}$ & $\begin{array}{l}\text { Potential } \\
\text { Point } \\
\text { Source } \\
\text { Conveyance } \\
\end{array}$ & Description/Current Status & $\begin{array}{l}\text { Potential } \\
\text { Pollutant } \\
\text { Sources }\end{array}$ & $\begin{array}{l}\text { Best Management } \\
\text { Practice(s) }\end{array}$ \\
\hline $\begin{array}{c}\text { Figure } A-2, \\
\text { Sheet } 2\end{array}$ & A & 1 & $\begin{array}{l}\text { A concrete flume, which is labelled } \\
\text { on selected maps as "116-DR-5," } \\
\text { extends from the bank into the } \\
\text { river. The flume is surrounded by } \\
\text { natural vegetation and river rock. } \\
\text { The concrete.walls would channel } \\
\text { storm water flow into the river. } \\
\text { The river bank is moderately } \\
\text { sloped. }\end{array}$ & None identified. & $\begin{array}{l}\text { No action is planned } \\
\text { because there is no } \\
\text { source of } \\
\text { contamination. }\end{array}$ \\
\hline $\begin{array}{c}\text { Figure A-2, } \\
\text { Sheet } 2\end{array}$ & B & 2 & $\begin{array}{l}\text { A concrete flume, which is labelled } \\
\text { on selected maps as "116-D-5" } \\
\text { outfall, formerly called 1904-D, } \\
\text { extends from the bank into the } \\
\text { river. The concrete walls would } \\
\text { channel storm water flow into the } \\
\text { river. At the river's edge, } \\
\text { concrete has been crudely poured } \\
\text { into the flume in an apparent } \\
\text { attempt to cover the flume and } \\
\text { block flow. The flume is } \\
\text { surrounded by natural vegetation } \\
\text { and river rock. The river bank is } \\
\text { moderately sloped. This area is } \\
\text { posted "Underground Radioactive } \\
\text { Material". }\end{array}$ & $\begin{array}{l}\text { Underground } \\
\text { Radioactive } \\
\text { material. }\end{array}$ & $\begin{array}{l}\text { There is no source } \\
\text { of contamination } \\
\text { which storm runoff } \\
\text { can carry to the } \\
\text { river. No action is } \\
\text { planned. }\end{array}$ \\
\hline
\end{tabular}


SURVEY SUMMARY OF 100-D AND 100-DR AREAS

\begin{tabular}{|c|c|c|c|c|c|}
\hline $\begin{array}{c}\text { Map } \\
\text { Reference } \\
\text { No. }\end{array}$ & $\begin{array}{c}\text { General } \\
\text { Discharge } \\
\text { Location } \\
\text { to River } \\
\end{array}$ & $\begin{array}{c}\text { Potential } \\
\text { Point } \\
\text { Source } \\
\text { Conveyance } \\
\end{array}$ & Description/Current Status & $\begin{array}{c}\text { Potential } \\
\text { Pollutant } \\
\text { Sources }\end{array}$ & $\begin{array}{l}\text { Best Management } \\
\text { Practice(s) }\end{array}$ \\
\hline $\begin{array}{l}\text { Figure A-2, } \\
\text { Sheet } 3\end{array}$ & c & 3 & $\begin{array}{l}\text { Stormwater runoff would come in } \\
\text { contact with Building } 181-0 \text { and } \\
\text { surrounding materials. The north } \\
\text { side of the building is in direct } \\
\text { contact with the river. A gravel } \\
\text { parking lot is located on the south } \\
\text { side of the facility. Electrical } \\
\text { transformers are located on the } \\
\text { south side of Building 181-D. Two } \\
\text { large transformers are classified } \\
\text { as "PCB Contaminated" (50-499 ppm } \\
\text { PCBs) and are provided with } \\
\text { secondary containment. Four } \\
\text { smaller non PCB transformers do not } \\
\text { have secondary containment, but due } \\
\text { to their location and condition } \\
\text { would not be expected to be a } \\
\text { pollutant source. }\end{array}$ & None identified. & No action required. \\
\hline
\end{tabular}


SURVEY SUMMARY FOR 100-F AREA

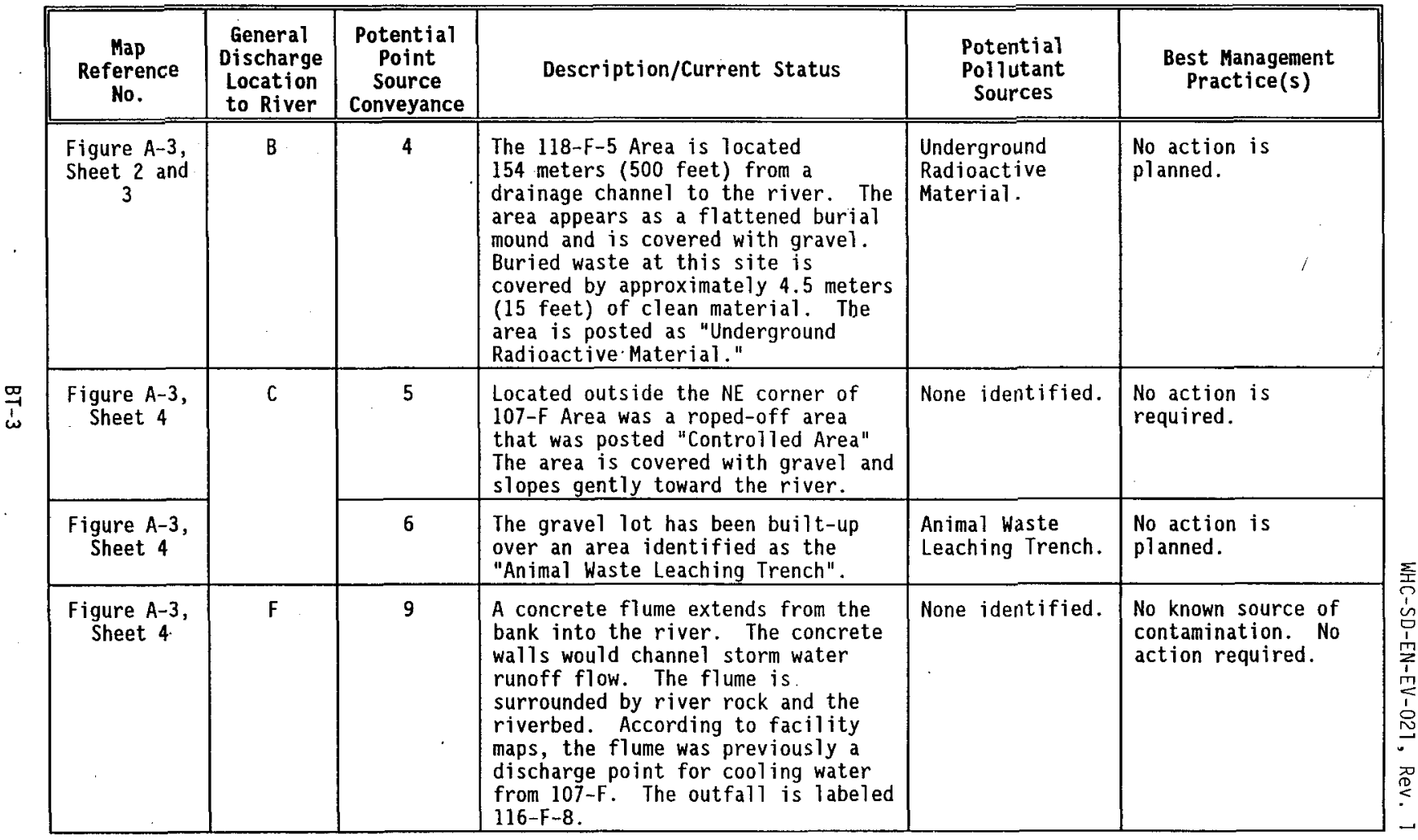




\section{SURVEY SUMMARY FOR 100-F AREA}

\begin{tabular}{|c|c|c|c|c|c|}
\hline $\begin{array}{l}\text { Map } \\
\text { Reference } \\
\text { No. }\end{array}$ & $\begin{array}{l}\text { General } \\
\text { Discharge } \\
\text { Location } \\
\text { to River } \\
\end{array}$ & $\begin{array}{l}\text { Potential } \\
\text { Point } \\
\text { Source } \\
\text { Conveyance } \\
\end{array}$ & Description/Current Status & $\begin{array}{l}\text { Potential } \\
\text { Pollutant } \\
\text { Sources }\end{array}$ & $\begin{array}{l}\text { Best Management } \\
\text { Practice(s) }\end{array}$ \\
\hline $\begin{array}{l}\text { Figure } A-3 \text {, } \\
\text { Sheet } 4\end{array}$ & $\mathbf{G}$ & 11 & $\begin{array}{l}\text { A concrete flume extends from the } \\
\text { riverbank into the river. The } \\
\text { concrete walls would channel } \\
\text { stormwater runoff flow. The flume, } \\
\text { which is labeled as the "PNL } \\
\text { Outfall" on some site maps, is } \\
\text { surrounded by river rock and } \\
\text { riverbed. The outfall is labeled } \\
116-F-9 \text {. }\end{array}$ & None identified & $\begin{array}{l}\text { No known source of } \\
\text { contamination. No } \\
\text { action. }\end{array}$ \\
\hline $\begin{array}{l}\text { Figure } A-3, \\
\text { sheet } 5\end{array}$ & $H$ & 12 & $\begin{array}{l}\text { An open } 20 \text { centimeter (eight inch) } \\
\text { diameter vertical pipe extends from } \\
\text { the ground in an area to the north } \\
\text { of the demolished 181-F Intake } \\
\text { Facility. The area surrounding the } \\
\text { pipe is covered by rock and natural } \\
\text { vegetation. The pipe was probably } \\
\text { once connected to the demolished } \\
\text { 181-F Intake Facility. }\end{array}$ & None identified. & $\begin{array}{l}\text { Given the inactive } \\
\text { status and no } \\
\text { process operations } \\
\text { at } 100-F \text {, there } \\
\text { appears to be no } \\
\text { source that could } \\
\text { discharge from this } \\
\text { pipe. No action is } \\
\text { planned. }\end{array}$ \\
\hline $\begin{array}{l}\text { Figure } A-3, \\
\text { Sheet } 5\end{array}$ & & 13 & $\begin{array}{l}\text { Another open } 20 \text { centimeter } \\
\text { (eight inch) diameter vertical pipe } \\
\text { extends from the ground in an area } \\
\text { to the north of the demol ished } \\
\text { 181-F Intake Facility. The area } \\
\text { surrounding the pipe is covered by } \\
\text { rock and natural vegetation. The } \\
\text { pipe was probably once connected to } \\
\text { the demolished 181-F Intake } \\
\text { Facility. }\end{array}$ & None identified. & $\begin{array}{l}\text { Given the inactive } \\
\text { status and no } \\
\text { process operations } \\
\text { at } 100-F \text {, there } \\
\text { appears to be no } \\
\text { source that could } \\
\text { discharge from this } \\
\text { pipe. No action is } \\
\text { planned. }\end{array}$ \\
\hline
\end{tabular}




\section{SURVEY SUMMARY FOR 100-F AREA}

\begin{tabular}{|c|c|c|c|c|c|}
\hline $\begin{array}{c}\text { Map } \\
\text { Referrence } \\
\text { No. }\end{array}$ & $\begin{array}{c}\text { General } \\
\text { Discharge } \\
\text { Location } \\
\text { to River } \\
\end{array}$ & $\begin{array}{c}\text { Potential } \\
\text { Point } \\
\text { Source } \\
\text { Conveyance } \\
\end{array}$ & Description/Current Status & $\begin{array}{c}\text { Potential } \\
\text { Pollutant } \\
\text { Sources }\end{array}$ & $\begin{array}{l}\text { Best Management } \\
\text { Practice(s) }\end{array}$ \\
\hline $\begin{array}{c}\text { Figure } A-3 \text {, } \\
\text { Sheet } 6 \\
!\end{array}$ & $\mathrm{J}$ & 15 & $\begin{array}{l}\text { Storm water runoff drains to the } \\
\text { river via a paved boat ramp, which } \\
\text { is adjacent to the WBF-l and } \\
\text { WBF-2 Buildings. The area is } \\
\text { moderately sloped and consists of } \\
\text { parking and roadways that are } \\
\text { gravel. This outfall results from } \\
\text { non-industrial sources. }\end{array}$ & None identified. & $\begin{array}{l}\text { No action is } \\
\text { planned. }\end{array}$ \\
\hline
\end{tabular}

四
$\mathbf{\omega}$
i 


\section{SURVEY SUMMARY FOR THE 100-H AREA}

\begin{tabular}{|c|c|c|c|c|c|}
\hline $\begin{array}{c}\text { Map } \\
\text { Reference } \\
\text { No. }\end{array}$ & $\begin{array}{l}\text { General } \\
\text { Discharge } \\
\text { Location } \\
\text { to River } \\
\end{array}$ & $\begin{array}{l}\text { Potential } \\
\text { Point } \\
\text { Source } \\
\text { Conveyance } \\
\end{array}$ & Description/Current status & $\begin{array}{l}\text { Potential } \\
\text { Pollutant } \\
\text { Sources }\end{array}$ & $\begin{array}{l}\text { Best Management } \\
\text { Practice(s) }\end{array}$ \\
\hline $\begin{array}{l}\text { Figure } A-4, \\
\text { Sheet } 2\end{array}$ & A & 1 & $\begin{array}{l}\text { A } 13 \text { centimeter (five inch) } \\
\text { diameter pipe is present that would } \\
\text { discharge to a } 3 \text {-sided concrete dry } \\
\text { well. A natural drainage channel } \\
\text { is visible that extends from the } \\
\text { dry well to the river. The area is } \\
\text { gently sloped with dirt, river } \\
\text { rocks and natural vegetation, which } \\
\text { includes a couple of trees. } \\
\text { Believed to be a Hanford Irrigation } \\
\text { District weir box left from the } \\
\text { pre-Manhattan Project era. }\end{array}$ & None identified. & $\begin{array}{l}\text { No surface or } \\
\text { process source } \\
\text { exists today. No } \\
\text { action required. }\end{array}$ \\
\hline $\begin{array}{l}\text { Figure A-4, } \\
\text { Sheet } 2\end{array}$ & $\mathrm{C}$ & 3 & $\begin{array}{l}\text { An open } 30 \text { centimeter ( } 12 \text { inch) } \\
\text { diameter pipe is embedded in a } \\
\text { concrete square and is located at } \\
\text { the top of the river bank. It has } \\
\text { been identified as a culvert } \\
\text { draining the upland side of the } \\
\text { adjacent road. The upper portion } \\
\text { of the bank has a natural ravine } \\
\text { that extends from the head of the } \\
\text { pipe. The upper portion of the } \\
\text { bank is steeply sloped and the } \\
\text { lower portion is moderately sloped } \\
\text { toward the river. The area is } \\
\text { covered with river rock and natural } \\
\text { vegetation. }\end{array}$ & None identified. & $\begin{array}{l}\text { No contamination is } \\
\text { evident in the area. } \\
\text { No action is } \\
\text { required. }\end{array}$ \\
\hline
\end{tabular}


SURVEY SUMMARY FOR THE 100-H AREA

\begin{tabular}{|c|c|c|c|c|c|}
\hline $\begin{array}{l}\text { Map } \\
\text { Reference } \\
\text { No. }\end{array}$ & $\begin{array}{l}\text { General } \\
\text { Discharge } \\
\text { Location } \\
\text { to River }\end{array}$ & $\begin{array}{l}\text { Potential } \\
\text { Point } \\
\text { Source } \\
\text { Conveyance }\end{array}$ & Description/Current Status & $\begin{array}{l}\text { Potential } \\
\text { Pollutant } \\
\text { Sources }\end{array}$ & $\begin{array}{l}\text { Best Management } \\
\text { Practice(s) }\end{array}$ \\
\hline $\begin{array}{c}\text { Figure A-4, } \\
\text { Sheet } 2\end{array}$ & 0 & 4 & $\begin{array}{l}\text { Storm water runoff would flow over } \\
\text { the remnants of the demolished } \\
116-\mathrm{H}-5 \text { structure. The remnants } \\
\text { include concrete steps and large } \\
\text { concrete blocks. Additional rock } \\
\text { have been placed as riprap on the } \\
\text { slope. The bank is moderately } \\
\text { sloped until the steep wall of the } \\
\text { large concrete blocks. Below the } \\
\text { concrete blocks, the bank is } \\
\text { relatively flat. }\end{array}$ & Sediment. & $\begin{array}{l}\text { Riprap acts as BMP } \\
\text { to decrease runoff } \\
\text { velocity and } \\
\text { stabilize slope. No } \\
\text { further action is } \\
\text { planned. There is } \\
\text { no source of } \\
\text { contamination. }\end{array}$ \\
\hline $\begin{array}{c}\text { Figure } A-4, \\
\text { Sheet } 2\end{array}$ & $E$ & 5 & $\begin{array}{l}\text { Storm water runoff would flow over } \\
\text { the riprap to within feet of the } \\
\text { river. According to the maps, the } \\
\text { riprap was probably placed over the } \\
\text { remnants of the demolished } 116-\mathrm{H}-5 \text {. } \\
\text { The riprap is moderately sloped } \\
\text { with virtually no vegetation. }\end{array}$ & Sediment. & $\begin{array}{l}\text { No action is } \\
\text { necessary. Riprap } \\
\text { acts as BMP to } \\
\text { decrease runoff } \\
\text { velocity and } \\
\text { stabilize slope. }\end{array}$ \\
\hline $\begin{array}{l}\text { Figure } A-4 \text {, } \\
\text { Sheet } 3\end{array}$ & $\mathbf{F}$ & 6 & $\begin{array}{l}\text { A } 33 \text { centimeter (thirteen inch) } \\
\text { diameter "closed" corrugated pipe } \\
\text { is embedded in a square concrete } \\
\text { block located at the top of the } \\
\text { river bank. The end of the pipe } \\
\text { has a piece of sheet metal covering } \\
\text { the majority of the opening. It } \\
\text { has been identified as a culvert } \\
\text { draining the upland side of the } \\
\text { adjacent road. The bank below is } \\
\text { moderately sloped with natural } \\
\text { vegetation. }\end{array}$ & None identified. & $\begin{array}{l}\text { No contamination is } \\
\text { evident in this } \\
\text { area. No action is } \\
\text { required. }\end{array}$ \\
\hline
\end{tabular}


SURVEY SUMMARY FOR THE 100-H AREA

\begin{tabular}{|c|c|c|c|c|c|}
\hline $\begin{array}{l}\text { Map } \\
\text { Reference } \\
\text { No. }\end{array}$ & $\begin{array}{l}\text { General } \\
\text { Discharge } \\
\text { Location } \\
\text { to River } \\
\end{array}$ & $\begin{array}{l}\text { Potential } \\
\text { Point } \\
\text { Source } \\
\text { Conveyance } \\
\end{array}$ & Description/Current Status & $\begin{array}{l}\text { Potential } \\
\text { Pollutant } \\
\text { Sources }\end{array}$ & $\begin{array}{l}\text { Best Management } \\
\text { Practice(s) }\end{array}$ \\
\hline $\begin{array}{l}\text { Figure } A-4, \\
\text { Sheet } 3\end{array}$ & G & 7 & $\begin{array}{l}\text { Storm water runoff would flow from } \\
\text { a gravel roadway and terrace area } \\
\text { through an erosion area that } \\
\text { surrounds a concrete headwall on } \\
\text { the river bank, draining the upland } \\
\text { side of the adjacent road. The } \\
\text { erosion begins within feet of the } \\
\text { gravel roadway and has removed rock } \\
\text { and soil behind the concrete } \\
\text { headwall. Near the roadway the } \\
\text { bank is steeply sloped. Below the } \\
\text { headwall the bank is moderately } \\
\text { sloped to the river. The bank is } \\
\text { covered with natural vegetation. }\end{array}$ & Sediment. & $\begin{array}{l}\text { No contamination is } \\
\text { evident in the area. } \\
\text { No action is } \\
\text { required. }\end{array}$ \\
\hline $\begin{array}{l}\text { Figure A-4, } \\
\text { Sheet } 3\end{array}$ & $H$ & 8 & $\begin{array}{l}\text { A } 33 \text { centimeter ( } 13 \text { inch) diameter } \\
\text { "closed" corrugated pipe is } \\
\text { embedded in a square concrete block } \\
\text { located near the top of the river } \\
\text { bank. The end of the pipe has a } \\
\text { piece of sheet metal covering the } \\
\text { majority of the opening. It has } \\
\text { been identified as a culvert } \\
\text { draining the upland side of the } \\
\text { adjacent road. The bank below is } \\
\text { moderately sloped with natural } \\
\text { vegetation. }\end{array}$ & None identified. & $\begin{array}{l}\text { No contamination is } \\
\text { evident in this } \\
\text { area. No action is } \\
\text { required. }\end{array}$ \\
\hline
\end{tabular}


SURVEY SUMMARY FOR THE 100-H AREA

\begin{tabular}{|c|c|c|c|c|c|}
\hline $\begin{array}{c}\text { Map } \\
\text { Reference } \\
\text { No. }\end{array}$ & $\begin{array}{l}\text { General } \\
\text { Discharge } \\
\text { Location } \\
\text { to River } \\
\end{array}$ & $\begin{array}{c}\text { Potential } \\
\text { Point } \\
\text { Source } \\
\text { Conveyance } \\
\end{array}$ & Description/Current Status & $\begin{array}{l}\text { Potential } \\
\text { Pollutant } \\
\text { Sources }\end{array}$ & $\begin{array}{l}\text { Best Management } \\
\text { Practice(s) }\end{array}$ \\
\hline $\begin{array}{c}\text { Figure } A-4 \text {, } \\
\text { Sheet } 3\end{array}$ & I & 9 & $\begin{array}{l}\text { A } 15 \text { centimeter (six inch) diameter } \\
\text { pipe of unknown origin extends } \\
\text { horizontally out of the river bank. } \\
\text { The discharge point is } \\
\text { approximately } 3 \text { meters (10 feet) } \\
\text { below the top of the bank. The } \\
\text { pipe does not appear to be } \\
\text { supported and is not covered or } \\
\text { capped. It is believed to be an } \\
\text { old storm water culvert from } \\
\text { construction days. The bank is } \\
\text { moderately sloped with natural } \\
\text { vegetation. }\end{array}$ & None identified. & $\begin{array}{l}\text { Given the inactive } \\
\text { status and no } \\
\text { process operations } \\
\text { at } 100-\mathrm{H} \text {, there } \\
\text { appears to be no } \\
\text { source that could } \\
\text { discharge from this } \\
\text { pipe. No action is } \\
\text { necessary. }\end{array}$ \\
\hline $\begin{array}{c}\text { Figure A-4, } \\
\text { Sheet } 3\end{array}$ & $\mathrm{~J}$ & 10 & $\begin{array}{l}\text { An } 46 \text { centimeter (18 inch) diameter } \\
\text { corrugated pipe of unknown origin } \\
\text { extends horizontally out of the } \\
\text { river bank. The discharge point is } \\
\text { near the top of the bank and } \\
\text { approximately } 40 \text { meters ( } 131 \text { feet) } \\
\text { from the river. The pipe does not } \\
\text { appear to be supported and is not } \\
\text { covered or capped. The upper } \\
\text { portion of the bank is moderately } \\
\text { sloped and is covered with river } \\
\text { rock and dirt. The lower portion } \\
\text { of the bank is gently sloped with } \\
\text { natural vegetation. }\end{array}$ & Sediment. & $\begin{array}{l}\text { No source of } \\
\text { contamination. No } \\
\text { action is planned. }\end{array}$ \\
\hline
\end{tabular}




\section{SURVEY SUMMARY FOR THE 100-H AREA}

\begin{tabular}{|c|c|c|c|c|c|}
\hline $\begin{array}{c}\text { Map } \\
\text { Reference } \\
\text { No. }\end{array}$ & $\begin{array}{c}\text { General } \\
\text { Discharge } \\
\text { Location } \\
\text { to River }\end{array}$ & $\begin{array}{c}\text { Potential } \\
\text { Point } \\
\text { Source } \\
\text { Conveyance }\end{array}$ & Description/Current Status & $\begin{array}{c}\text { Potential } \\
\text { Pollutant } \\
\text { Sources }\end{array}$ & $\begin{array}{c}\text { Best Management } \\
\text { Practice(s) }\end{array}$ \\
\hline $\begin{array}{c}\text { Figure A-4, } \\
\text { Sheet 4 }\end{array}$ & $\mathrm{L}$ & 13 & $\begin{array}{l}\text { An area of the river bank near } \\
\text { We11 99-42 is covered with rubble, } \\
\text { which was comprised of wood and } \\
\text { metal and what looks like tar. } \\
\text { Storm water runoff would be in } \\
\text { contact with these materials prior } \\
\text { to flowing to the river. The bank } \\
\text { is moderately steep and is covered } \\
\text { predominantly with river rock. }\end{array}$ & Metal and tar. & $\begin{array}{l}\text { No source of } \\
\text { contaminat ion. } \\
\text { action is planned. } \\
\text { ing }\end{array}$ \\
\hline
\end{tabular}


SURVEY SUMMARY FOR 100-KE AND 100-KW AREAS

\begin{tabular}{|c|c|c|c|c|c|}
\hline $\begin{array}{c}\text { Map } \\
\text { Reference } \\
\text { No. }\end{array}$ & $\begin{array}{l}\text { General } \\
\text { Discharge } \\
\text { Location } \\
\text { to River }\end{array}$ & $\begin{array}{c}\text { Potential } \\
\text { Point } \\
\text { Source } \\
\text { Conveyance }\end{array}$ & Description/Current Status & $\begin{array}{l}\text { Storm Water } \\
\text { Pollutant } \\
\text { Sources }\end{array}$ & $\begin{array}{l}\text { Best Management } \\
\text { Practice(s) }\end{array}$ \\
\hline $\begin{array}{l}\text { Figure A-5, } \\
\text { Sheet } 2\end{array}$ & A & 1 & $\begin{array}{l}\text { A } 41 \text { centimeter ( } 16 \text { inch) culvert } \\
\text { is present west of } 100-K \text { perimeter } \\
\text { access road and east of } \\
107-K E \text { access road. Outfall is } \\
\text { the floodplain just north of the } \\
\text { perimeter access road. Areas } \\
\text { potentially drained from this } \\
\text { culvert and the floodplain are in } \\
\text { radiological surface contamination } \\
\text { areas. No source of runoff other } \\
\text { than from precipitation is } \\
\text { expected. }\end{array}$ & $\begin{array}{l}\text { Radiological } \\
\text { surface } \\
\text { contamination } \\
\text { area. }\end{array}$ & $\begin{array}{l}\text { Surface } \\
\text { contamination is } \\
\text { currently being } \\
\text { removed from the } \\
\text { area potentially } \\
\text { draining from this } \\
\text { culvert. Outfall is } \\
\text { approximately } \\
320 \text { meters } \\
\text { ( } 1,050 \text { feet) from } \\
\text { the river and is not } \\
\text { a storm water } \\
\text { discharge to the } \\
\text { river. No } \\
\text { additional action is } \\
\text { planned. }\end{array}$ \\
\hline $\begin{array}{c}\text { Figure A-5, } \\
\text { Sheet } 2\end{array}$ & ' & 2 & $\begin{array}{l}\text { A } 41 \text { centimeter ( } 16 \text { inch) culvert } \\
\text { is present south of } 100-K \text { perimeter } \\
\text { access road around the } 107-K E \\
\text { retention basins. Outfall is the } \\
\text { floodplain just north of perimeter } \\
\text { access road. Areas potentially } \\
\text { drained from this culvert and the } \\
\text { floodplain are in radiological } \\
\text { surface contamination areas. No } \\
\text { source of runoff other than from } \\
\text { precipitation is expected. }\end{array}$ & $\begin{array}{l}\text { Radiological } \\
\text { surface } \\
\text { contamination } \\
\text { area. }\end{array}$ & $\begin{array}{l}\text { Surface } \\
\text { contamination is } \\
\text { currently being } \\
\text { removed. Outfall is } \\
\text { approximately } \\
200 \text { meters } \\
\text { ( } 656 \text { feet) from the } \\
\text { river and is not a } \\
\text { storm water } \\
\text { discharge to the } \\
\text { river. No } \\
\text { additional action is } \\
\text { planned. }\end{array}$ \\
\hline
\end{tabular}


SURVEY SUMMARY FOR 100-KE AND 100-KW AREAS

\begin{tabular}{|c|c|c|c|c|c|}
\hline $\begin{array}{c}\text { Map } \\
\text { Reference } \\
\text { No. }\end{array}$ & $\begin{array}{c}\text { General } \\
\text { Discharge } \\
\text { Location } \\
\text { to River } \\
\end{array}$ & $\begin{array}{c}\text { Potential } \\
\text { Point } \\
\text { Source } \\
\text { Conveyance } \\
\end{array}$ & Description/Current Status & $\begin{array}{l}\text { Storm Water } \\
\text { Pollutant } \\
\text { Sources }\end{array}$ & $\begin{array}{l}\text { Best Management } \\
\text { Practice(s) }\end{array}$ \\
\hline $\begin{array}{c}\text { Figure A-5, } \\
\text { Sheet } 2\end{array}$ & B & 3 & $\begin{array}{l}\text { An eroded trench is present } \\
\text { immediately north and east of the } \\
1908-K \text { outfall structure. This } \\
\text { erosion was due to overflow during } \\
\text { maximum water usage when the } \\
100-K \text { reactors were running. Since } \\
\text { the reactors are no longer running, } \\
\text { the overflow trench is no longer in } \\
\text { use. Posted as a Radiological } \\
\text { Contamination Area. }\end{array}$ & $\begin{array}{l}\text { Radiological } \\
\text { contamination } \\
\text { area. }\end{array}$ & $\begin{array}{l}\text { There is no } \\
\text { discharge to the } \\
\text { trench, no action is } \\
\text { necessary. }\end{array}$ \\
\hline $\begin{array}{c}\text { Figure } A-5 \\
\text { Sheet } 3\end{array}$ & $E$ & 9 & $\begin{array}{l}\text { A } 41 \text { centimeter ( } 16 \text { inch) culvert } \\
\text { is present that would drain the } \\
\text { area south of } 100-K \text { perimeter } \\
\text { access road around the } 107-K W \\
\text { retention basins. The outfall is } \\
\text { the floodplain just north of } \\
\text { perimeter access road. Areas } \\
\text { potentially drained form this } \\
\text { culvert and the floodplain are in } \\
\text { radiological surface contamination } \\
\text { areas. No source of runoff other } \\
\text { than from precipitation is } \\
\text { expected. }\end{array}$ & $\begin{array}{l}\text { Radiological } \\
\text { surface } \\
\text { contamination } \\
\text { area }\end{array}$ & $\begin{array}{l}\text { One hundred and } \\
\text { fifty meters ( } 492 \\
\text { feet) from the } \\
\text { river, no action is } \\
\text { necessary. }\end{array}$ \\
\hline $\begin{array}{l}\text { Figure } A-5 \text {, } \\
\text { Sheet } 3\end{array}$ & $\mathbf{F}$ & 10 & $\begin{array}{l}\text { A } 41 \text { centimeter ( } 16 \text { inch) culvert } \\
\text { is present that would drain the } \\
\text { area south of } 100-K \text { perimeter } \\
\text { access road just east of } 181-K W \\
\text { access road. Areas potentially } \\
\text { drained from this culvert are not } \\
\text { in radiological surface } \\
\text { contamination areas, although the } \\
\text { outfall is in a radiological } \\
\text { surface contamination area. }\end{array}$ & $\begin{array}{l}\text { Radiological } \\
\text { surface } \\
\text { contamination } \\
\text { area. }\end{array}$ & $\begin{array}{l}\text { One hundred and } \\
\text { sixty meters ( } 525 \\
\text { feet) from the } \\
\text { river, no action is } \\
\text { necessary. }\end{array}$ \\
\hline
\end{tabular}


SURVEY SUMMARY FOR 100-KE AND 100-KW AREAS

\begin{tabular}{|c|c|c|c|c|c|}
\hline $\begin{array}{l}\text { Map } \\
\text { Reference } \\
\text { No. }\end{array}$ & $\begin{array}{l}\text { General } \\
\text { Discharge } \\
\text { Location } \\
\text { to River } \\
\end{array}$ & $\begin{array}{l}\text { Potential } \\
\text { Point } \\
\text { Source } \\
\text { Conveyance }\end{array}$ & Description/Current status & $\begin{array}{l}\text { Storm Water } \\
\text { Pollutant } \\
\text { Sources }\end{array}$ & $\begin{array}{l}\text { Best Management } \\
\text { Practice(s) }\end{array}$ \\
\hline \multirow[t]{2}{*}{$\begin{array}{l}\text { Figure A-5, } \\
\text { Sheet } 3\end{array}$} & \multirow[t]{2}{*}{$F$} & 12 & $\begin{array}{l}\text { A } 1.21 \text { meter } \times 1.21 \text { meter } \times 1.83 \\
\left.\text { meter ( } 4^{\prime} \times 4^{\prime} \times 6^{\prime}\right) \text { basin is present } \\
\text { in deck of } 181-K W \text { pier with outfall } \\
\text { through } 61 \text { centimeter ( } 24 \text { inch) } \\
\text { pipe east and down to the river. } \\
\text { Asbestos-wrapped pipes on deck. } \\
\text { The basin is not permitted like its } \\
\text { 181-KE counterpart and is not } \\
\text { capped. Runoff from } 108-K W \text { pier } \\
\text { surfaces is expected to outfall } \\
\text { directly to the river. }\end{array}$ & $\begin{array}{l}\text { Asbestos-wrapped } \\
\text { pipes. }\end{array}$ & $\begin{array}{l}\text { Asbestos abatement } \\
\text { is completed at this } \\
\text { location. No source } \\
\text { of contaminant. No } \\
\text { further action is } \\
\text { planned. }\end{array}$ \\
\hline & & 13 & $\begin{array}{l}\text { A 3-inch diameter pipe with a valve } \\
\text { adjacent to } 181-K W \text { fence was } \\
\text { present on the east side. }\end{array}$ & None identified. & No action necessary. \\
\hline $\begin{array}{l}\text { Figure A-5, } \\
\text { Sheet } 3\end{array}$ & G & 11 & $\begin{array}{l}\text { A } 41 \text { centimeter (16 inch) culvert } \\
\text { is present that would drain the } \\
\text { area south of } 100-K \text { perimeter } \\
\text { access road at north west corner of } \\
100-K \text { controlled area, with outfall } \\
\text { west of } 181-\mathrm{KW} \text { access road. Areas } \\
\text { potentially drained from this } \\
\text { culvert were not in radiological } \\
\text { surface contamination areas and the } \\
\text { outfall is not in a radiological } \\
\text { contamination area. }\end{array}$ & None identified. & $\begin{array}{l}\text { One hundred and } \\
\text { twenty meters } \\
\text { ( } 394 \text { feet) from the } \\
\text { river, no source of } \\
\text { contamination. No } \\
\text { action is necessary. }\end{array}$ \\
\hline
\end{tabular}


SURVEY SUMMARY FOR 100-N AREA

\begin{tabular}{|c|c|c|c|c|c|}
\hline $\begin{array}{l}\text { Map } \\
\text { Reference } \\
\text { No. }\end{array}$ & $\begin{array}{l}\text { General } \\
\text { Discharge } \\
\text { Location } \\
\text { to River }\end{array}$ & $\begin{array}{l}\text { Potential } \\
\text { Point } \\
\text { Source } \\
\text { Conveyance }\end{array}$ & Description/Current Status & $\begin{array}{l}\text { Storm Water } \\
\text { Pollutant } \\
\text { Sources }\end{array}$ & $\begin{array}{l}\text { Best Management } \\
\text { Practice(s) }\end{array}$ \\
\hline $\begin{array}{c}\text { Figure } A-6, \\
\text { Sheet } 3 \\
!\end{array}$ & D & 8 & $\begin{array}{l}\text { Erosion point in terrace that } \\
\text { drains from the storage area to } \\
\text { local gutters then to the } \\
\text { riverbank. }\end{array}$ & Sediment. & $\begin{array}{l}\text { Will repair erosion } \\
\text { point. }\end{array}$ \\
\hline $\begin{array}{l}\text { Figure } A-6, \\
\text { Sheet } 3\end{array}$ & $\mathrm{E}$ & 9 & $\begin{array}{l}\text { Major erosion point in terrace that } \\
\text { drained to riverbank. Potential } \\
\text { drainage from adjacent waste } \\
\text { storage, non-waste storage, and } \\
\text { shipping areas via local gutters. } \\
\text { Dry well that drained this area was } \\
\text { plugged, so overflow ran to this } \\
\text { erosion point. }\end{array}$ & $\begin{array}{l}\text { Area certified } \\
\text { clean. }\end{array}$ & $\begin{array}{l}\text { Erosion area has } \\
\text { been regraded. No } \\
\text { pollutant source. } \\
\text { No further action is } \\
\text { required. }\end{array}$ \\
\hline $\begin{array}{l}\text { Figure } A-6 \text {, } \\
\text { Sheet } 3\end{array}$ & & 10 & $\begin{array}{l}\text { Erosion point in terrace that } \\
\text { drains to riverbank. }\end{array}$ & Sediments. & $\begin{array}{l}\text { Eroded area has been } \\
\text { repaired and } \\
\text { designed flow path } \\
\text { has been } \\
\text { re-established. No } \\
\text { further action is } \\
\text { required. }\end{array}$ \\
\hline $\begin{array}{l}\text { Figure A-6, } \\
\text { Sheet } 3\end{array}$ & $\mathbf{F}$ & 11 & $\begin{array}{l}\text { Five centimeter (two inch) pipe. } \\
\text { Previously used in leak detection } \\
\text { system for 1304-N tank. Status: } \\
\text { abandoned process piping. Inside } \\
\text { of } 1304-N \text { is considered a } \\
\text { radiological contamination zone. }\end{array}$ & $\begin{array}{l}\text { Radiological } \\
\text { contamination } \\
\text { zone (pipe). }\end{array}$ & $\begin{array}{l}\text { No water source. } \\
\text { Icicle resulted from } \\
\text { condensation or } \\
\text { precipitation on } \\
\text { outside of pipe. No } \\
\text { action is planned. }\end{array}$ \\
\hline $\begin{array}{l}\text { Figure } A-6 \text {, } \\
\text { Sheet } 3\end{array}$ & & 12 & $\begin{array}{l}\text { Four centimeter ( } 1 \frac{1}{2} \text { inch) pipe that } \\
\text { was previously used in leak } \\
\text { detection system for } 1304-N \text { tank. } \\
\text { Status: abandoned. Pipe was dry. } \\
\text { Inside of } 1304-N \text { is considered a } \\
\text { radiological contamination zone. }\end{array}$ & $\begin{array}{l}\text { Asbestos-wrapped } \\
\text { pipe } \\
\text { radiological } \\
\text { contamination } \\
\text { zone. }\end{array}$ & $\begin{array}{l}\text { Abandoned process } \\
\text { piping. No } \\
\text { rainwater source. } \\
\text { No action required. }\end{array}$ \\
\hline
\end{tabular}


SURVEY SUMMARY FOR 100-N AREA

\begin{tabular}{|c|c|c|c|c|c|}
\hline $\begin{array}{l}\text { Map } \\
\text { Reference } \\
\text { No. }\end{array}$ & $\begin{array}{l}\text { General } \\
\text { Discharge } \\
\text { Location } \\
\text { to River }\end{array}$ & $\begin{array}{l}\text { Potential } \\
\text { Point } \\
\text { Source } \\
\text { Conveyance } \\
\end{array}$ & Description/Current Status & $\begin{array}{l}\text { Storm Water } \\
\text { Pollutant } \\
\text { Sources }\end{array}$ & $\begin{array}{l}\text { Best Management } \\
\text { Practice(s) }\end{array}$ \\
\hline $\begin{array}{l}\text { Figure } A-6 \text {, } \\
\text { Sheet } 3\end{array}$ & $\mathrm{~F}$ & 13 & $\begin{array}{l}15 \text { centimeter (six inch) pipe. } \\
\text { Drain for 1304-N Tank. Status: } \\
\text { valve closed. Inside of 1304-N is } \\
\text { considered a radiological } \\
\text { contamination zone. Pipe was dry. }\end{array}$ & $\begin{array}{l}\text { Radiological } \\
\text { contamination } \\
\text { zone. }\end{array}$ & $\begin{array}{l}\text { Abandoned process } \\
\text { piping. No } \\
\text { rainwater source. No } \\
\text { action required. }\end{array}$ \\
\hline $\begin{array}{l}\text { Figure } A-6 \text {, } \\
\text { Sheet } 3\end{array}$ & $\mathbf{G}$ & 14 & $\begin{array}{l}\text { Flume for outfall from } 1908-N \\
\text { diversion system to river. Current } \\
\text { status: Outfall 008 has been } \\
\text { discontinued and is no longer } \\
\text { permitted under NPDES. }\end{array}$ & None identified. & $\begin{array}{l}\text { No rainwater source. } \\
\text { Outfall abandoned. } \\
\text { No action required. }\end{array}$ \\
\hline $\begin{array}{l}\text { Figure } A-6, \\
\text { Sheet } 4\end{array}$ & I & 16 & $\begin{array}{l}2.54 \text { centimeter (one inch) plastic } \\
\text { pipe. Previously used as inlet for } \\
\text { river water sampling. Current } \\
\text { status: abandoned. }\end{array}$ & None identified. & $\begin{array}{l}\text { Abandoned process } \\
\text { piping. No rainwater } \\
\text { source. No action } \\
\text { required. }\end{array}$ \\
\hline $\begin{array}{l}\text { Figure } A-6 \text {, } \\
\text { Sheet } 4\end{array}$ & & 17 & $\begin{array}{l}\text { Five centimeter (two inch) iron } \\
\text { pipe. Current status: } \\
\text { unidentified. }\end{array}$ & None identified. & $\begin{array}{l}\text { Abandoned process } \\
\text { piping. No rain } \\
\text { water source. No } \\
\text { action required. }\end{array}$ \\
\hline $\begin{array}{l}\text { Figure A-6, } \\
\text { Sheet } 4\end{array}$ & & 18 & $\begin{array}{l}1.3 \text { centimeter }(0.5 \text { inch) plastic } \\
\text { pipe. Previously used as inlet for } \\
\text { river water sampling. Current } \\
\text { status: abandoned. }\end{array}$ & None identified. & $\begin{array}{l}\text { Abandoned process } \\
\text { piping. No } \\
\text { rainwater source. } \\
\text { No action required. }\end{array}$ \\
\hline $\begin{array}{l}\text { Figure A-6, } \\
\text { Sheet } 4\end{array}$ & & 19 & $\begin{array}{l}30 \text { centimeter ( } 12 \text { inch) culvert } \\
\text { drains from south of } 181-\mathrm{N} \text { to the } \\
\text { riverbank. Current status: } \\
\text { receives drainage from terrace } \\
\text { above and potentially from } \\
\text { radiological contamination area } \\
\text { near } 1304-\mathrm{N} \text {. }\end{array}$ & $\begin{array}{l}\text { Possible } \\
\text { Radiological } \\
\text { Contamination. }\end{array}$ & $\begin{array}{l}\text { No rainwater source. } \\
\text { No action required. }\end{array}$ \\
\hline $\begin{array}{l}\text { Figure } A-6 \\
\text { Sheet } 4\end{array}$ & & 20 & $\begin{array}{l}\text { Ten centimeter (four inch) iron } \\
\text { pipe. Abandoned process piping. }\end{array}$ & None identified. & $\begin{array}{l}\text { No rainwater source. } \\
\text { No action required. }\end{array}$ \\
\hline
\end{tabular}




\section{SURVEY SUMMARY FOR 100-N AREA}

\begin{tabular}{|c|c|c|c|c|c|}
\hline $\begin{array}{l}\text { Map } \\
\text { Reference } \\
\text { No. }\end{array}$ & $\begin{array}{l}\text { General } \\
\text { Discharge } \\
\text { Location } \\
\text { to River } \\
\end{array}$ & $\begin{array}{l}\text { Potential } \\
\text { Point } \\
\text { Source } \\
\text { Conveyance } \\
\end{array}$ & Description/Current Status & $\begin{array}{l}\text { Storm Water } \\
\text { Pollutant } \\
\text { Sources }\end{array}$ & $\begin{array}{l}\text { Best Management } \\
\text { Practice(s) }\end{array}$ \\
\hline $\begin{array}{l}\text { Figure A-6, } \\
\text { Sheet } 4\end{array}$ & \multirow[t]{2}{*}{ I } & 21 & $\begin{array}{l}\text { Ten centimeter (four inch) iron } \\
\text { pipe. Abandoned process piping. }\end{array}$ & None identified. & $\begin{array}{l}\text { No rainwater source. } \\
\text { No action required. }\end{array}$ \\
\hline $\begin{array}{l}\text { Figure } A-6 \text {, } \\
\text { Sheet } 4\end{array}$ & & 22 & $\begin{array}{l}\text { Five centimeter (two inch) iron } \\
\text { pipe. Previously used for return } \\
\text { tine of sampling water received } \\
\text { from river water sampling. Current } \\
\text { status: abandoned. }\end{array}$ & None identified. & $\begin{array}{l}\text { Abandoned process } \\
\text { piping. No } \\
\text { rainwater source. } \\
\text { No action required. }\end{array}$ \\
\hline $\begin{array}{l}\text { Figure } A-6 \text {, } \\
\text { Sheet } 4\end{array}$ & \multirow[t]{3}{*}{ J } & 23 & $\begin{array}{l}30 \text { centimeter ( } 12 \text { inch) pipe with } \\
\text { screen. Status: abandoned. } \\
\text { Bel ieved to be a drainage line from } \\
181-N \text {. }\end{array}$ & None identified. & $\begin{array}{l}\text { Abandoned process } \\
\text { piping. No } \\
\text { rainwater source. } \\
\text { No action required. }\end{array}$ \\
\hline $\begin{array}{l}\text { Figure A-6, } \\
\text { Sheet } 4\end{array}$ & & 24 & $\begin{array}{l}30 \text { centimeter ( } 12 \text { inch) pipe, } \\
\text { capped. Status: abandoned. } \\
\text { Believed to be a drainage line from } \\
181-\mathrm{N} \text {. }\end{array}$ & None identified. & $\begin{array}{l}\text { Abandoned process } \\
\text { piping. No } \\
\text { rainwater source. } \\
\text { No action required. }\end{array}$ \\
\hline $\begin{array}{l}\text { Figure } A-6 \text {, } \\
\text { Sheet } 4\end{array}$ & & 25 & $\begin{array}{l}30 \text { centimeter ( } 12 \text { inch) pipe. } \\
\text { Status: abandoned. Bel ieved to be } \\
\text { a drainage line from } 181-N \text {. }\end{array}$ & None identified. & $\begin{array}{l}\text { Abandoned process } \\
\text { piping. No } \\
\text { rainwater source. } \\
\text { No action required. }\end{array}$ \\
\hline $\begin{array}{l}\text { Figure } A-6 \text {, } \\
\text { Sheet } 4\end{array}$ & K & 26 & $\begin{array}{l}6.35 \text { centimeter }\left(2 \frac{1}{2} \text { inch) pipe. }\right. \\
\text { Current status: Abandoned process } \\
\text { piping, raw water return from } \\
182-N \text {. }\end{array}$ & None identified. & $\begin{array}{l}\text { No rainwater source. } \\
\text { No action required. }\end{array}$ \\
\hline $\begin{array}{l}\text { Figure } A-6 \text {, } \\
\text { Sheet } 4 \\
\end{array}$ & $L$ & 27 & $\begin{array}{l}15 \text { centimeter (six inch) aluminum } \\
\text { pipe. Current status: Abandoned } \\
\text { process piping, 182-N water tank } \\
\text { system. }\end{array}$ & None identified. & $\begin{array}{l}\text { No rainwater source. } \\
\text { No action required. }\end{array}$ \\
\hline
\end{tabular}




\section{SURVEY SUMMARY FOR 300 AREA}

\begin{tabular}{|c|c|c|c|c|c|}
\hline $\begin{array}{c}\text { Map } \\
\text { Reference } \\
\text { No. }\end{array}$ & $\begin{array}{l}\text { General } \\
\text { Discharge } \\
\text { Location } \\
\text { to River }\end{array}$ & $\begin{array}{c}\text { Potential } \\
\text { Point } \\
\text { Source } \\
\text { Conveyance } \\
\end{array}$ & Description/Current Status & $\begin{array}{l}\text { Storm Water } \\
\text { Pollutant } \\
\text { Sources }\end{array}$ & $\begin{array}{l}\text { Best Management } \\
\text { Practice (s) }\end{array}$ \\
\hline $\begin{array}{c}\text { Figure A-7, } \\
\text { Sheet } 2\end{array}$ & A & 1 & $\begin{array}{l}\text { An underground pipe drains storm } \\
\text { water from the roadway area between } \\
\text { the north side of Building } 331-c \\
\text { and the south side of Building } 331 \\
\text { to an open trench that runs east to } \\
\text { west between Buildings } 331-0 \text { and } \\
331-E \text {. The open trench is piped to } \\
\text { a culvert passing beneath a gravel } \\
\text { roadway and the perimeter fence. } \\
\text { The discharge was approximately } 46 \\
\text { meters (I50 feet) from the river. } \\
\text { The bank was moderately sloped with } \\
\text { natural vegetation. This outfall } \\
\text { results from non-industrial } \\
\text { sources. }\end{array}$ & None identified. & No action planned. \\
\hline $\begin{array}{l}\text { Figure } A-7, \\
\text { Sheet } 2\end{array}$ & B & 2 & $\begin{array}{l}\text { Located southeast of Building } 331 \text {, } \\
\text { a } 38 \text { centimeter ( } 15 \text { inch) diameter } \\
\text { pipe in a drainage ditch allows } \\
\text { runoff from the paved parking area, } \\
\text { which has a large gravel border, to } \\
\text { drain to the river. The bank is } \\
\text { moderately sloped with natural } \\
\text { vegetation. This outfall results } \\
\text { from non-industrial sources. }\end{array}$ & None identified. & No action planned. \\
\hline
\end{tabular}




\section{SURVEY SUMMARY FOR 300 AREA}

\begin{tabular}{|c|c|c|c|c|c|}
\hline $\begin{array}{l}\text { Map } \\
\text { Reference } \\
\text { No. }\end{array}$ & $\begin{array}{l}\text { General } \\
\text { Discharge } \\
\text { Location } \\
\text { to River } \\
\end{array}$ & $\begin{array}{l}\text { Potential } \\
\text { Point } \\
\text { Source } \\
\text { Conveyance } \\
\end{array}$ & Description/Current Status & $\begin{array}{l}\text { Storm Water } \\
\text { Pollutant } \\
\text { Sources }\end{array}$ & $\begin{array}{l}\text { Best Management } \\
\text { Practice(s) }\end{array}$ \\
\hline $\begin{array}{l}\text { rigure A-7, } \\
\text { sheet } 2\end{array}$ & D & 4 & $\begin{array}{l}\text { Storm water from the paved parking } \\
\text { area located northeast of } \\
\text { Building } 331 \text { flows out a channeled } \\
\text { opening in the concrete curb and a } \\
30 \text { centimeter ( } 12 \text { inch) pipe into a } \\
\text { ditch, draining under a gravel road } \\
\text { in a } 38 \text { centimeter ( } 15 \text { inch) pipe } \\
\text { to another ditch with a } \\
30 \text { centimeter ( } 12 \text { inch) pipe } \\
\text { heading toward the river. The area } \\
\text { is gently sloped with natural } \\
\text { vegetation. This outfall results } \\
\text { from non-industrial sources. }\end{array}$ & None identified. & No action planned. \\
\hline $\begin{array}{c}\text { Figure } A-7 \text {, } \\
\text { Sheet } 3\end{array}$ & E & 5 & $\begin{array}{l}\text { New parking lot was installed in } \\
1994 \text { with grass planted between the } \\
\text { parking area and the river to } \\
\text { reduce runoff. }\end{array}$ & None identified. & $\begin{array}{l}\text { Periodic visual } \\
\text { inspections will be } \\
\text { performed to assess } \\
\text { runoff. }\end{array}$ \\
\hline $\begin{array}{c}\text { Figure } A-7 \text {, } \\
\text { Sheet } 3\end{array}$ & $\mathbf{F}$ & 6 & $\begin{array}{l}\text { A sump that received the } \\
309 \text { Process sewer discharge has } \\
\text { been abandoned in-place. Runoff } \\
\text { will not enter this sump because of } \\
\text { a raised concrete slab. When the } \\
\text { new parking lot was constructed in } \\
1994 \text {, grass was planted between the } \\
\text { parking lot and the river to reduce } \\
\text { runoff. }\end{array}$ & None identified. & No action planned. \\
\hline
\end{tabular}


SURVEY SUMMARY FOR 300 AREA

\begin{tabular}{|c|c|c|c|c|c|}
\hline $\begin{array}{l}\text { Map } \\
\text { Reference } \\
\text { No. }\end{array}$ & $\begin{array}{l}\text { General } \\
\text { Discharge } \\
\text { Location } \\
\text { to River } \\
\end{array}$ & $\begin{array}{l}\text { Potential } \\
\text { Point } \\
\text { Source } \\
\text { Conveyance } \\
\end{array}$ & Description/Current Status & $\begin{array}{l}\text { Storm Water } \\
\text { Pollutant } \\
\text { Sources }\end{array}$ & $\begin{array}{l}\text { Best Management } \\
\text { Practice(s) }\end{array}$ \\
\hline $\begin{array}{c}\text { Figure } A-7 \\
\text { Sheet } 3\end{array}$ & G & 7 & $\begin{array}{l}\text { Storm water runoff would flow from } \\
\text { an area at the eastern end of } \\
\text { Locust Street over a dirt road that } \\
\text { slopes gently towards the river. } \\
\text { The road provides access to the } \\
\text { river and the } 312 \text { Intake structure. } \\
\text { Construction is taking place at the } \\
\text { eastern end of Locust Street, } \\
\text { increasing the amount of runoff } \\
\text { from the area. Lower portions of } \\
\text { the bank are gently sloped and } \\
\text { covered with natural vegetation. }\end{array}$ & None identified. & $\begin{array}{l}\text { Perform periodic } \\
\text { visual inspection to } \\
\text { assess runoff. }\end{array}$ \\
\hline $\begin{array}{c}\text { Figure A-7, } \\
\text { Sheet } 3\end{array}$ & $H$ & 8 & $\begin{array}{l}\text { A steeply sloped bank east of the } \\
315 \text { Building has significant } \\
\text { erosion. There are four distinct } \\
\text { erosion areas in which storm water } \\
\text { flows towards the river. The } \\
\text { majority of the lower portion is } \\
\text { covered with natural vegetation. A } \\
\text { retaining wall has been constructed } \\
\text { along the river in the areas where } \\
\text { there is no vegetation. }\end{array}$ & Sediments. & $\begin{array}{l}\text { Erosion is a } \\
\text { continuing problem. } \\
\text { A team has been } \\
\text { formed to evaluate } \\
\text { BMPs. }\end{array}$ \\
\hline $\begin{array}{l}\text { Figure } A-7 \text {, } \\
\text { Sheet } 3\end{array}$ & I & 9 & $\begin{array}{l}\text { Storm water runoff from the area } \\
\text { around Buildings } 3769 \text { and } 3770 \text { and } \\
\text { the adjacent roadway would flow } \\
\text { eastward through a natural ravine } \\
\text { that slopes gently toward the } \\
\text { river. Railroad ties are placed } \\
\text { end-to-end adjacent to the roadway } \\
\text { to reduce the runoff and erosion } \\
\text { from this area. The ravine is } \\
\text { covered with rock and dirt as well } \\
\text { as natural vegetation. }\end{array}$ & Sediments. & $\begin{array}{l}\text { Periodic visual } \\
\text { inspections will be } \\
\text { performed to assess } \\
\text { runoff. }\end{array}$ \\
\hline
\end{tabular}


WHC-SD-EN-EV-021, Rev. 1

APEENDIX C

FANEORD SITE LIST OF SIGNIFICANT SEIILS AND LEAKS 
Table C-1. List of Significant Spills and Leaks for the 100-B and 100-C Area.

\begin{tabular}{|c|c|c|c|c|c|c|c|c|c|c|}
\hline \multicolumn{6}{|c|}{ LIST OF SIGNIFICANT SPILLS AND LEAKS } & \multicolumn{5}{|c|}{$\begin{array}{l}\text { Worksheet \# } \\
\text { Completed by: } \\
\text { Title: } \\
\text { Date: }\end{array}$} \\
\hline \multicolumn{11}{|c|}{$\begin{array}{l}\text { Directions: Record below all significant spills and significant leaks of toxic or hazardous pollutants that have occurred at the facility in } \\
\text { the three years prior to the effective date of the permit. }\end{array}$} \\
\hline \multicolumn{11}{|c|}{ Definitions: Significant spills include, but are not limited to, releases of oil or hazardous substances in excess of reportable quantities. } \\
\hline \multirow[b]{2}{*}{$\begin{array}{c}\text { Date } \\
\text { (month/day/year) }\end{array}$} & \multirow[b]{2}{*}{ Spill } & \multirow[b]{2}{*}{ Leak } & \multirow{2}{*}{$\begin{array}{c}\text { Location } \\
\text { (as indicated on site } \\
\text { map) }\end{array}$} & \multicolumn{4}{|c|}{ Description } & \multicolumn{2}{|c|}{ Response Procedure } & \multirow{2}{*}{$\begin{array}{c}\text { Preventive } \\
\text { Measures } \\
\text { Taken }\end{array}$} \\
\hline & & & & $\begin{array}{l}\text { Type of } \\
\text { Material }\end{array}$ & Quantity & $\begin{array}{l}\text { Source, If } \\
\text { Known }\end{array}$ & Reason & $\begin{array}{l}\text { Amount of } \\
\text { Material } \\
\text { Recovered }\end{array}$ & $\begin{array}{c}\text { Material No } \\
\text { Longer } \\
\text { Exposed to } \\
\text { Stom Water } \\
\text { (True/False) }\end{array}$ & \\
\hline $5 / 92$ & $\checkmark$ & & 151-B substation & \begin{tabular}{|l} 
PCB \\
contaminated \\
mineral oil
\end{tabular} & $\begin{array}{l}200-700 \\
\text { gal }\end{array}$ & & & & & \\
\hline $2 / 92$ & $\leq$ & & $100 \mathrm{~B}$ bus lot & ethylene glycol & $1 \mathrm{gal}$ & & & & & \\
\hline 7192 & $\therefore$ & & A-2 substation & ethylene glycol & I gal & & & & & \\
\hline $1 / 94$ & $\leq$ & & 190-B Building & ethylene glycol & $22 \mathrm{lbs}$ & & & & & \\
\hline & & & & & & & & & & \\
\hline & & & & & & & & & & \\
\hline & & & & & & & & & & \\
\hline & & & & & & & & & & \\
\hline & & & & & & & & & & \\
\hline & & & & & & & & & & \\
\hline & & & & & & & & & & \\
\hline & & & & & & & & & & \\
\hline & & & & & & & & & & 1 \\
\hline & & & & & & & & & & \\
\hline
\end{tabular}


100 KE AND KW AREAS

LIST OF SIGNIFICANT SPILLS AND LEAKS

Directions: Record below all significant spills and significant leaks of toxic or hazardous pollutants that have occurred at the facility in the three years prior to the effective date of the permit.

Definitions: Significant spills include, but are not limited to, releases of oil or hazardous substances in excess of reportable guantities.

$\stackrel{i}{i}$

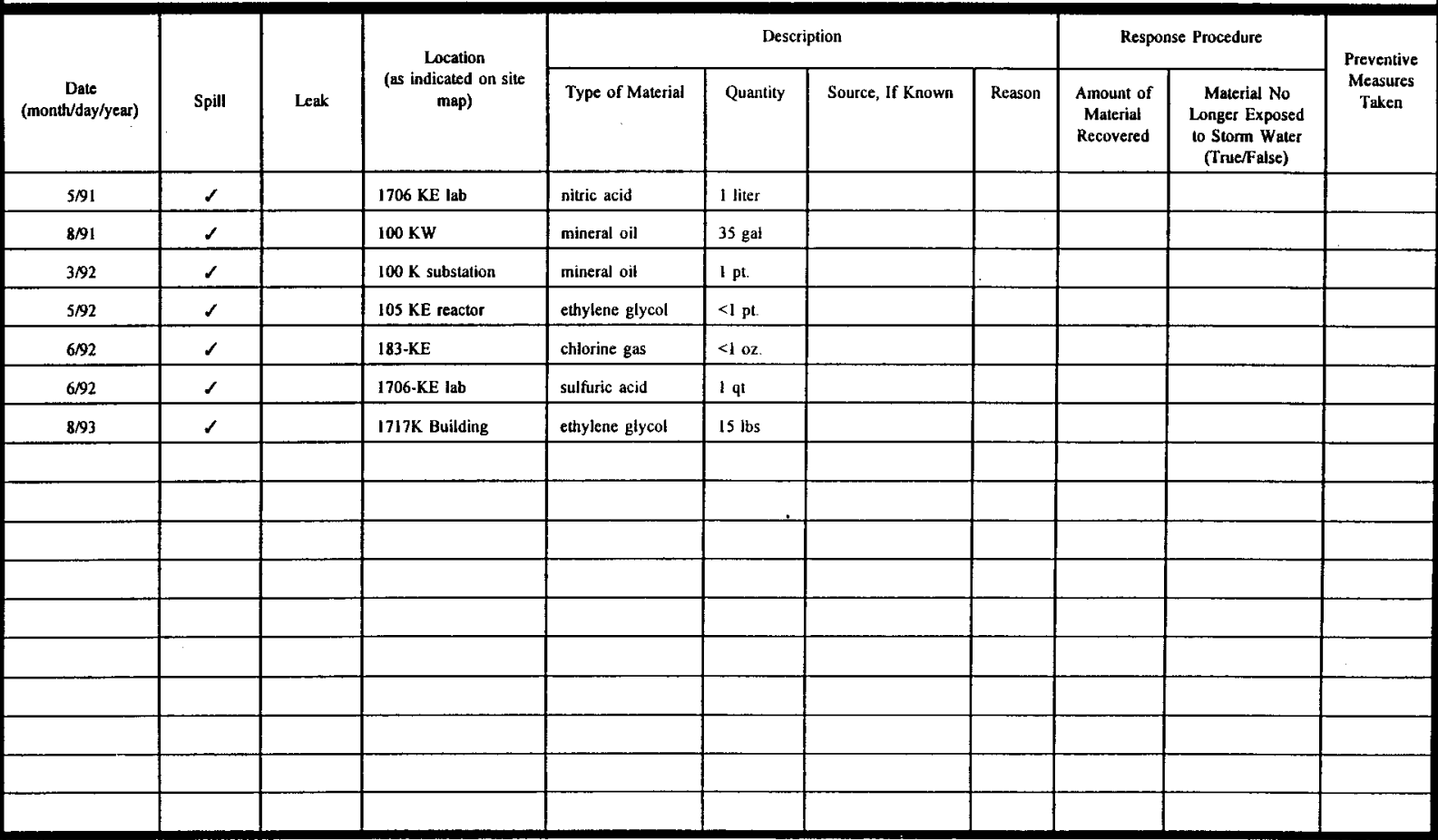

\section{Worksheet \#}

Completed by:

Title:

Date: 


\section{Worksheet \#}

Completed by:

Title:

Date:

Directions: Record below all significant spills and significant leaks of toxic or hazardous pollutants that have occurred at the facility in the three years prior to the effective date of the permit.

Definitions: Significant spilis include, but are not limited to, releases of oil or hazardous substances in excess of reportable quantities.

Date (month/day/year)

\section{\begin{tabular}{l|l|l}
\hline & Location \\
\hline
\end{tabular}}

Spill Leak

\section{(as indicated}

on site map)

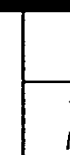

\section{Desc}

\begin{tabular}{|c|c|c|} 
& & \\
\hline $7 / 90$ & $\checkmark$ & \\
\hline
\end{tabular}

F

$12 / 90$

$6 / 91$

$\checkmark$

$7 / 91$

$.7 / 91$

$9 / 91$

\begin{tabular}{c|c|c|c}
$.10 / 91$ & $\checkmark$ & & \\
\hline $10 / 91$ & $\checkmark$ & & \\
\hline $12 / 91$ & & & 10 \\
\hline
\end{tabular}

$\checkmark$

\begin{tabular}{|c|c|}
\hline & \\
\hline & \\
\hline
\end{tabular}

$\checkmark$

\begin{tabular}{l|l|l}
\hline & & 105 \\
\hline & & 1701 \\
hous
\end{tabular}

$100 \mathrm{~N}$ service

$100 \mathrm{~N}$ service

\begin{tabular}{|l|l|l|}
\hline $\begin{array}{l}\text { station } \\
\text { bldg-N reactor }\end{array}$ & gasoline & 4 oz. \\
\hline $166-\mathrm{N}$ & diesel fuel & $1.5 \mathrm{pts}$. \\
\hline $105-\mathrm{N}$ & gasoline & 2 cues \\
\hline
\end{tabular}

\begin{tabular}{|c|c|c|c|c|}
\multicolumn{4}{c|}{ Description } & \\
\hline $\begin{array}{c}\text { Type of } \\
\text { Material }\end{array}$ & Quantity & $\begin{array}{c}\text { Source, } \\
\text { If Known }\end{array}$ & Reason & A \\
\end{tabular}

\begin{tabular}{|l|l|l|l|l|l|}
\hline Material & Qf Known & Reason & $\begin{array}{c}\text { Amount of } \\
\text { Material } \\
\text { Recovered }\end{array}$ & $\begin{array}{c}\text { Material No } \\
\text { Longer } \\
\text { Exposed to } \\
\text { Storm Water } \\
\text { (True/False) }\end{array}$ \\
\hline gasoline & & & & \\
\hline
\end{tabular}

gasoline

gasoline

105-N $\quad$ diesel fuel

\begin{tabular}{l|l}
\hline $\begin{array}{l}100-\mathrm{N} \text { badge } \\
\text { house }\end{array}$ & gasoline \\
\hline
\end{tabular}

\begin{tabular}{|l|l}
$\begin{array}{l}100-\mathrm{N} \text { badge } \\
\text { house }\end{array}$ & gasoline \\
\hline $\mathrm{MO}-910 / 100 \mathrm{~N}$ & gasoline \\
\hline $105-\mathrm{N}$ & aalon
\end{tabular}

1701-N badge

house 
Table C-3. List of Significant Spills and Leaks for the 100-N Area. (Sheet 2 of 2)

\begin{tabular}{|c|c|c|c|c|c|c|c|c|c|c|}
\hline \multicolumn{6}{|c|}{ LIST OF SIGNIFICANT SPILLS AND } & \multicolumn{5}{|c|}{$\begin{array}{l}\text { Worksheet \# } \\
\text { Completed by: } \\
\text { Title: } \\
\text { Date: }\end{array}$} \\
\hline \multicolumn{11}{|c|}{$\begin{array}{l}\text { Directions: Record below all significant spills and significant leaks of toxic or hazardous pollutants that have occurred at the facility in the three } \\
\text { years prior to the effective date of the permit. }\end{array}$} \\
\hline \multicolumn{11}{|c|}{ Definitions: Significant spills include, but are not limited to, releases of oil or hazardóus substances in excess of reportable quantities. } \\
\hline \multirow[b]{2}{*}{$\begin{array}{l}\text { Date } \\
\text { (month/day/year) }\end{array}$} & \multirow[b]{2}{*}{ Spilt } & \multirow[b]{2}{*}{ Leak. } & \multirow{2}{*}{$\begin{array}{c}\text { Location } \\
\text { (as indicated } \\
\text { on site map) }\end{array}$} & \multicolumn{4}{|c|}{ Description } & \multicolumn{2}{|c|}{ Response Procedure } & \multirow{2}{*}{$\begin{array}{c}\text { Preventive } \\
\text { Measures } \\
\text { Taken }\end{array}$} \\
\hline & & & & $\begin{array}{l}\text { Type of } \\
\text { Material }\end{array}$ & Quantity & $\begin{array}{l}\text { Source, } \\
\text { If Known }\end{array}$ & Reason & $\begin{array}{c}\text { Amount of } \\
\text { Material } \\
\text { Recovered }\end{array}$ & $\begin{array}{l}\text { Material No } \\
\text { Longer } \\
\text { Exposed to } \\
\text { Storm Water } \\
\text { (True/False) }\end{array}$ & \\
\hline $2 / 92$ & $\checkmark$ & & $1717-N$ & $\begin{array}{l}1515 \text { motor } \\
\text { oil }\end{array}$ & 1 pt. & & & & & \\
\hline $3 / 92$ & $\checkmark$ & & $105-\mathrm{N}$ & $\begin{array}{l}\text { ethylene } \\
\text { glycol }\end{array}$ & $0.5 \mathrm{gal}$. & & & . & & \\
\hline $3 / 92$ & $\checkmark$ & & $\begin{array}{l}100 \mathrm{~N} \text { fire } \\
\text { station }\end{array}$ & $\begin{array}{l}\text { ethylene } \\
\text { glycol }\end{array}$ & $<1 \mathrm{pt}$ & & & & & \\
\hline $5 / 92$ & $\checkmark$ & & $\begin{array}{l}100 \mathrm{~N} \text { parking } \\
\text { lot }\end{array}$ & $\begin{array}{l}\text { ethylene } \\
\text { glycol }\end{array}$ & 1 cue & & & & & \\
\hline $6 / 92$ & $\checkmark$ & & $\begin{array}{l}1705-N \\
\text { parking lot }\end{array}$ & $\begin{array}{l}\text { ethylene } \\
\text { glycol }\end{array}$ & $<1$ pt. & & & & & \\
\hline $7 / 92$ & $\checkmark$ & & $105-N$ & sulfuric acid & 1 qt. & & & & & \\
\hline
\end{tabular}


Table C-4. List of Significant Spilis and leaks for the 100-D and DR Areas.

\begin{tabular}{|c|c|c|c|c|c|c|c|c|c|c|}
\hline \multicolumn{6}{|c|}{ LIST OF SIGNIFICANT SPILLS AND LEAKS } & \multicolumn{5}{|c|}{$\begin{array}{l}\text { Worksheet \# } \\
\text { Completed by: SAIC/Golder } \\
\text { Title: Consultants } \\
\text { Date: } 3 / 8 / 93\end{array}$} \\
\hline \multicolumn{11}{|c|}{$\begin{array}{l}\text { Directions: Record below all significant spills and significant leaks of toxic or hazardous pollutants that have occurred at the facility in the three } \\
\text { years prior to the effective date of the permit. }\end{array}$} \\
\hline \multirow[b]{2}{*}{$\begin{array}{c}\text { Date } \\
\text { (month/day/year) }\end{array}$} & \multirow[b]{2}{*}{ Spill } & \multirow[b]{2}{*}{ Leak } & \multirow{2}{*}{$\begin{array}{l}\text { Location } \\
\text { (as indicated } \\
\text { on site map) }\end{array}$} & \multicolumn{4}{|c|}{ Description } & \multicolumn{2}{|c|}{ Response Procedure } & \multirow{2}{*}{$\begin{array}{c}\text { Preventive } \\
\text { Measures } \\
\text { Taken }\end{array}$} \\
\hline & & & & $\begin{array}{l}\text { Type of } \\
\text { Material }\end{array}$ & Quantity & $\begin{array}{l}\text { Source, } \\
\text { If } \\
\text { Known }\end{array}$ & Reason & $\begin{array}{l}\text { Amount of } \\
\text { Material } \\
\text { Recovered }\end{array}$ & $\begin{array}{l}\text { Material No } \\
\text { Longer } \\
\text { Exposed to } \\
\text { Storm Water } \\
\text { (True/False) }\end{array}$ & \\
\hline $4 / 91$ & $\checkmark$ & & 189-D bldg. & mercury & $0.27 \mathrm{~kg}$ & & & & & \\
\hline $5 / 91$ & $\checkmark$ & & $\begin{array}{l}\text { 100-D } \\
\text { deactivated } \\
\text { facility }\end{array}$ & mercury & minute & & & & & \\
\hline $5 / 91$ & $\checkmark$ & & $\begin{array}{l}\text { 183-D pump } \\
\text { house to } \\
\text { pond }\end{array}$ & $\begin{array}{l}\text { aluminimum } \\
\text { sulfate }\end{array}$ & $4122 \mathrm{lbs}$ & & & & & \\
\hline $6 / 91$ & $\checkmark$ & & $\begin{array}{l}189-\mathrm{D} \\
\text { substation }\end{array}$ & PCB $51 \mathrm{ppm}$ & $2-3$ oz. & & & & & \\
\hline $10 / 91$ & $\checkmark$ & & $3707-0$ & $\begin{array}{l}\text { ethylene } \\
\text { glycol }\end{array}$ & $1 \mathrm{pt}$. & & & & & \\
\hline $3 / 92$ & $\checkmark$ & & $3701-D$ & gasoline & $1 \mathrm{qt}$. & & & & & \\
\hline $11 / 94$ & $\checkmark$ & & $\begin{array}{l}1900 \\
\text { Building }\end{array}$ & $\begin{array}{l}\text { ethylene } \\
\text { glycol }\end{array}$ & $4 \mathrm{lbs}$ & $\begin{array}{l}\text { Auto } \\
\text { Anti- } \\
\text { freeze }\end{array}$ & $\begin{array}{l}\text { Car } \\
\text { overheat }\end{array}$ & $4 \mathrm{lbs}$ & $\mathrm{T}$ & Cleaned up \\
\hline & & & & & & & & & & \\
\hline & & & & & & & & & & \\
\hline & & & & & & & & & & \\
\hline & & & & & & & & & & \\
\hline
\end{tabular}




\begin{tabular}{|c|c|c|c|c|c|c|c|c|c|c|}
\hline \multicolumn{6}{|c|}{ LIST OF SIGNIFICANT SPILLS AND LEAKS } & \multicolumn{5}{|c|}{$\begin{array}{l}\text { Worksheet \# } \\
\text { Completed by: } \\
\text { Title: } \\
\text { Date: }\end{array}$} \\
\hline \multicolumn{11}{|c|}{$\begin{array}{l}\text { Directions: Record below all significant spills and significant leaks of toxic or hazardous pollutants that have occurred at the facility } \\
\text { in the three years prior to the effective date of the permit. }\end{array}$} \\
\hline \multicolumn{11}{|c|}{ Definitions: Significant spills include, but are not limited to, releases of oil or hazardous substances in excess of reportable quantities. } \\
\hline \multirow[b]{2}{*}{$\begin{array}{l}\text { Date } \\
\text { (month/day/year) }\end{array}$} & \multirow[b]{2}{*}{ Spill } & \multirow[b]{2}{*}{ Leak } & \multirow{2}{*}{$\begin{array}{c}\text { Location } \\
\text { (as indicated } \\
\text { on site map) }\end{array}$} & \multicolumn{4}{|c|}{ Description } & \multicolumn{2}{|c|}{ Response Procedure } & \multirow{2}{*}{$\begin{array}{c}\text { Preventive } \\
\text { Measures } \\
\text { Taken }\end{array}$} \\
\hline & & & & $\begin{array}{l}\text { Type of } \\
\text { Material }\end{array}$ & Quantity & $\begin{array}{c}\text { Source, If } \\
\text { Known }\end{array}$ & Reason & $\begin{array}{l}\text { Amount of } \\
\text { Material } \\
\text { Recovered }\end{array}$ & $\begin{array}{c}\text { Material No } \\
\text { Longer } \\
\text { Exposed to } \\
\text { Storm Water } \\
\text { (True/False) }\end{array}$ & \\
\hline $4 / 91$ & $d$ & & $\begin{array}{l}183-\mathrm{H} \text { solar } \\
\text { basin }\end{array}$ & $\mathrm{H} 2$ diesel & $25 \mathrm{gal}$. & & & & & \\
\hline $8 / 91$ & $\checkmark$ & & $3703-\mathrm{H}$ & gasoline & $6 \mathrm{oz}$. & & & & & \\
\hline $2 / 93$ & $\checkmark$ & & $\begin{array}{l}\text { 105-H } \\
\text { Building }\end{array}$ & $\begin{array}{l}\text { ethylene } \\
\text { glycol }\end{array}$ & $2.5 \mathrm{gal}$. & & & & & \\
\hline & & & & & & & & & & \\
\hline & & & & & & & & & & \\
\hline & & & & & & & & & & \\
\hline & & & & & & & & & & \\
\hline & & & & & & & & & & \\
\hline & & & & & & & & & & \\
\hline & & & & & & & & & & \\
\hline
\end{tabular}


Table C-6. List of Significant Spills and Leaks for the 100-F Area.

\section{0-F AREA}

\section{LIST OF SIGNIFICANT SPILLS AND LEAKS}

Directions: Record below alt significant spills and significant leaks of toxic or hazardous pollutants that have occurred at the facility in the three years prior to the effective date of the permit.

Definitions: Significant spills include, but are not limited to, releases of oil or hazardous substances in excess of reportable quantities.

\begin{tabular}{|c|c|c|c|c|c|c|c|c|c|c|}
\hline \multirow[b]{2}{*}{$\begin{array}{c}\text { Date } \\
\text { (month/day/year) }\end{array}$} & \multirow[b]{2}{*}{ Spill } & \multirow[b]{2}{*}{ Leak } & \multirow{2}{*}{$\begin{array}{l}\text { Location } \\
\text { (as indicated on } \\
\text { site map) }\end{array}$} & \multicolumn{4}{|c|}{ Description } & \multicolumn{2}{|c|}{ Response Procedure } & \multirow{2}{*}{$\begin{array}{c}\text { Preventive } \\
\text { Measures } \\
\text { Taken }\end{array}$} \\
\hline & & & & $\begin{array}{l}\text { Type of } \\
\text { Material }\end{array}$ & Quantity & $\begin{array}{l}\text { Source, if } \\
\text { Known }\end{array}$ & Reason & $\begin{array}{l}\text { Amount of } \\
\text { Material } \\
\text { Recovered }\end{array}$ & $\begin{array}{l}\text { Material No } \\
\text { Longer } \\
\text { Exposed to } \\
\text { Storm Water } \\
\text { (True/False) }\end{array}$ & \\
\hline $11 / 91$ & & $\checkmark$ & & $\begin{array}{l}\text { lead dioxide } \\
\text { balls }\end{array}$ & $1 \mathrm{lb}$. & & & & & \\
\hline & & & & & & & & & & \\
\hline & & & & & & & & & & \\
\hline & & & & & & & & & & \\
\hline & & & . & & & & & & & \\
\hline & & & & & & & & & & \\
\hline & & & & & & & & & & \\
\hline & & & & & & & & & & \\
\hline & & & & & & & & & & \\
\hline
\end{tabular}

Worksheet \#

Completed by:

Title:

Date: 


\section{AREA}

LIST OF SIGNIFICANT SPILLS AND LEAKS

Worksheet \#

Completed by:

Title:

Date:

Directions: Record below all significant spills and significant leaks of toxic or hazardous pollutants that have occurred at the facility in the three years prior to the effective date of the permit.

Cefinitions: Significant spills include, but are not limited to, releases of oil or hazardous substances in excess of reportable quantities.

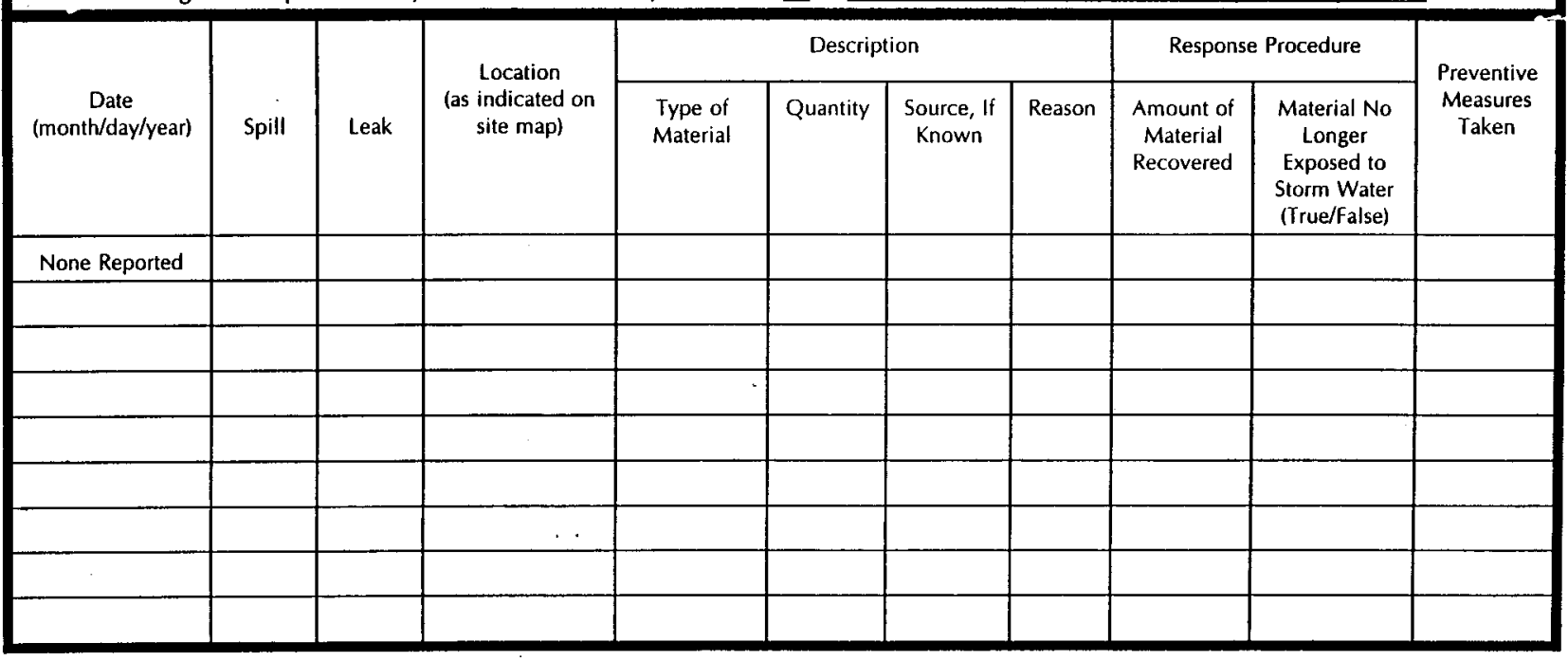


WH C -SD-EN-EV-021, Rev. 1

APPENDIX D

STATUS REPORT ON IMPLEMENTATION OF HANFORD SITE SWPPP 


\section{CORRESPONDENCE DISTRIBUTION COVERSHEET}

Auehor

J. E. Turnbaugh, 372-0863
Hadressee

J. D. Bauer, RL
Correspondence No.

9358372

SUbject: STATUS REPORT ON IMPLEMENTATION OF HANFORD SITE STORM WATER POLLUTION PREVENTION PLAN

INTERNAL DISTRIBUTION
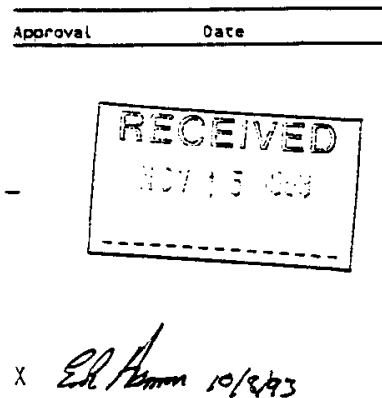

Nane

Locacion

w/at:

Correspondence Control

A3-01

$x$

President's office

B3-01

B. A. Austin

B2-35

G. D. Carpenter

H6-20

C. K. Disibio

B3-15

F. E. Erickson

P7-79

K. A. Gano

$\times 0-21$

E. R. Hamm

$54-64$

G. W. Jackson

46-21

$x<\lg \operatorname{lin}_{-2} 10 / 8 / 93$

A. 0. Krug

H6-02

D. E. Kelley

RI-48

J. R. Kelly

R3-28

R. J. Landon

H6-21

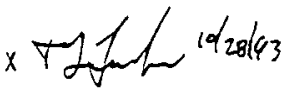

T. J. Lazarski

G7 -33

$x$

R. E. Lerch

$B 3-63$

P. J. Mackey

B3-15

H. E. McGuire

$83-63$

M. R. Morton

R2-77

$x$

R. L. Newell

E6-31

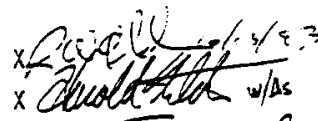

\section{3}

$10 / 26 / 93$

R. W. Oldham

H6-25

H. T. Tilden

P7-79

Ho-25

H5-27

T. J. Varljen

H6-22

B. L. Vedder

L4-96

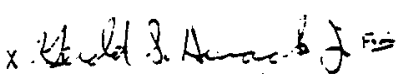

T. B. Veneziano

$\times 0-41$

D. J. Watson

B3- 15

B. D. Williamson

H6-08

EPIC

H6-25

\section{* Ofomodol vitalas}

JET/FiTe/LB 
P.0. Box 1970 Richland. WA 99352

November 10, 1993

Mr. J. O. Bauer, Program Manager

Office of Environmental Assurance,

Pormits, and Policy

U.S. Department of Energy

Richland Operations Office

Richland, Washington 99352

- Dear Mr. Bauer:

STATUS REPORT ON IMPLEMENTATION OF HANFORD SITE STORM WATER POLLUTION PREVENTION PLAN

The purpose of this letter is to document the status and progress to date of implementation of the Hanford site Stom water Pollution Prevention plan (SWPPP).

The U.S. Department of Energy, Richiand Operations office (RL) has apolied for Coverage of the Hanford Sita under the U.S. Environmental Protection Agency (EPA), Region 10 general storm water permit (WA-R-00-000F, Permit) as a means of complying with the federal storm watar rules. The Hanford Site SWPPP (WHC-SO-EN-EV-02I, ReV. 0, SWPPP) was prepared as required by April 1, 1993. The Permit also required implementation of the SwPpp by October 1, 1993.

Disposition of Potential Outfalis Identified in the Hanford Site SwPpp

The SWPpp identified 87 potential stom water outfalls to the Columbia River in the 100 and 300 Areas. A Storm Water Pollution Prevention Team (Team) was organized as required by the Permit to study the identified outfalls and determine their appropriate disposition under the storm water rules. The Tean researched the potential outfalls, identified those that could actually be outfalls and inspected them in the field to determine their disposition. Tean members representing the 100 and 300 Areas then summarized the appropriate actions that were taken on each of the outfalls. Their roports are enclosed with this letter.

Two additional potential outfalls were identified by the Team in the 100 Area. These sites are known as the 116-8-7 Outiall Structure and the 116-0-5 Outfall Structure, respectively. These additional sites will be dispositioned in Fiscal Year (FY) 1994. 
Page 2

November 10,1993

\section{Certification of Outfalls for Non-Storm Water Discharges}

The outfall disposition process was not completed in time to achieve certification that the few actual outfalls do not contain non-storm water discharges. The Permit requires non-storm water certification by Octooer 1, 1993 and further requires notification to the EPA if certification is not achieved. A letter was prepared for RL to forvard to the EPA to fulfill the permit notification requirement.

- Actions to be Accomplished in FY 1994

Work in FY 94 will focus on revising the SWPPP, certifying the storm watar outfalls that require certification and estabilishing internal procedures for periodic inspection and monitoring, if necessary.

\section{Sumary}

At this time, there appears to be only one site that can be considered a regulated storm water outrall under the Hanford site-wide general storm water permit." That outfall drains storm water from Pacific Northwest Laboratories (PNL) Buildings in the 300 Area and is designated A-1 in Table A-13 of the SWPPP. PNL has assarted that this outfall should be exempt, because their operations are not classified as "industrial" within the meaning of the storm water rules. However, the Hanford site storm water general permit is a site-wide permit and does not recognize differences between individual buildings and activities on the site with regard to storm water regulation. This issue will be resolved in FY 1994.

Should you have any questions, please contact $\mathrm{Mr}$. J. J. Luke of ny staff on $376-8629$.

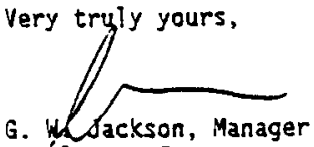

Regúlatory Support

Restoration and Remediation

ikt

Enclosures 5

RL - C. C. Haass

R. O. Puthoff ( $w / 0$ enciosure)

R. P. Saget. 
WHC-SD-EN-EV-027, Rev. I

Enclosura 1

9358372

- This page intentionally left blank. 
From: 100 Area Remedial investigation

$81310-93-029$

Phone: 375-5634 $\mathrm{H6} 6-02$

Date: September 2, 1993

Subject: 100 Area Stormwater Runoff Sites

To:

I have reviewed the 100 Area sites identified in the Hanford Site Stormwater Pollution Prevention Plan as potential pollution sources and conducted a field. visit to the sites. Seventeen of these sites can be considered as part of the 100 Area CERCLA/RCRA Past Practice. Eleven of these sites require no action because there were no sources of contamination and/or there were no pathways to the river. Three sites require a management action and three sites may require field action after evaluation of the results of a surface radiation survey. The following recomendations are made for these sites:

\section{Area}

Site A-1: No action because there is no source of contamination.

Site 8-2: Conduct a surface radiation survey to assess possibie surface contamination. If no surface contamination is found, take no action. If surface contanination is found, remove it or construct a berm to prevent surface runoff from crossing this area and reaching the river.

Site 6-3: Conduct a surface radiation survey to assess possible surface contamination. If no surface contamination is found, take no action. If surface contanination is found, remove it or construct a berm to prevent surface runoff from crossing this area and reaching the river.

Area

Site A-1: No action because there is no pathway to the river.

Site A-2: Management action should be taken to provent snow piles from accumulate at the top of the embanknent.

Site A-3: Management action should be taken to prevent snow piles from accumulating at the top of the embankment. 
J. E. Turnbaugh

$81310-93-029$

Page 2

August 2, 1993

Site A-4: Management action should be taken to prevent snow piles from accumulating at the top of the embanknent.

D Area

Site A-1: No action because there is no source of contamination.

Site 3-2: Conduct a surface radiation survey to assess possible surface contamination. If no surface contamination is found, take no action. If surface contamination is found, remove it or construct berm to prevent surface runoff from crossing this area and reaching the river.

H Area

Site B-2: No action because there is no pathway and no source of contamination.

Site 0-4: No action because there is no source of contamination.

Site E-5: No action because there is no source of contamination.

Site X-12: No action because there is no pathway and no source of contamination.

F Area

Site B-4: No action because there is no source of contamination.

Site F-9: No action because there is no source of contamination.

Site G-10: No action because there is no patiway and no source of contamination.

Site G-11: No action because there is no source of contanination.

Tables 1-5 sumarize the results of the field visit and the rationale for the recomendations.

If you have any questions or need additional information, please contact me on $376-5634$.

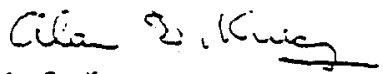

A. D. Krug

Stomwater Pollution Prevention Team

ctf 
B/C AREAS

\begin{tabular}{|c|c|c|}
\hline $\begin{array}{l}\text { GENERAL } \\
\text { LOCATION }\end{array}$ & $\begin{array}{r}\text { POINT } \\
\text { SOURCE } \\
\end{array}$ & STATUS / PROPOSED ACTION \\
\hline$A$ & 1 & $\begin{array}{l}\text { 100-8C-1 Operable Unit: The site was } \\
\text { incorrectly identified in the Swppp as "132-C- } \\
2 \text { Outfarl". It is actually the "116-C-4 } \\
\text { Outfall". There is no known surface } \\
\text { contamination in the area. Figures I \& } 2 \text {. } \\
\text { No action is proposed because there is no } \\
\text { source of contamination. }\end{array}$ \\
\hline$B$ & 2 & 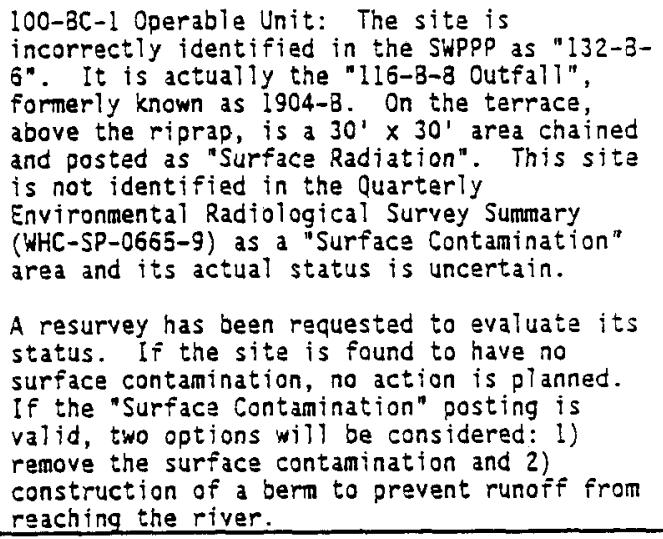 \\
\hline C & 3 & 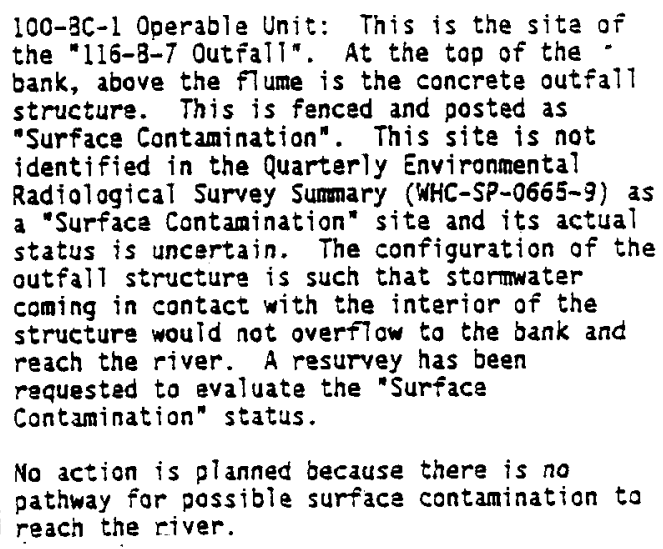 \\
\hline
\end{tabular}


O/DR AREAS

\begin{tabular}{|c|c|c|}
\hline $\begin{array}{l}\text { GENERAL } \\
\text { LOCATION } \\
\end{array}$ & $\begin{array}{r}\text { POINT } \\
\text { SOURCE } \\
\end{array}$ & STATUS / PROPOSED ACTION \\
\hline A & 1 & $\begin{array}{l}\text { 100-OR-1 Operable Unit: The site is identified } \\
\text { as the 116-DR-5 outfali structure. There is } \\
\text { no source of contamination which storm runoff } \\
\text { can carry to the river. Figure } 5 \text {. } \\
\text { No action is planned because there is no } \\
\text { source of contamination. }\end{array}$ \\
\hline 8 & 2 & $\begin{array}{l}\text { 100-0R-1 Operable Unit: This is identified as } \\
\text { the 116-0-5 Outfall, formerly called 1904-0. } \\
\text { The SWppp incorrectly identifies the concrete } \\
\text { outfall structure as being fenced and posted } \\
\text { as "Surface Contamination". The actual } \\
\text { posting is "Underground Radioactive Material". } \\
\text { There is no source of contamination which } \\
\text { storm runoff can carry to the river. Figure } \\
6 . \\
\text { No action is planned because there is no } \\
\text { source of contamination. }\end{array}$ \\
\hline
\end{tabular}


N Area

\begin{tabular}{|c|c|c|}
\hline $\begin{array}{l}\text { GENERAL } \\
\text { LOCATION }\end{array}$ & $\begin{array}{l}\text { POINT } \\
\text { SOURCE } \\
\end{array}$ & STATUS / PROPOSED ACTION \\
\hline$A$ & 1 & $\begin{array}{l}\text { 100-NR-1 Operable Unit: This site is a } \\
\text { former sump, used to intercept diesel fuel } \\
\text { from a large spill. The configuration of the } \\
\text { site is such that stonmater runoff would } \\
\text { enter the sump, rather than move from the } \\
\text { sump to the river. Figure } 3 \text {. } \\
\text { No action is planned because there is no } \\
\text { pathway to river. }\end{array}$ \\
\hline A & 2 & $\begin{array}{l}\text { 100-NR-1 Operable Unit: Erosion was caused } \\
\text { at this site by an excess of snow (from snow } \\
\text { removal actions) which was moved to the } \\
\text { terrace and allowed to melt. This was an } \\
\text { unusual happening because of the record } \\
\text { snowfall. Figure } 4 \text {. } \\
\text { No action is planned because a management } \\
\text { action has been taken to prevent the snow } \\
\text { accumulation at the top of the terrace. }\end{array}$ \\
\hline A & 3 & $\begin{array}{l}\text { 100-NR-l Operable Unit: Erosion was caused } \\
\text { at this site by an excess of snow (from snow } \\
\text { removal actions) which was moved to the } \\
\text { terrace and allawed to melt. This was an } \\
\text { unusual happening because of the record } \\
\text { snowfal1. Figure } 4 \text {. } \\
\text { No action is planned because a management } \\
\text { action has been taken to prevent the snow } \\
\text { accumulation at the top of the terraca. }\end{array}$ \\
\hline$A$ & 4 & $\begin{array}{l}\text { 100-NR-1 Operable Unit: Erosion was caused } \\
\text { at this stte by an excess of snow (from snow } \\
\text { removal actions) which was moved to the } \\
\text { terrace and allawed to melt. This was an } \\
\text { unusual happening because of the record } \\
\text { snowfalt. Figure } 4 \text {. } \\
\text { No action is olanned because a managenent } \\
\text { action has been taken to prevent the snow } \\
\text { accumulation at the too of the terrace. }\end{array}$ \\
\hline
\end{tabular}




\begin{tabular}{|c|c|c|}
\hline $\begin{array}{l}\text { GENERAL } \\
\text { LOCATION } \\
\end{array}$ & $\begin{array}{r}\text { POINT } \\
\text { SOURCE } \\
\end{array}$ & STATUS / PROPOSED ACTION \\
\hline 3 & 2 & $\begin{array}{l}\text { 100-HR-3 Operabie Unit: This site is a river } \\
\text { stage recorder with an eiectronic cable } \\
\text { encased in a pipe. The pipe noted in the } \\
\text { SWPpp is to shield the cable and does not } \\
\text { conduct stormwater runoff into the river. } \\
\text { Figure } 7 \text {. } \\
\text { No action is planned because there is no } \\
\text { pathway to the river nor is there a source of } \\
\text { contamination. }\end{array}$ \\
\hline 0 & 4 & $\begin{array}{l}\text { 100-HR-1 Operable Unit: This is the site of } \\
\text { the 116-H-5 Outfall. There is no source of } \\
\text { contamination at this site and it is not } \\
\text { posted. Figure } 8 \text {. } \\
\text { No action is planned because there is no } \\
\text { source of contamination. }\end{array}$ \\
\hline$E$ & 5 & $\begin{array}{l}\text { 100-HR-1 Operable Unit: This is the site of } \\
\text { the 116-H-5 outfall. There is no source of } \\
\text { contamination at this site and it is not } \\
\text { posted. Figure } 9 \text {. } \\
\text { No action is planned because there is no } \\
\text { source of contamination. }\end{array}$ \\
\hline$k$ & 12 & $\begin{array}{l}\text { 100-HR-3 Operable Unit: This site is a seep } \\
\text { monitoring recorder with an electronic cable } \\
\text { encased in a pipe. The pipe noted in the } \\
\text { swppo is to shield the cable and does not } \\
\text { conduct stormwater runoff into the river. } \\
\text { Figures } 10 \text { 11. } \\
\text { No action is planned because there is no } \\
\text { pathway to the river nor is there a source of } \\
\text { contamination. }\end{array}$ \\
\hline
\end{tabular}




\begin{tabular}{|c|c|c|}
\hline $\begin{array}{r}\text { GENERAL } \\
\text { LOCATION } \\
\end{array}$ & $\begin{array}{r}\text { POINT } \\
\text { SOURCE }\end{array}$ & STATUS / PROPOSED ACTION \\
\hline 8 & 4 & $\begin{array}{l}\text { 100-FR-2 Operable Unit: The concern at this } \\
\text { site was the potential for run off from the } \\
118-F-5 \text { area to contaninate the river. The } \\
\text { SwPpp incorrectly identifies the sight as } \\
\text { being posted "Surface Contamination". It is } \\
\text { actually posted as "Underground Radioactive } \\
\text { Materiai". Buried waste at this site is } \\
\text { covered by approximately } 15 \text { ' of clean } \\
\text { material. Figure } 12 \text {. } \\
\text { No action is planned because there is no } \\
\text { source of contamination. }\end{array}$ \\
\hline$F$ & 9 & $\begin{array}{l}\text { 100-FR-1 Operable Unit: This is the site of } \\
\text { the } 116-F-8 \text { dutfall. There is no source of } \\
\text { contamination at this site and it is not } \\
\text { posted. Figure } 13 \text {. } \\
\text { No action is planned because there is no } \\
\text { source of contamination. }\end{array}$ \\
\hline$G$ & 10 & $\begin{array}{l}\text { 100-FR-3 Operable Unit: This site is a river } \\
\text { stage recorder with an electronic cable } \\
\text { mounted on a concrete wall which is part of } \\
\text { the } 116-F-6 \text { Outfall. The pipe noted in the } \\
\text { Swppp is to shield the cable and does not } \\
\text { conduct stormwater runoff into the river. The } \\
\text { reference to Outfall " } X^{*} \text { should be to } 116-F-6 \text {. } \\
\text { Figures } 14,15 \$ 16 \text {. } \\
\text { No action is planned because there is no } \\
\text { pathway to the river, nor a source of } \\
\text { contanination. }\end{array}$ \\
\hline $\mathbf{G}$ & 11 & $\begin{array}{l}\text { 100-FR-1 Operable Unit: This is the site of } \\
\text { the } 116-F-5 \text { Outfall. Thers is no source of } \\
\text { contamination at this site and it is not } \\
\text { posted. Figures } 14 \text { 16. } \\
\text { No action is planned because there is no } \\
\text { source of contamination. }\end{array}$ \\
\hline
\end{tabular}


WHC-SD-EN-EV-021, Rev. I

Enclosure?

9358372

This page intentionally left blank. 
From: 100 Area Remedial Investigation

Phone: $376-5634$ H6-02

Date: September 8, 1993

Subject: Additional 100 Area Stormwater Runoff Sites

To: J. E: Turnbaugh H6-25

$\begin{array}{ll}\text { Ec: M. R. Adams } & \mathrm{H6-01} \\ \text { R. P. Henckel Pat } & H 6-02 \\ \text { M. M. Maiknimbalkar } & H 6-02 \\ \text { J. K. Patterson } & \mathrm{H6-27} \\ \text { J. H. Roberts } & \mathrm{H6-02} \\ \text { AOKK LB File } & \mathrm{H6-02} \\ \text { EPIC } & \mathrm{H6-08}\end{array}$

While reviewing the 100 Area sites identified in the Hanford Site Stormwater Pollution Prevention Plan as potential pollution sources and conducting a field visit to the sites, [ observed two additional sites which may need to be considered as potential pollution sources. These sites are known as the 116-8-7 outfall structure and the 116-0-5 outfall structure, respectively. Both concrete structures, which are uncovered, channel rain water into the river via an underground pipe system. Given the original use of the outfall structures to channel reactor process effluent water to the river, there is the likalihood that this pathway has surface radioactive contamination.

I recomend that a cover be placed over each of the structures to prevent rainwater from entering the structures. This will eliminate the pathway and the sites will no longer be of potential concern.

If you have any questions or need additional information, piease contact me on 376-5634.<smiles>[Mg][Mg][Mg]</smiles>
A. D. Krug
Stormmater pollution Prevention Team etf 
WHC-SD-EN-EV-021, Rev. 1

\section{Enclosure 3} 9358372

This page intentionally left blank. 
From: Environmental Safety

Phone: $\quad 373-3239 \times 0-41$

Date: September 13,1993

Subject: STORM WATER POLLUTION PLAN

To: J. E. Turnbaugh H6-25

$\begin{array}{ll}\text { ec: } . \text { A. Gano } & \times 0-21 \\ \text { R. J. Gimera } & \times 0-57 \\ \text { G. S. Hunacek } & \times 0-41 \\ \text { M. A. Mihaiic } & R 2-77 \\ \text { M. R. Mortan } & 22-77 \\ \text { R. A. Toher } & \times 0-41 \\ \text { DUW } F i l e / L 8 & \end{array}$

A Storm Water Pollution Plan (Plan) has been prepared for the Hanford Site. In this Plan $N$ Reactor had twenty-seven identified potential storm water discharges that could reach the Columbia River. Corrective actions identified in the Plan were to either eliminate the source or provide monitoring for these remaining sources.

By giant walk-downs, data searches and data confirmation all twenty-seven discharges identified in the Plan wers determined not to be discharging to the river. Some point source from piges were identified as non-operational and ground water run-off was identified as not capable of reaching the river.

This information is presented in the attached Storm Hater Pollution Plan for $100 \mathrm{~N}$ Reactor Plant.

Should you have any questions please contact myself or $G$. 5 . Hunacek of my staff on 373-1673.

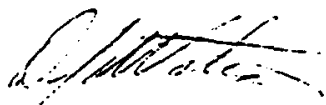

0. Jatson, Manager

Environmentai Safety

sky

Attachment

\section{BEST NWMABLE GOPY}




\title{
Storm Water Pollution
}

\author{
Prevention Plan
}

\section{For $100 \mathrm{~N}$ Reactor Plant}

Prepared by:

R. A. Toner

APPRQVED:
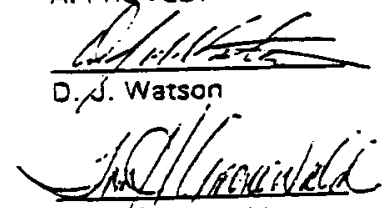

T. H. Gronewale

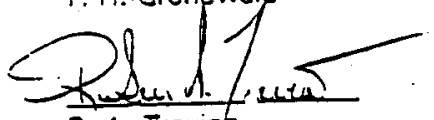

R. A. Trevirn 


\author{
EXPLANATORY NOTES \\ for \\ REMEDIAL ACTIONS \\ FOR POTENTIAL STORMWATER \\ POLLUTION POINTS \\ at \\ IOO-N REACTOR PLANT
}

These notes present the extent and the results of the investigations to deternine whether the potential drainage points at 100-N Reactor Plant

- identified in the "Hanford Site Stormwater Pollution Prevention Plan" wHC-SOEN-EV-02I. Revision I, actualiy introduce poliutants to the Columbia River. Many of these points were initially included based on initial obserytions with little follow-up investigation. Cognizant engineering and operating personnel were assigned to examine each point and to determine whether a stormwater poliution point exists and to define what corrective action would be necessary to eliminate the pollution source.

\title{
Investiaation
}

The investigations involved three activities:

1. Walkdowns

six walkdowns were conducted. The first two were to familiarize the participants with the physical locations of the "General Discharge Points". Two involved the tracing of pipes to their origin to determine their use and the operational status of the system involved. The last two examined erosion points with emohasis on those where the plan indicated potential radiological contamination.

\section{Data Searches}

Pertinent sheets of Drawing H-1-45007. Composite Underground Lines, 83 sheets, particularly sheets $9,10,16,17,30.31,43,44$, 51,58 , and 64 which cover the areas described in the Plan, were used identify the piping outfalls.

Radiation Surrey Reports Nos. 12864 and 151463 which fuliy describe the areas which were of concern in the Plan.

Contamination Control Improvement Project Database Upgrade Report for the first quarter of 1993, document number (3365093-REE-006\} dated Marei 4,1993 which documents the location and dose rate for all outdoor contaminated areas at $\mathrm{N}-\mathrm{P}$ lant.

3. Data Confimation

Meetings with System Engineers and Operations Managers wera heit to confirm the configuration and operating status of related piping 
systems. In addition, meetings were heid with Heaith Physics

personnel who provided the required interpretation of their surveys and Waste Management personnel who confimed the status of radiological waste remaining at the areas.

\section{Results}

The investigations provided favorable findings associated with the plant in three areas of concern which might have allowed pollutant laden storin water runoff into the Columbia River. These are:

i. Outdoor Radiological Contamination

The surface contamination arad (SCA) at the south end of the perimeter fence is not contaminated with windblown radioactive material. The area was posted because of deer and rabbit droppings which bio-degrade. The residual material is adsorbed into the ground and stabilized. This finding is further verified in that radiological naterial was not found on the river road below the bank.

The SCA near the 1304-it Energency Dump Tank is also stabilized radioactive material. The down slope erosion area immediately west of the SCR is completely free of contamination.

\section{Bank Erosion}

The erosion points alang the property protection perimeter security fence require repair al though the storn runofi causing the erosion contains no pollutants. Further the runofi is trapped in a depression east of road and has no pathway to the river.

However, a request to Facility Management will be made to repair and maintain site contours to eliminate uncontrolled runoff.

\section{Piping Outfalls}

All piping outfalls projecting for the river banks have been identified either by inspection or reference to the underground utilities drawings. None are stom drains. All are process piping which are now abandoned and present no potential source of ground or stoni water contamination.

One pipe identified as figure $A-3$, Sheet 4 has not been located anywhere around the 182-N Guilding or the adjacent 1900-N Tank Farm. AlT of $N-P l a n t$ water systems pipes are either steel of cast iron. However, since the 1900-i Tank Farn has been completely drained, no water source exists and there is no surface contamination in that area, the nissing pipe can be discounted as a stormater pollution source.

The piping relating to the 1304-ik Energency Dump Tank presents no stormwater pollution hazard. All of the piping is valved off and the tank itself nas been drained. 
WHC-SD-EN-EV-021, ReV. I

\section{RECOMMENDATIONS}

It is recommended the 100-N portion of the Stormwater Pollution Prevention Plan should state that no pollution source exist and that the facility is being deactivated for eventual demolition. 
Table A-5. Summary of the 100-N Area. (Sheet 1 of 5)

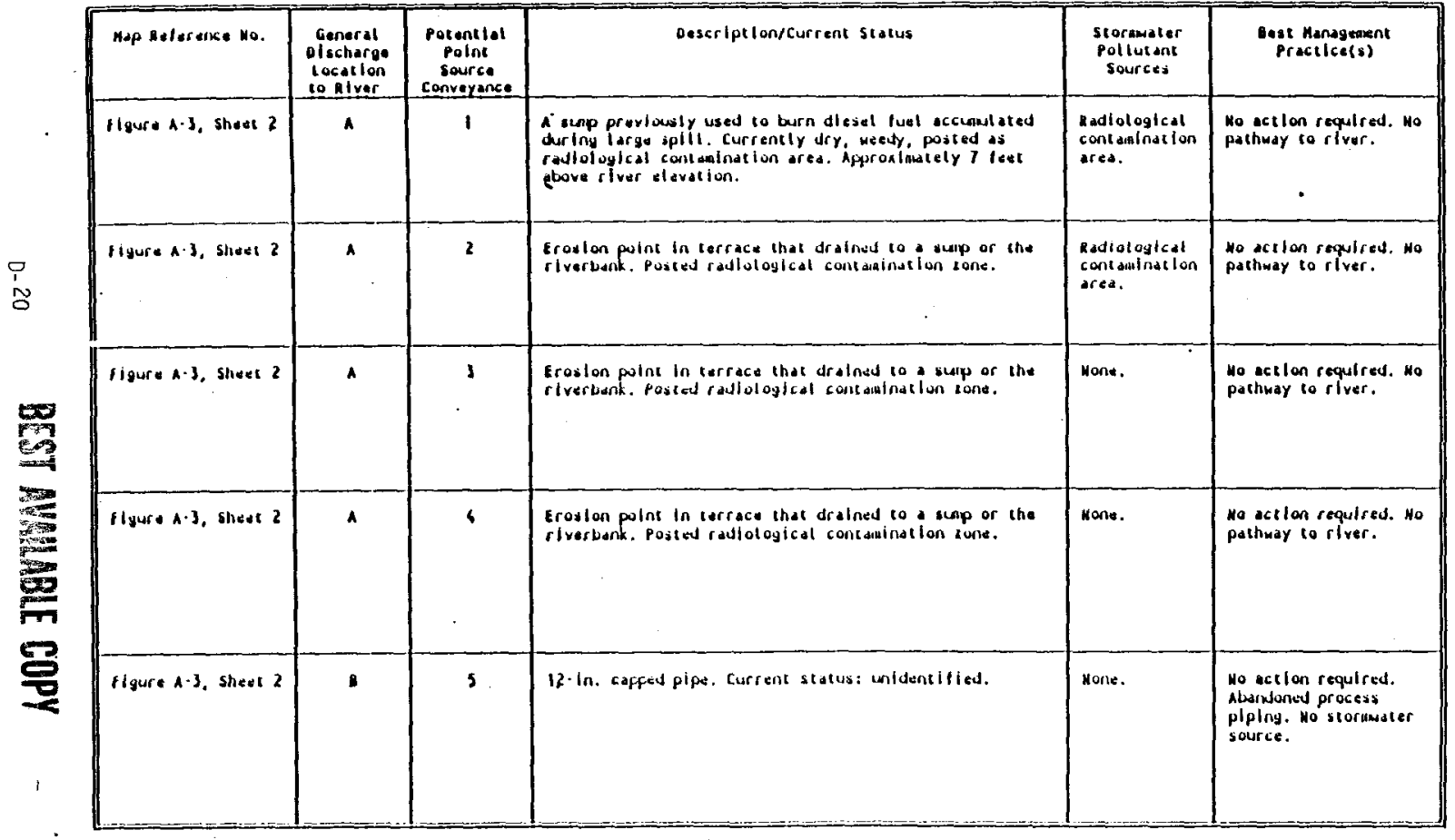




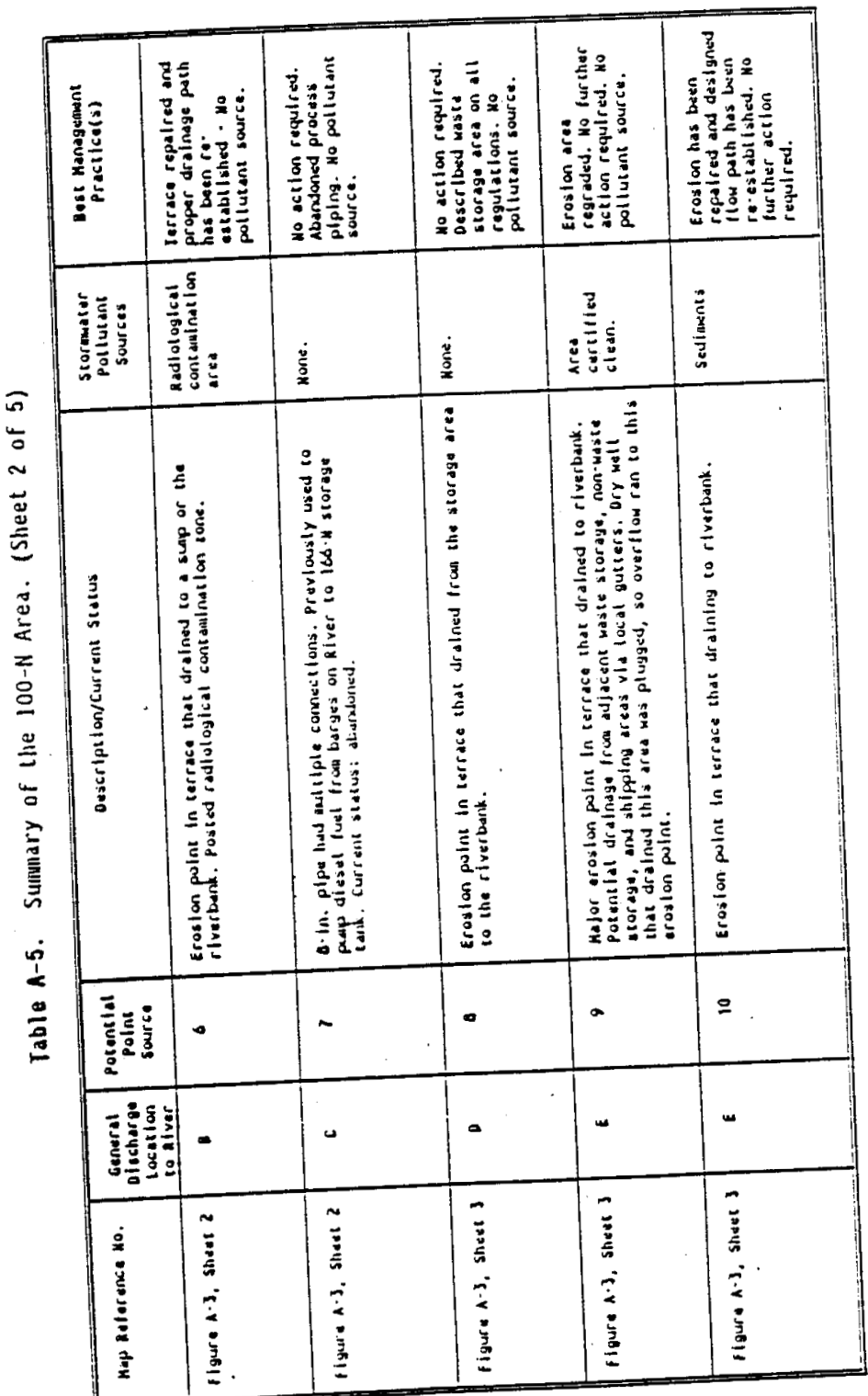




\begin{tabular}{|c|c|c|c|c|c|}
\hline 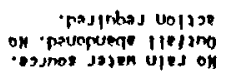 & - Dwon & 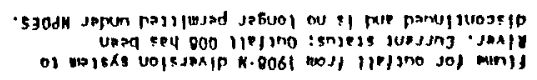 & 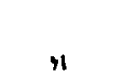 & o & 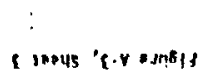 \\
\hline 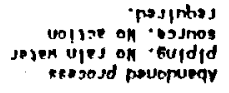 & 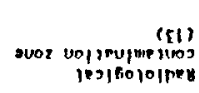 & 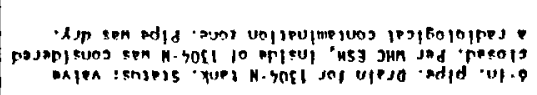 & $\$ 1$ & 1 & 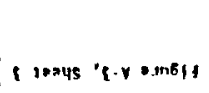 \\
\hline 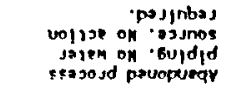 & 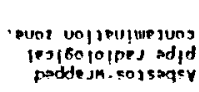 & 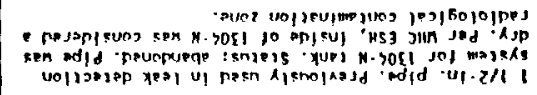 & 21 & 1 & 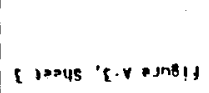 \\
\hline 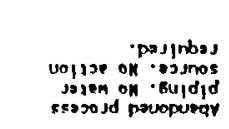 & 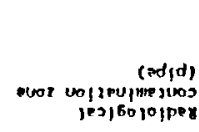 & 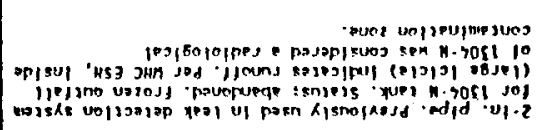 & 11 & . & 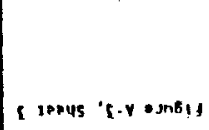 \\
\hline 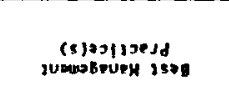 & $\begin{array}{l}\text { sas mos zue inllod } \\
\text { solemesois }\end{array}$ & 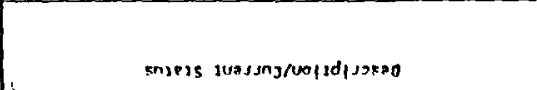 & 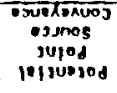 & 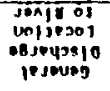 & ok osusenden den \\
\hline
\end{tabular}

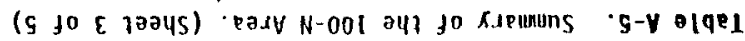


Table A-5. Summary of the 100-N Area. (Sheet 4 of 5)

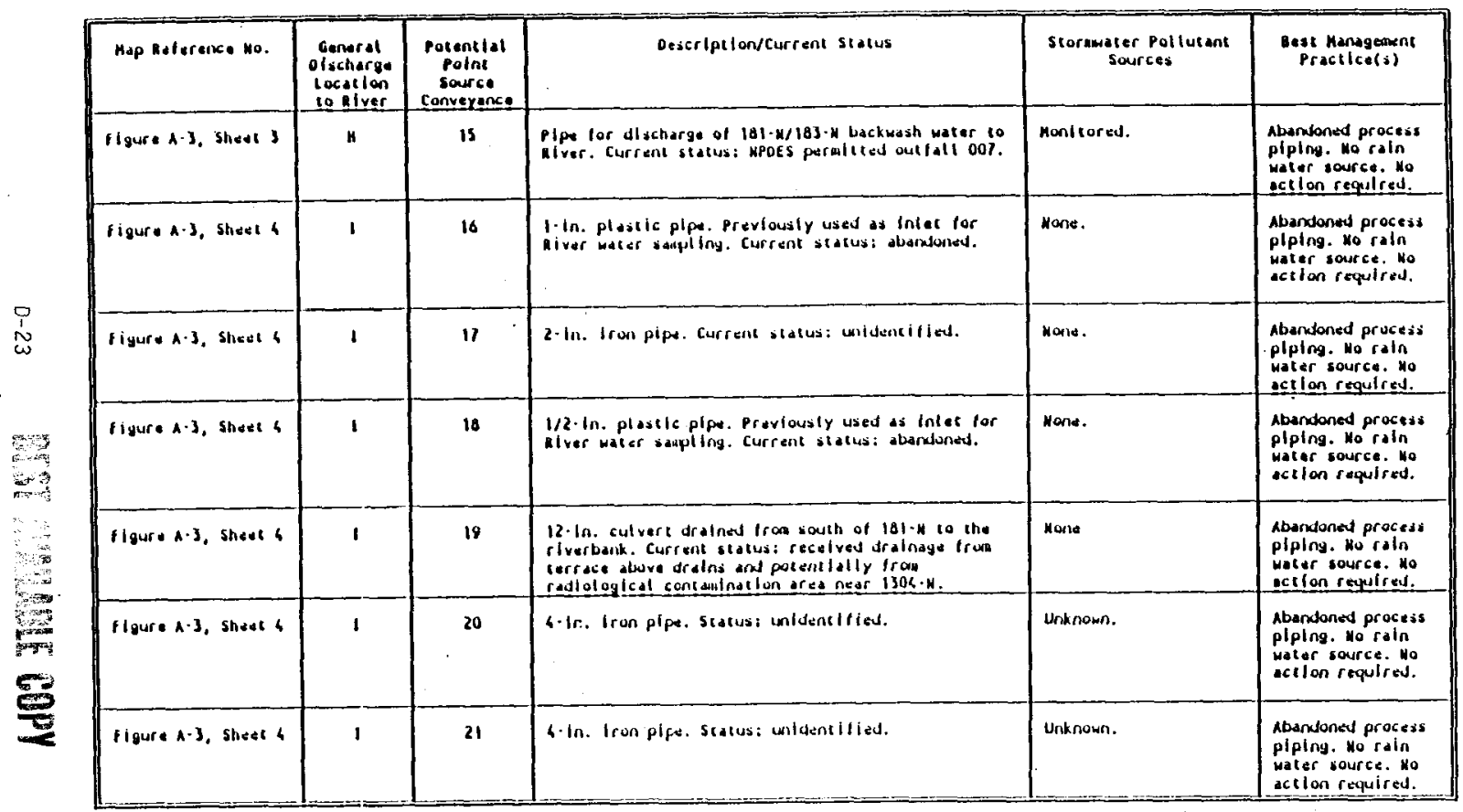


Table A-5. Sunmary of the 100-N Area. (Sheet 5 of 5)

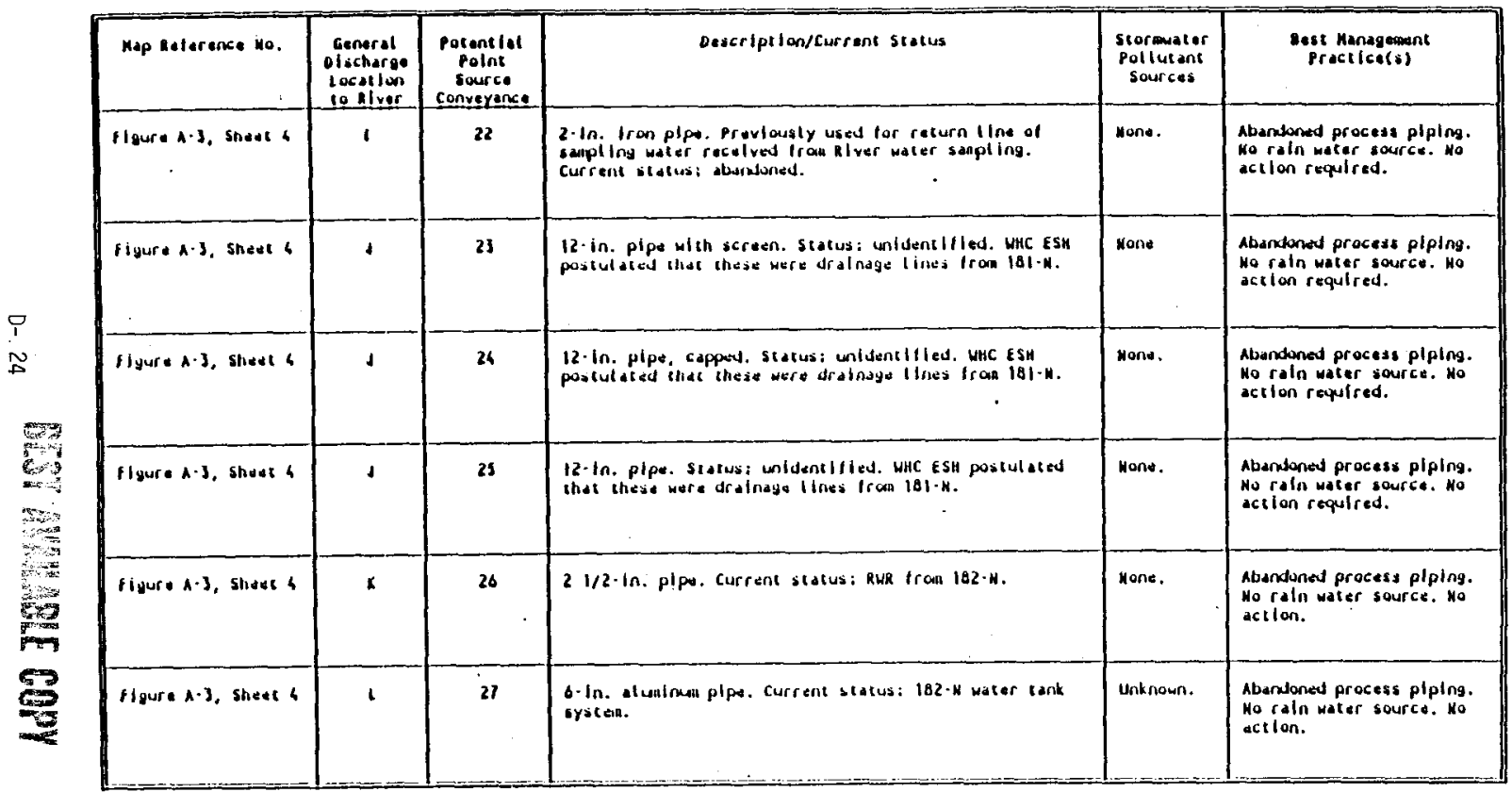


WH C-SD-EN-EV-021, Rev. 1

Enclosure 4

9358372

This page intentionally left blank.

D- 25 
DISPOSITION OF OTHER 100 AREA POTENTIAL STORMWATER OISCHARGE OUTFALLS

\section{8/C AREAS}

\begin{tabular}{|c|c|c|}
\hline $\begin{array}{c}\text { GENERAL } \\
\text { LOCATION }\end{array}$ & $\begin{array}{c}\text { POINT } \\
\text { SOURCE }\end{array}$ & \multicolumn{1}{|c|}{ STATUS / PROPOSEO ACTION } \\
\hline 0 & 4 & $\begin{array}{l}\text { Unused process wastewater discharge--no action } \\
\text { required. }\end{array}$ \\
\hline$E$ & 5 & $\begin{array}{l}\text { Improve housekeeping--not a point source } \\
\text { Conveyance of storm water }\end{array}$ \\
\hline
\end{tabular}

\section{O/OR AREAS}

\begin{tabular}{|c|c|c|}
\hline $\begin{array}{c}\text { GENERAL } \\
\text { LOCATION }\end{array}$ & $\begin{array}{c}\text { POINT } \\
\text { SOURCE }\end{array}$ & STATUS / PROPOSED ACTION \\
\hline 6 & 3 & $\begin{array}{l}\text { Improve housekeeping -not a point source } \\
\text { conveyance of storm water }\end{array}$ \\
\hline
\end{tabular}

\section{$K$ AREAS}

\begin{tabular}{|c|c|c|}
\hline $\begin{array}{c}\text { GENERAL } \\
\text { LOCATION }\end{array}$ & $\begin{array}{c}\text { POINT } \\
\text { SOURCE }\end{array}$ & STATUS / PROPOSEO ACTION \\
\hline A & 1 & $\begin{array}{l}\text { No action, } 320 \text { meters from river, no source of } \\
\text { Contamination. }\end{array}$ \\
\hline$A$ & 2 & $\begin{array}{l}\text { No action, } 200 \text { meters from river, no source of } \\
\text { Contamination. }\end{array}$ \\
\hline$B$ & 3 & $\begin{array}{l}\text { No action, } 150 \text { meters from river, no source of } \\
\text { Contamination. }\end{array}$ \\
\hline$B$ & 4 & $\begin{array}{l}\text { No action, 150 meters from river, no source of } \\
\text { Contamination. }\end{array}$ \\
\hline$C$ & 5 & NPOES oemittad wastewater jutfall, \\
\hline$C$ & 7 & Not a stom water discharge. \\
\hline 6 & 8 & Pipe is capped at 105-KE per initial report. \\
\hline
\end{tabular}




\begin{tabular}{|c|c|c|}
\hline D & 5 & $\begin{array}{l}\text { No action, } 100 \text { meters from river, no source of } \\
\text { contamination. }\end{array}$ \\
\hline E & 9 & $\begin{array}{l}\text { No action, } 150 \text { meters from river, no source of } \\
\text { contamination. }\end{array}$ \\
\hline$F$ & 10 & $\begin{array}{l}\text { No action, } 160 \text { meters from river, no source of } \\
\text { contamination }\end{array}$ \\
\hline$F$ & 12 & $\begin{array}{l}\text { Improve housekeeping to remove possible con- } \\
\text { tamination sources. Asbestos abatement is } \\
\text { scheduled for Fy } 94 \text { in the } 100 \mathrm{KH} \text { area. }\end{array}$ \\
\hline$F$ & 13 & $\begin{array}{l}\text { The exact source of this pipe remains unknown. } \\
\text { Given the inactive status of the } 181-K E \\
\text { building (ie. no operating equipment), } \\
\text { dischage from this pipe is highly unlikely }\end{array}$ \\
\hline$F$ & 14 & Capoed at 105-XN, per the initial report. \\
\hline$G$ & 11 & $\begin{array}{l}\text { No action, } 120 \text { meters from river, no source of } \\
\text { contamination }\end{array}$ \\
\hline
\end{tabular}

H AREA

\begin{tabular}{|c|c|c|}
\hline $\begin{array}{l}\text { GENERAL } \\
\text { LOCATION } \\
\end{array}$ & $\begin{array}{r}\text { POINT } \\
\text { SOURCE } \\
\end{array}$ & STATUS / PROPOSED ACTION \\
\hline A & 1 & $\begin{array}{l}\text { Believed to be a Hanford Irrigation Oistrict } \\
\text { weir box left from the pre-Manhattan Project } \\
\text { era. No surface or process source exists } \\
\text { today. }\end{array}$ \\
\hline$c$ & 3 & $\begin{array}{l}\text { Culvert draining the upland side of the } \\
\text { adjacent road. No contarination evident in } \\
\text { the area. No action. }\end{array}$ \\
\hline$E$ & 5 & $\begin{array}{l}\text { Operable Unit 100-HR-1, no action, no } \\
\text { contamination. }\end{array}$ \\
\hline$F$ & $\sigma$ & $\begin{array}{l}\text { Culvert draining the upland side of the } \\
\text { adjacent road. No contamination evident in } \\
\text { the area. No Action. }\end{array}$ \\
\hline G & 7 & $\begin{array}{l}\text { Oraining the upland side of the adjacent road. } \\
\text { No contanination evident in the area. No } \\
\text { Action. }\end{array}$ \\
\hline$H$ & 8 & $\begin{array}{l}\text { Culvert draining the upland side of the } \\
\text { adjacent road. No contamination evident in } \\
\text { the area. No Action. }\end{array}$ \\
\hline
\end{tabular}




\begin{tabular}{|c|c|l|}
\hline$I$ & $g$ & $\begin{array}{l}\text { Believed to je an old storm water culvert from } \\
\text { construction days(?) Given the inactive } \\
\text { status and no process operations at lo0-H, } \\
\text { there appears to be no source that could } \\
\text { discharge from this pioe. }\end{array}$ \\
\hline$J$ & 10 & $\begin{array}{l}\text { No action, } 40 \text { meters from river, no source of } \\
\text { contamination. }\end{array}$ \\
\hline$K$ & 11 & EFs to investigate, well labeled "9-6-88". \\
\hline$L$ & 13 & EFS to investigate, well labeled " $99-42^{\prime \prime}$. \\
\hline
\end{tabular}

F AREA

\begin{tabular}{|c|c|c|}
\hline $\begin{array}{l}\text { GENERAL } \\
\text { LOCATION } \\
\end{array}$ & $\begin{array}{l}\text { POINT } \\
\text { SOURCE } \\
\end{array}$ & STATUS / PROPOSED ACTION \\
\hline$A$ & 1 & $\begin{array}{l}\text { No contamination is evident in the area. No } \\
\text { Action. }\end{array}$ \\
\hline 8 & 2 & $\begin{array}{l}\text { No action, } 200 \text { meters from river, no source of } \\
\text { contamination. }\end{array}$ \\
\hline 3 & 3 & $\begin{array}{l}\text { No action, } 400 \text { meters from river, no source of } \\
\text { contamination. }\end{array}$ \\
\hline B & 4 & $\begin{array}{l}\text { No action, } 400 \text { meters from river, no source of } \\
\text { contamination. Operable Unit } 100-F R-1\end{array}$ \\
\hline$c$ & 5 & $\begin{array}{l}\text { No action, } 180 \text { meters from river, no source of } \\
\text { contamination. }\end{array}$ \\
\hline$c$ & 6 & EFS to investigate, well labeled "Fj-43A" \\
\hline$\underline{0}$ & $\underline{T}$ & EFS to investigate, well labeled "F5-438" \\
\hline E & 8 & EFS to investigate, well labeled "F5-44" \\
\hline$F$ & 9 & $\begin{array}{l}\text { Operable Unit 100-FR-1, no action, no source } \\
\text { of contarination. }\end{array}$ \\
\hline G & 10 & $\begin{array}{l}\text { Operable Unit 100-FR-3, no action, river stage } \\
\text { recorder. }\end{array}$ \\
\hline G & 11 & $\begin{array}{l}\text { Operable Unit 100-FR-i, no action, no source } \\
\text { of contamination. }\end{array}$ \\
\hline$H$ & 12 & $\begin{array}{l}\text { Given the inactive status and no process } \\
\text { operations at I00-F, there appears to be no } \\
\text { source that couid discharge from this oioe. }\end{array}$ \\
\hline
\end{tabular}




\begin{tabular}{|c|c|l|}
\hline$H$ & 13 & $\begin{array}{l}\text { Given the inactive status and no process } \\
\text { operations at } 100-F \text {, there appears to be no } \\
\text { source that could discharge from this pioe. }\end{array}$ \\
\hline$I$ & 14 & $\begin{array}{l}\text { Plans in process to remove these pipes and } \\
\text { material(?). }\end{array}$ \\
\hline$J$ & 15 & $\begin{array}{l}\text { No source of contamination at this seldom-used } \\
\text { boat ramp-not a point source. }\end{array}$ \\
\hline
\end{tabular}

Notes:

TThe boat ramp and storage buildings are managed by PNL--the Stom water Poliution Preyention Team toured the site and determined that it is exciuded because there is no source of contamination present. 
-WHC-SD-EN-EV-021, Rev. 1

Enclosure 5

9358372

This page intentionally left blank. 
Maintenance Environmental and Engineering Services

372-0310

September 22, 1993

300 AREA STORM WATER POLLUTION PREVENTIVE PLAN

Jerry Jurnbaugh
CC: S. E. Dieterle
$82-34$
E. R. Hamm
$54-64$
ERH File/LB

The 300 Area outfalls and Potential Point Sourees of storm water to the Columbia River have been identified, walked down and dipositioned (see attachment). One of the outfalis (A) is identified as a storm water outfall while the others (B through J) fall within the exemptions of the Nationa? Pollutant Discharge El imination System (NPDES) industrial stormater regulations and are not contaminated with any industriaj or process pollutants.

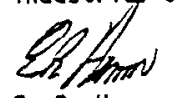

E. R. Hanm

Manager

civ 


\begin{tabular}{|c|c|c|c|c|}
\hline 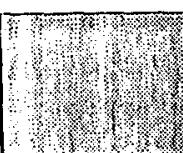 & 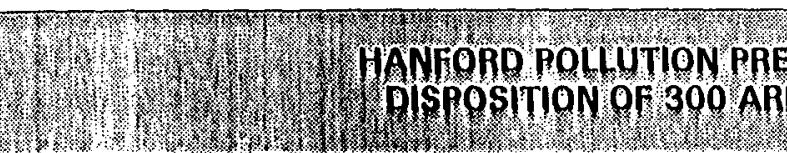 & 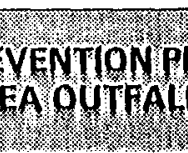 & $\mathrm{gN}^{2}$ & 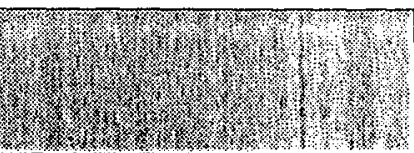 \\
\hline ofIFAL? & 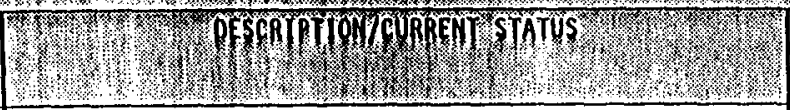 & $\begin{array}{l}\text { STORMATEP } \\
\text { POLUTAMT }\end{array}$ & $\begin{array}{l}\text { MAR } \\
\text { REFERER } \\
\text { NUMBER }\end{array}$ & 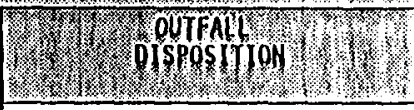 \\
\hline A & 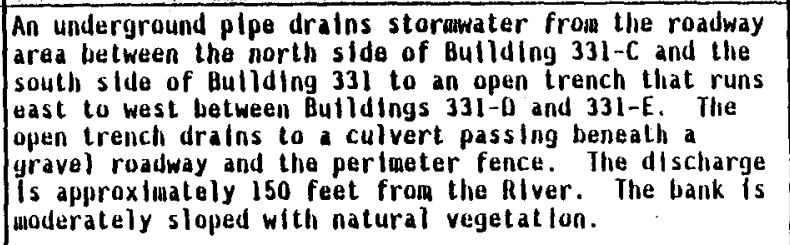 & $\begin{array}{l}\text { Sedlinent and } \\
\text { runoff from } \\
\text { storage } \\
\text { yards and } \\
\text { loading } \\
\text { docks. }\end{array}$ & $\begin{array}{l}\text { Flgure A-7 } \\
\text { Slieet } 2\end{array}$ & $\begin{array}{l}\text { llas natural berim at fence } \\
\text { line and outside fence line. } \\
\text { No erroston is evldent on } \\
\text { sloping bank. Outfall is } \\
\text { ldentiffed as a storiu- } \\
\text { water outfail under the } \\
\text { permit. }\end{array}$ \\
\hline B & $\begin{array}{l}\text { Located southeast of Bullding } 331, \text { a } 15 \text { In. diameter } \\
\text { plpe in a drainage ditch would have al lowed runoff from } \\
\text { the paved parking area, which had a large gravel } \\
\text { border, to drain to the river. The bank was moderately } \\
\text { sloped with natural vegetation. }\end{array}$ & $\begin{array}{l}\text { Paved } \\
\text { Parking lot }\end{array}$ & $\begin{array}{l}\text { Flgure A-7 } \\
\text { Sheet } 2\end{array}$ & $\begin{array}{l}\text { Outfall B is in compliance } \\
\text { with } 40 \text { CFR Chapter I } \\
(122.26) \text {, pages } 88 \text { \& } 89 \text {, see } \\
\text { attached sheet for exclusion } \\
\text { statement. }\end{array}$ \\
\hline C & 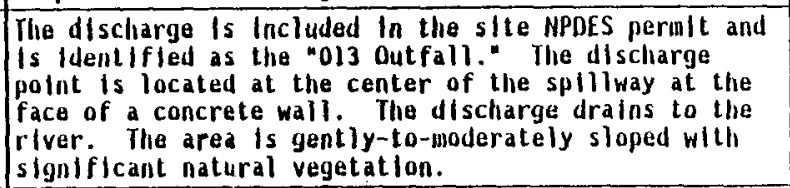 & Monitored' & $\begin{array}{l}\text { Flgure } A-7 \\
\text { Slieet } 2\end{array}$ & $\begin{array}{l}\text { Outfall is permitted by the } \\
\text { NPDES permit and no action is } \\
\text { required. }\end{array}$ \\
\hline 0 & $\begin{array}{l}\text { Storuwater from the paved parking located northeast of } \\
\text { bullding } 331 \text { flows out a channeled openting in the } \\
\text { concrete curb arid dratns onto a gravel area heading } \\
\text { toward the River. The area is gently sloped with } \\
\text { intural vegetation. }\end{array}$ & $\begin{array}{l}\text { Paved } \\
\text { parking lot }\end{array}$ & $\begin{array}{l}\text { Figure } A-T \\
\text { Stieet } 2\end{array}$ & 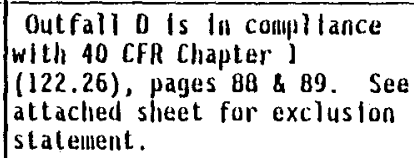 \\
\hline
\end{tabular}




\begin{tabular}{|c|c|c|c|c|}
\hline 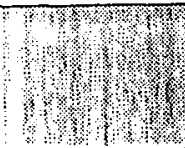 & 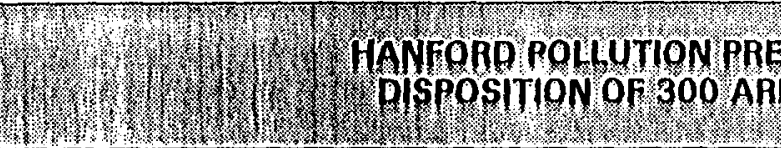 & 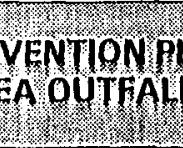 & א. & 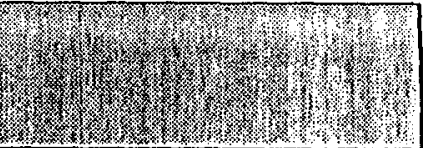 \\
\hline OUIFAl & (3) & $\begin{array}{l}\text { STOPHWATE } \\
\text { POLLUTANT } \\
\text { SOURCE }\end{array}$ & 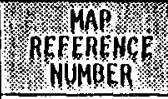 & 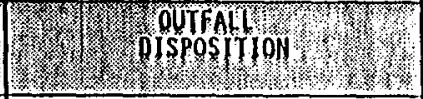 \\
\hline $\mathbf{E}$ & 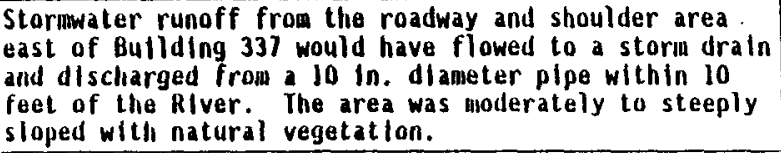 & $\begin{array}{l}\text { Paved } \\
\text { roadway a } \\
\text { graveled } \\
\text { shoulder }\end{array}$ & $\begin{array}{l}\text { Figure A-7 } \\
\text { Sheet } 3\end{array}$ & $\begin{array}{l}\text { Outfall E is in compliance } \\
\text { with } 40 \text { CFR chapter } 1 \\
\text { (122,26). pages } 88 \text { \& } 89 \text {. See } \\
\text { attached slieet for exclusion } \\
\text { statement. }\end{array}$ \\
\hline$F$ & $\begin{array}{l}\text { Stariwater runoff from the parking, roadway and } \\
\text { slioulder area east of bullding } 337 \text { would liave drained } \\
\text { to a large buried gravity sump that discharged out to a } \\
2 \text { ft. dlaaleter exfosed half-plpe to within lo feet of } \\
\text { the River. The area was moderately to steeply sloped } \\
\text { with natural vegetalion. }\end{array}$ & $\begin{array}{l}\text { Paved } \\
\text { parking } \\
\text { roadway }\end{array}$ & $\begin{array}{l}\text { Figure } A-7 \\
\text { Sheet } 3\end{array}$ & $\begin{array}{l}\text { Storimater does not draln to } \\
\text { the large gravity stilly. No } \\
\text { action required. }\end{array}$ \\
\hline G & $\begin{array}{l}\text { Storinwater runoff from an area at the eastern end of } \\
\text { Locust Streat could flow over a rock and dirt area that } \\
\text { slopes gently to the river. It appears that the area } \\
\text { aay liave been intended to provide velicle access to the } \\
\text { River. Lower partlons of the bank. were covered with } \\
\text { river rock and iatural vegetation. }\end{array}$ & $\begin{array}{l}\text { Paved road } \\
\text { and ground } \\
\text { (rock/dirt) } \\
\text { area }\end{array}$ & $\begin{array}{l}\text { F lgure A-7 } \\
\text { Shieet } 3\end{array}$ & $\begin{array}{l}\text { Outfall G is in compllance } \\
\text { with } 40 \text { CFR Chapter I } \\
(122.26) \text {, pages } 88 \text { \& } 89 \text {. See } \\
\text { attached slieet for exclusion } \\
\text { statement. }\end{array}$ \\
\hline II & $\begin{array}{l}\text { The rtver bank southeast of the } 3614-A \text { monltorling } \\
\text { Station and the pumphouse for the } 312 \text { Intake Structure } \\
\text { slowed slgniflcant erosion. Stormwater from thls area } \\
\text { as well as from the dry suinp on the west slde of the } \\
\text { roadway could flow toward the rlver. Eroslon area was } \\
\text { steeply sloped. The lower portion of the bank is } \\
\text { gently sloped toward the river and is covered with } \\
\text { natural vegetation. }\end{array}$ & $\begin{array}{l}\text { Paved road \& } \\
\text { graveled } \\
\text { shoulder }\end{array}$ & $\begin{array}{l}\text { Figure A-1 } \\
\text { Sheet } 3\end{array}$ & $\begin{array}{l}\text { Outfall II is in compllance } \\
\text { with } 40 \text { CFR Cliapter I } \\
\text { (122.26), pages } 88 \text { \& } 89 \text {. See } \\
\text { attached slieet for exclusion } \\
\text { statement. }\end{array}$ \\
\hline
\end{tabular}




\begin{tabular}{|c|c|c|c|c|}
\hline 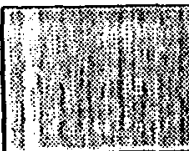 & 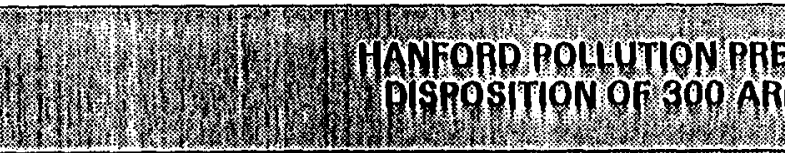 & 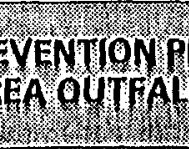 & 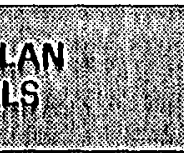 & 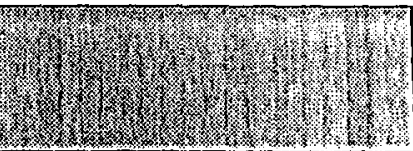 \\
\hline 3. & 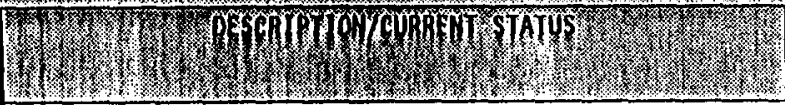 & 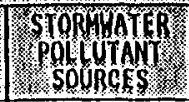 & 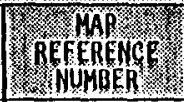 & 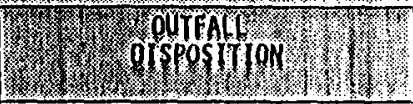 \\
\hline I & $\begin{array}{l}\text { Located east of Bulldings } 3769 \text { and } 3770 \text {, a natural } \\
\text { ravine slops gently toward the Rtver. Storimater } \\
\text { runoff from this area could flow through the ravine. } \\
\text { area is covered with rock and dirt as well as natural } \\
\text { vegetation. }\end{array}$ & $\begin{array}{l}\text { Paved road } \\
\text { and graveled } \\
\text { shoulder }\end{array}$ & $\begin{array}{l}\text { Figure } A-7 \\
\text { Sheet } 3\end{array}$ & $\begin{array}{l}\text { Rallroad tles were placed } \\
\text { to reroute the flow to avold } \\
\text { eroston. Outfall I is lin } \\
\text { compllance wtth } 40 \text { CFR } \\
\text { Chapter } 1(122.26) \text {. pages } 88 \\
\text { a9. See attached sheet for } \\
\text { excluston statement. }\end{array}$ \\
\hline$j$ & $\begin{array}{l}\text { The outfall is an } 8 \text { In. dlameter pipe that could } \\
\text { discharge to the River bank. The bank is moderately } \\
\text { sloped and is covered with natural vegetation. }\end{array}$ & Mon ltored & $\begin{array}{l}\text { Flgure } A-7 \\
\text { Sheet } 3\end{array}$ & $\begin{array}{l}\text { Unused process wastewater } \\
\text { discliarge. No action } \\
\text { required. }\end{array}$ \\
\hline
\end{tabular}

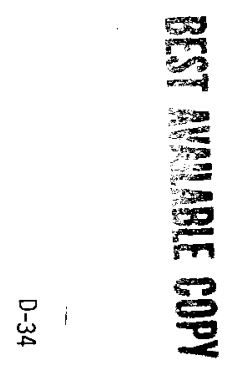




\section{ATTACHMENT}

\section{DISPOSITION OF 300 AREA OUTFALLS}

Reforence: 40 CFR Chapter 1, (122.26), Pages 88 a9, section 14 provides the following definltlan for storm water discharge assoclated with Indusirlal activity and a statement which identifies covering areas of excluston.

Definition: Storm water discharge associated Industrial activity means the discharged from any conveyance which is used for collecting and conveying storm water and which is directly related to manufacturing. processing or raw materlal storage areas at an industrial plant.

Exclusion: The term excludes areas located on plant lands separate from the plant's industrial activities such as office butldings and accompanying parking lots as long as the drainage from the excluded areas is not mixed with storm water dralned from the above described areas.

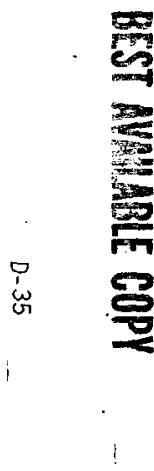


WHC-SD-EN-EV-021, Rev. T

APPENDIX E

JUSTIEICATIONS FOR OUTEALL ELIMINATION FROM THE SWPPP 
JUSTIFICATIONS FOR OUTFALL ELIMINATION FROM SWPPP

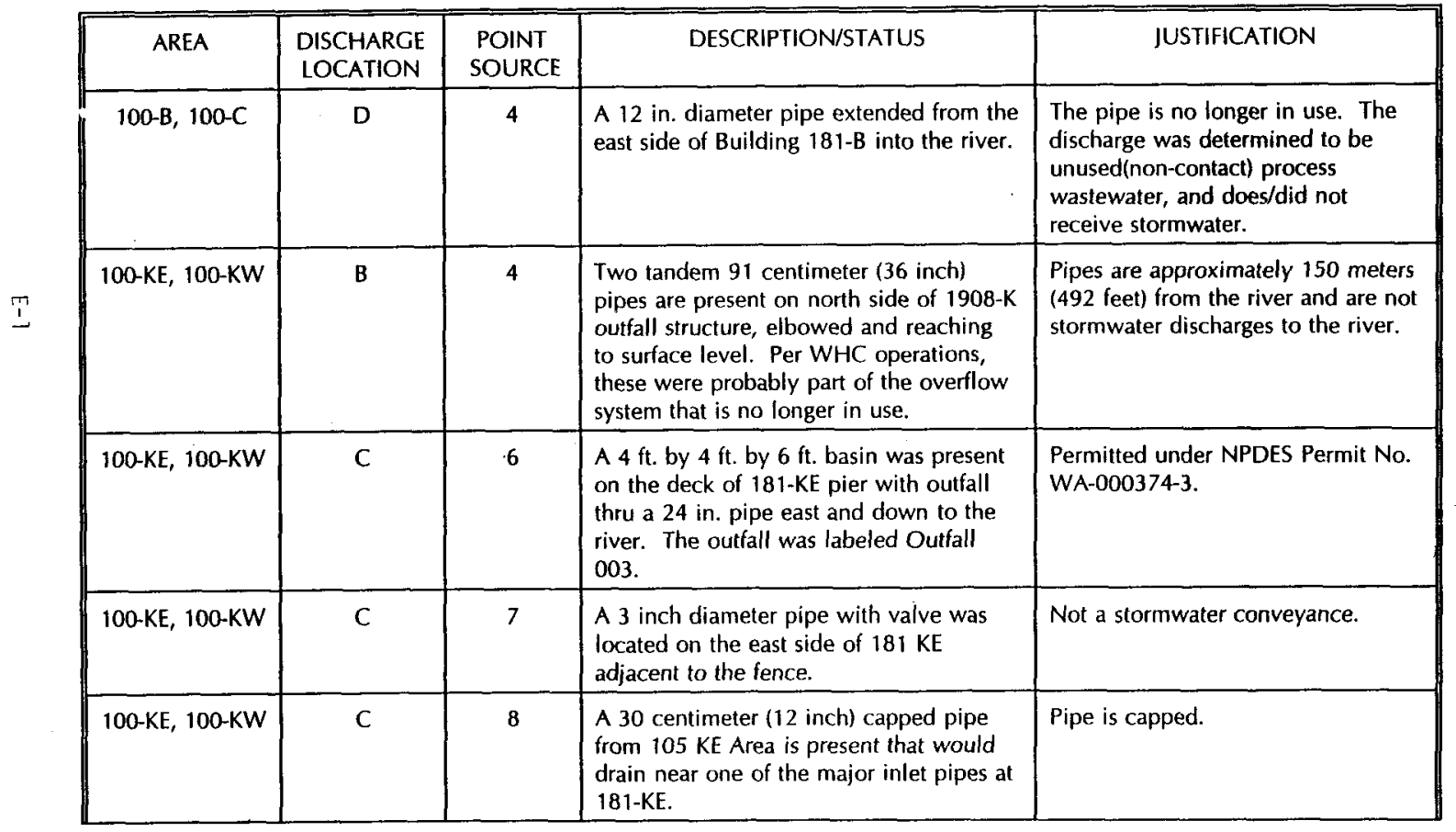




\begin{tabular}{|c|c|c|c|c|}
\hline AREA & $\begin{array}{l}\text { DISCHARGE } \\
\text { LOCATION }\end{array}$ & $\begin{array}{l}\text { POINT } \\
\text { SOURCE }\end{array}$ & DESCRIPTION/STATUS & JUSTIFICATION \\
\hline 100-KE, 100-KW & D & 5 & $\begin{array}{l}\text { A stormwater runoff area was identified } \\
\text { for the compacted soil of } 181-\mathrm{KE} \text { access } \\
\text { road. The flow would drain west down } \\
\text { the slope then north to the river. This } \\
\text { was the likely runoff point for potential } \\
\text { contaminants from drums stored at this } \\
\text { location. }\end{array}$ & $\begin{array}{l}\text { The drums have been removed. } \\
\text { There is not an erosion problem. }\end{array}$ \\
\hline 100-KE, 100-KW & $\mathrm{F}$ & 14 & $\begin{array}{l}\text { A capped } 12 \text { inch pipe from } 105-\mathrm{KE} \text { Area } \\
\text { was present that would drain near one of } \\
\text { the major inlet pipes at } 181-\mathrm{KW}\end{array}$ & Pipe is capped. \\
\hline $100-\mathrm{N}$ & A & 1 & $\begin{array}{l}\text { A sump (ditch) previously used to burn } \\
\text { diesel fuel accumulated during a large } \\
\text { spill. The site was posted as radiological } \\
\text { contamination area. }\end{array}$ & $\begin{array}{l}\text { During the proposed installation of } \\
\text { the } N \text {-springs cutoff wall this area } \\
\text { was regraded and the original } \\
\text { trench destroyed. The area now } \\
\text { slopes away from the river. No } \\
\text { cleanup was done on the area. }\end{array}$ \\
\hline $100-\mathrm{N}$ & A & $2,3,4$ & $\begin{array}{l}\text { Erosion point on terrace that drained to } \\
\text { sump }(A, 1) \text { or the riverbank. Previously } \\
\text { posted radiological contamination zone } \\
\text { (currently not posted). }\end{array}$ & $\begin{array}{l}\text { Erosion at this site was caused by } \\
\text { an excess of snow which was } \\
\text { moved to the terrace and allowed } \\
\text { to melt. This was an unusual } \\
\text { happening because of record } \\
\text { snowfall. The terrace has been } \\
\text { repaired and a proper drainage path } \\
\text { has been re-established. Action has } \\
\text { been taken to prevent snow } \\
\text { accumulation in this area. }\end{array}$ \\
\hline $100-\mathrm{N}$ & B & 5 & $\begin{array}{l}30 \text { centimeter }(12 \text {-inch) capped } \\
\text { abandoned process pipe. }\end{array}$ & $\begin{array}{l}\text { It is not a storm water source and is } \\
\text { capped. }\end{array}$ \\
\hline
\end{tabular}




\begin{tabular}{|c|c|c|c|c|}
\hline AREA & $\begin{array}{l}\text { DISCHARGE } \\
\text { LOCATION }\end{array}$ & $\begin{array}{l}\text { POINT } \\
\text { SOURCE }\end{array}$ & DESCRIPTION/STATUS & JUSTIFICATION \\
\hline $100-\mathrm{N}$ & 8 & 6 & $\begin{array}{l}\text { Erosion point in terrace that drained to a } \\
\text { sump }(A, 1) \text { or the riverbank. Posted } \\
\text { radiological contamination area. }\end{array}$ & $\begin{array}{l}\text { Terrace has been repaired and } \\
\text { proper drainage path has been re- } \\
\text { established by a berm of fill } \\
\text { material that will retain potentially } \\
\text { contaminated runoff on the terrace. }\end{array}$ \\
\hline $100-\mathrm{N}$ & c & 7 & $\begin{array}{l}20 \text { centimeter ( } 8 \text {-inch) pipe had multiple } \\
\text { connections. Intended to be used to } \\
\text { pump diesel fuel from barges on the river } \\
\text { to } 166-\mathrm{N} \text { storage tank. }\end{array}$ & $\begin{array}{l}\text { This is not a storm water source. } \\
\text { The pipe is abandoned. }\end{array}$ \\
\hline $100-N$ & $H$ & 15 & $\begin{array}{l}\text { Pipe for discharge of } 181-\mathrm{N} / 183-\mathrm{N} \\
\text { backwash water to river. }\end{array}$ & $\begin{array}{l}\text { Outfall } 007 \text { under NPDES permit } \\
\text { No. WA-000374-3. }\end{array}$ \\
\hline $100-H$ & B & 2 & $\begin{array}{l}\text { This site is a river stage recorder with an } \\
\text { electronic cable encased in the } 5 \\
\text { centimeter ( } 2 \text {-inch) diameter pipe. }\end{array}$ & $\begin{array}{l}\text { The pipe shields the cable and does } \\
\text { not conduct stormwater runoff into } \\
\text { the river. }\end{array}$ \\
\hline $100-\mathrm{H}$ & k & 11 & $\begin{array}{l}\text { A five centimeter (two inch) diameter } \\
\text { pipe extends into the river from a capped } \\
\text { monitoring well (labeled "9-6-88"). A } 91 \\
\text { centimeter (three foot) square concrete } \\
\text { pad surrounds the monitoring well at } \\
\text { ground level. The pipe is attached to the } \\
\text { concrete pad on the northwest side. }\end{array}$ & $\begin{array}{l}\text { Not a point of discharge. No } \\
\text { source of contamination. Purpose } \\
\text { of pipe will be determined/reported } \\
\text { in } 1996 \text { Hanford Storm Water } \\
\text { Comprehensive Site Compliance } \\
\text { Evaluation Report. }\end{array}$ \\
\hline $100-\mathrm{H}$ & K & 12 & $\begin{array}{l}\text { This site is a river stage recorder and/or } \\
\text { weather/monitoring station with an } \\
\text { electronic cable encased in a } 5 \\
\text { centimeter (2-inch) diameter pipe } \\
\text { entering the river. }\end{array}$ & $\begin{array}{l}\text { The pipe shields the cable and does } \\
\text { not conduct stormwater runoff into } \\
\text { the river. }\end{array}$ \\
\hline
\end{tabular}




\begin{tabular}{|c|c|c|c|c|}
\hline AREA & $\begin{array}{l}\text { DISCHARGE } \\
\text { LOCATION }\end{array}$ & $\begin{array}{l}\text { POINT } \\
\text { SOURCE }\end{array}$ & DESCRIPTION/STATUS & IUSTIFICATION \\
\hline $100-\mathrm{F}$ & A & 1 & $\begin{array}{l}\text { An open } 25 \text { centimeter (10-inch) } \\
\text { diameter pipe is present with no visible } \\
\text { outfall. The surrounding area was } \\
\text { reported to be covered with black pea } \\
\text { gravel over black tarp liner. There is a } \\
\text { small area with black plastic staked down } \\
\text { which appears to be a cross for aerial } \\
\text { surveys. No moderately built up area } \\
\text { was apparent. }\end{array}$ & $\begin{array}{l}\text { The pipe appears old. The adjacent } \\
\text { black plastic appears unrelated. } \\
\text { The area is remote and the pipe } \\
\text { does not have an outfall. Not a } \\
\text { source of stormwater. }\end{array}$ \\
\hline $100-\mathrm{F}$ & B & 2 & $\begin{array}{l}\text { An open } 15 \text { centimeter (6-inch) diameter } \\
\text { pipe extends vertically from the ground } \\
\text { and has a log jammed in its opening. } \\
\text { During the } 1995 \text { inspection the pipe } \\
\text { could not be located. }\end{array}$ & $\begin{array}{l}\text { The pipe could not be located in } \\
\text { the annual May } 1995 \text { inspection } \\
\text { nor could it be found in a } \\
\text { September } 1995 \text { follow-up } \\
\text { inspection. The pipe was reported } \\
\text { to extend vertically from the } \\
\text { ground. The area is remote and is } \\
200 \text { meters ( } 656 \text { feet) from the } \\
\text { river. No evidence of an outfall } \\
\text { exists. }\end{array}$ \\
\hline $100-\mathrm{F}$ & B & 3 & $\begin{array}{l}\text { A rusty dilapidated 55-Gal drum was } \\
\text { present. The drum was open, lying on } \\
\text { its side and appeared to contain dirt. } \\
\text { The area was covered by natural } \\
\text { vegetation and sloped gently toward the } \\
\text { river. }\end{array}$ & $\begin{array}{l}\text { The drum could not be located in } \\
\text { the } 1995 \text { inspection. The area it } \\
\text { was located in is } 60 \text { meters from a } \\
\text { dry channel and hundreds of meters } \\
\text { from the river. The drum, even if } \\
\text { located, would not be a source for } \\
\text { stormwater runoff. }\end{array}$ \\
\hline
\end{tabular}




\begin{tabular}{|c|c|c|c|c|c|}
\hline \hline AREA & $\begin{array}{l}\text { DISCHARGE } \\
\text { LOCATION }\end{array}$ & $\begin{array}{c}\text { POINT } \\
\text { SOURCE }\end{array}$ & DESCRIPTION/STATUS & JUSTIFICATION \\
\hline $100-\mathrm{F}$ & 1 & 14 & $\begin{array}{l}\text { Large concrete blocks and piping } \\
\text { material were strewn on the steep rocky } \\
\text { bank. }\end{array}$ & $\begin{array}{l}\text { Concrete blocks and piping exist, } \\
\text { but do not pose a stormwater runoff } \\
\text { problem or a source of } \\
\text { contamination. }\end{array}$ \\
\hline 300 & $\mathrm{C}$ & 3 & $\begin{array}{l}\text { This pipe discharged from the 331 } \\
\text { Building Aquaculture Facility. This } \\
\text { outfall results from non-industrial sources. }\end{array}$ & $\begin{array}{l}\text { Permitted under NPDES Permit No. } \\
\text { WA-000374-3, Outfall 013. }\end{array}$ \\
\hline 300 & $\mathrm{~J}$ & 10 & $\begin{array}{l}\text { The discharge point is a lined lagoon that } \\
\text { will receive filter backwash from the } \\
\text { water treatment plant. The oufall is a 20 } \\
\text { centimeter (8-inch) diameter pipe that } \\
\text { runs from the lagoon to the river bank. }\end{array}$ & $\begin{array}{l}\text { The pipe has been capped to } \\
\text { prevent any discharge from the } \\
\text { lagoon into the river. Scheduled to } \\
\text { be removed in FY 1996. }\end{array}$ \\
\hline
\end{tabular}


WHC-SD-EN-EV-021, ReV. 1

APPENDIX F

STORMWATER GENERAI PERMIT COVERAGE NOTICE 
U.S. Enviromental Protection Agency

Nationai Follutant Discharge El imination System (NPDES)

STORM WATER GENERAL PERMIT COVERAGE NOTICE

February 14, 1994

Dear Qperator:

Your Notice of Intent (NOI) for the facilty noted below has been processed by the U.S. Envirormental Prolection Agency. This facility is authorized to discharge storm water associated with industrial or construction activity under the terms and conditions imposed by EPA's NPDES storm water general permit issued for use in the state of Washington. Your facility's NPDES storm water permit rumber is WAROOAl7F.

EPA's storm water general permit requires certain storm water pollution prevention and control measures, possible monitoring and reporling, and anrual inspections. Among the conditions and requirements of this permit, you must prepare and implement a pollution prevention plan (PPP) that is tailored to your industrial or construction site. Enclosed is a summary guidance document designed to assist you in the development and implementation of your PPP. The summary is organized according to the phases of the pollution prevent ion planning process. A sel of worksheets and an example of a pollution prevention plan are provided for your assistance. As a facility authorized to discharge under this storm water general permit, all terms and

$\stackrel{i}{i}$ conditions must be complied with to maintain coverage and avoid possible penalties.

The information included on your NOI indicated that you are required to submil monitoring data fo your facility's storm water discharges. Enclosed is monitoring and reporting guidance to assist you in the preparation of Discharge Monitoring Reports. If you have any questions regarding the specific monitoring requirements that apply

to your facility, please contact the EPA Regional office with permitting authority for your State. A 1 ist of EPA Regional offices with phone numbers and address is included at the end of the enclosed guidance.

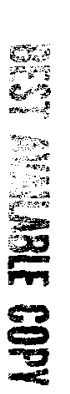

\section{FACILITY:}

Manford Site

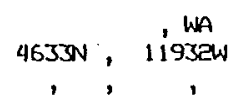

\section{OPERATOR:}

Us Dept of Energy-rl

Po Box 550

Richland, WA 99352-

If you have general questions concerning the storm water program, or need to obtain a copy of the permit, please call the Storm Water Hotline at (703) 821-4823. 
WHC-SD-EN-EV-021, Rev. I

APPENDIX G

EPCRA CERTIFICATION 


\section{EPCRA CERTIPICATION}

I, Lee K. Holder, a professional engineer with current registration in the State of Washington, have reviewed the document Hanford Site Pollution Prevention Plan, WHC-SDEN-EV-021; Revision 1, as revised July 291996 with respect the following facilities identified by the Westinghouse Hanford Company as being those subject to EPCRA Section 313: $183 \mathrm{KE}, 183 \mathrm{~N}, 283 \mathrm{KE}$, and $283 \mathrm{~W}$, and 315 . Having examined these facilities, and being familiar with the provisions of the NPDES General Permit for Storm Water Discharges Associated with Industrial Activity (Federal Register, Vol. 57, No. 175, September 9, 1992, pp. 41304 et. seq.), attest that, with respect EPCRA stormwater requirements for these facilities, this stormwater pollution prevention plan has been prepared in accordance with good engineering practices,

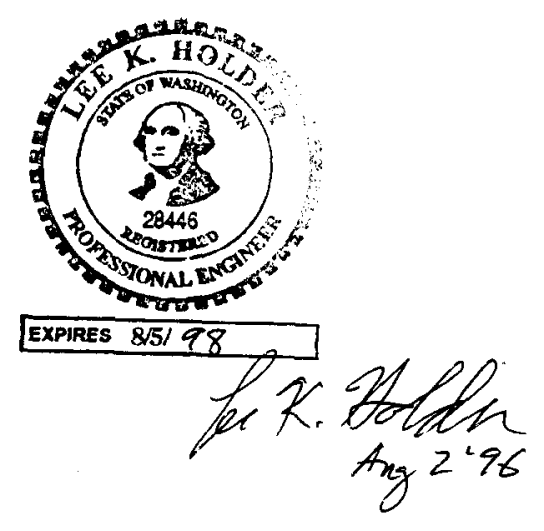




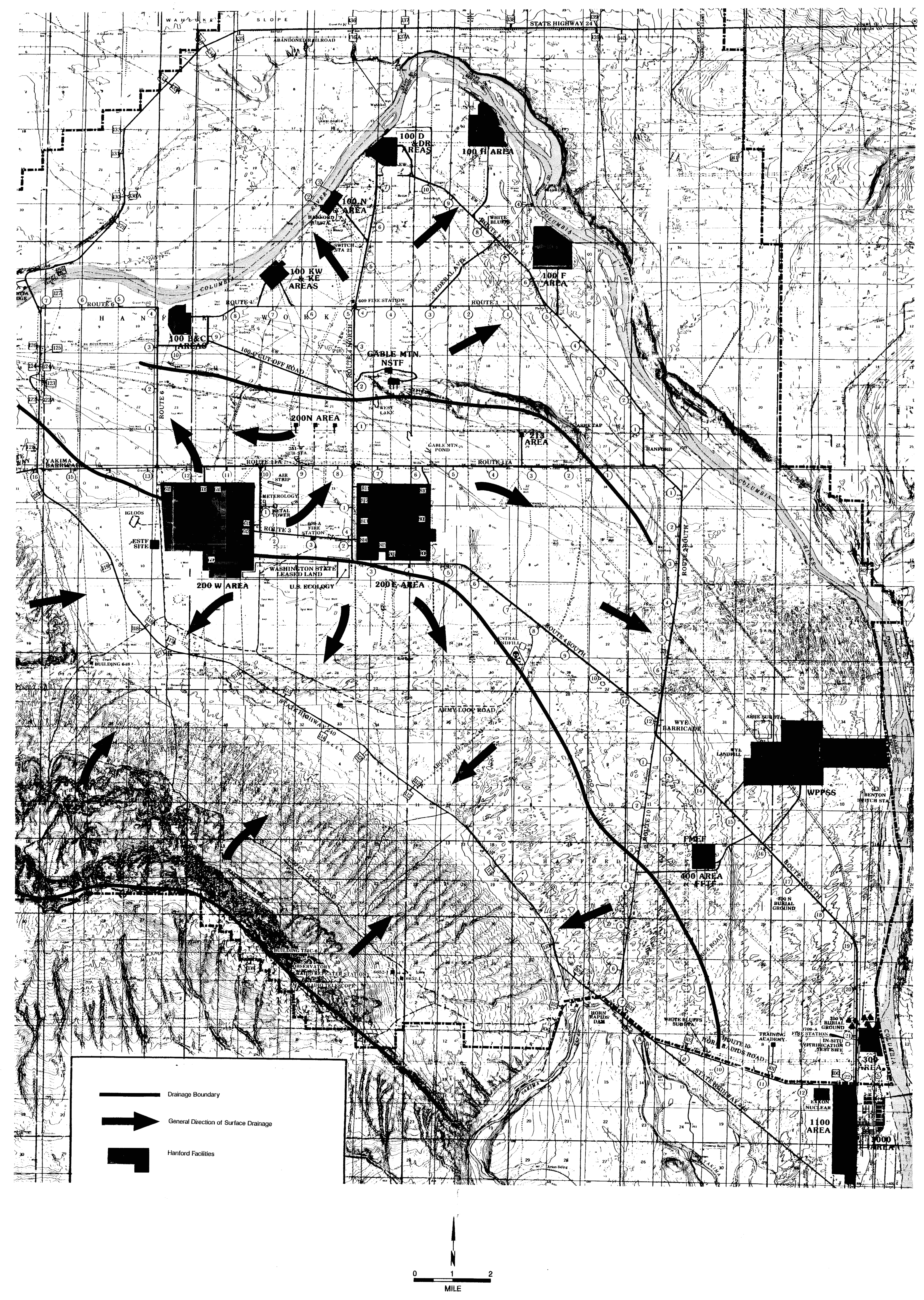


WHC-SD-EN-EV-021, Rev. 1

9/96

\section{DISTRIBUTION}

J. Wilkinson

Confederated Tribes of the Umatilla

Indian Nation

P. O. Box 638

Pendleton, Oregon 97801

D. Powaukee

Nez Perce Tribe

P. O. Box 365

Lapwai, Idaho 93540

R. Jim, Manager

Environmental Restoration/

Waste Management Program

Yakama Indian Nation

P. O. Box 151

Toppenish, Washington 98948

ONSITE

U.S. Department of Energy,

Richland Operations Office

J. M. Bruggeman

$\mathrm{H} 0-12$

R. N. Krekel

A5-15

P. M. Pak

$\mathrm{HO}-12$

J. E. Rasmussen

A5-15

Betchel Hanford Team

R. G. Egge

T7-05

M. E. Greenidge

X5-54

M.C. Hughes

H0-09

R.J. Landon

Ho- 18

P. J. Mackey

H0-09

J. J. McGuire

$\times 5-53$

L. A. Mihalik

H9-12

J. P. Zoric

X5-57 


\section{WHC-SD-EN-EV-021, Rev. 1 \\ 9/96}

DISTRIBUTION (cont)

Pacific Northwest National Laboratory

T. J. Lazarski

P7-79

B. P. Atencio (3)

P7-79

Westinghouse Hanford Company

C. DeFigh-Price

X3-79

L. P. Diediker

H6-36

G.S. Hunacek, Jr

X3-79

N. M. Menard

H6-24

C. J. Perkins

X5-57

D. J. Watson

X3-79

B. D. Williamson

B3-15

Central Files

A3-88 